Lucas Gonçalves Dias Mendonça

\title{
DESENVOLVIMENTO DE UM MICRO-TRANSDUTOR ACÚSTICO CAPACITIVO
}

Tese apresentada à Escola Politécnica da Universidade de São Paulo para obtenção do Título de Doutor em Engenharia Mecânica. 
Lucas Gonçalves Dias Mendonça

\section{DESENVOLVIMENTO DE UM MICRO-TRANSDUTOR ACÚSTICO CAPACITIVO}

Tese apresentada à Escola Politécnica da Universidade de São Paulo para obtenção do Título de Doutor em Engenharia Mecânica.

Área de concentração:

Engenharia de Controle e Automação Mecânica

Orientador:

Prof. Dr. Ricardo Cury Ibrahim 
FICHA CATALOGRÁFICA

Mendonça, Lucas Gonçalves Dias

Desenvolvimento de um micro-transdutor acústico capacitivo / L.G.D. Mendonça. -- ed. rev. -- São Paulo, 2014.

$84 \mathrm{p}$.

Tese (Doutorado) - Escola Politécnica da Universidade de São Paulo. Departamento de Engenharia Mecatrônica e de Sistemas Mecânicos.

1.Sistemas microeletromecânicos 2.Eletrostática 3.Sensores eletromecânicos I.Universidade de São Paulo. Escola Politécnica. Departamento de Engenharia Mecatrônica e de Sistemas Mecânicos II.t. 
a minha família e a minha namorada que sempre me incentivam e apoiam nos momentos difíceis... 


\section{Agradecimentos}

Ao Conselho Nacional de Desenvolvimento Científico e Tecnológico (CNPq) pelo apoio financeiro.

Ao Laboratório de Sistemas Integráveis da Escola Politécnica da USP (LSI-EPUSP) pelo uso de instalações e equipamentos.

Ao Laboratório de Microfabricação do Brazilian Nanotechnology National Laboratory (LNNano) pelo uso de instalações e equipamentos.

Ao Departamento de Engenharia Mecatrônica e de Sistemas Mecânicos pelo uso das instalações.

Ao Prof. Dr. Ricardo Cury Ibrahim pela orientação e incentivo.

Ao Prof. Dr. Delson Torikai e Prof. Dr. Nilton Itiro Morimoto por discussões que contribuíram muito para este trabalho.

A Professores, amigos, colegas e familiares que de alguma forma contribuíram para minha formação e/ou para o desenvolvimento desse trabalho. 


\section{Resumo}

Neste trabalho é proposto um dispositivo MEMS do tipo micro-transdutor acústico capacitivo, CMUT (sigla em inglês - Capacitive Micromachined Ultrasonic Transducer). Em vez de usar piezoeletricidade, o CMUT tem um array de capacitores,onde cada capacitor possui um eletrodo inferior fixo, uma cavidade e o eletrodo superior composto de uma placa flexível. Quando submetida a uma tensão CC adequada, a placa se deflete se aproximando do eletrodo inferior devido à força eletrostática. Assim a placa fica tensionada podendo vibrar quando exitada por uma tensão CA. Neste caso o CMUT opera como emissor de ondas acústicas. A placa também pode ser excitada por uma onda acústica agindo em sua superfície. Neste caso o dispositivo opera como sensor. Uma das contribuições desse trabalho é o processo de fabricação simplificado com o uso do fotorresiste SU-8 como parte da estrutura do dispositivo. Sua facilidade de processamento e suas propriedades físicas Ihe conferem estabilidade e rigidez adequadas para tal fim. Foram realizadas modelagens e simulações analíticas e computacionais do comportamento da placa. Os resultados auxiliaram no melhor entendimento do comportamento do dispositivo sob tensão mecânica devido a uma carga ou uma tensão de polarização. Esses resultados também auxiliaram na definição de parâmetros iniciais do processo de fabricação. Durante o processo de fabricação, foram realizados diversos testes a fim de se encontrar o processo mais adequado à infraestrutura disponível. No processo escolhido, a base do dispositivo é fabricada num substrato de vidro com eletrodos inferiores de alumínio depositados por evaporação. Os pilares são fabricados em SU-8, depositado por spin coatting. A placa é colada posteriormente utilizando-se fotorresiste AZ. O AZ é depositado sobre um pedaço de folha de cobre ou alumínio. As duas partes são colocadas em contato e para promover a colagem é aplicada pressão durante a cura. As amostras foram caracterizadas eletricamente utilizando-se um medidor de impedância RCL. Foram levantadas curvas de impedância, capacitância e ângulo de fase em função da frequência $(1 \mathrm{kHz}$ a $1 \mathrm{MHz}$ ). Além do sinal CA utilizado pelo instrumento durante a medição foi aplicado um nível CC que variou conforme as dimensões dos protótipos. Também foram levantadas curvas de impedância, capacitância e ângulo de fase em função de uma carga mecânica aplicada. Para valores de polarização mais elevados, foram montados circuitos específicos. Estes circuitos são capazes de polarizar o CMUT, aplicar um sinal CA para medição e proteger demais componentes e instrumentos dos aparatos de medição. O dispositivo respondeu bem a aplicação de carga mecânica, excitação por sinal CA e excitação com onda mecânica. Os resultados mostraram que o dispositivo apresenta bom potencial para ser aplicado na análise de fluidos. 


\section{Abstract}

This work presents a new process to fabricate an acoustic micro transducer to be used as a microsensor or a microactuator. The acoustic transducers are based on the electrostatic effect and consist on arrays of microfabricated capacitors. Such devices are commonly referred as CMUT, Capacitive Micromachined Ultrasonic Transducer. The bottom electrode (evaporated aluminum) of each capacitor is fixed on the surface of glass substrate, while the top electrode is a thin plate structure of copper or aluminum suspended on a cavity surrounded by posts. Since the top electrode is flexible, it bends toward the bottom electrode when a DC bias is applied. In this way, the top electrode can be forced to vibrate using an AC signal to be used as an acoustic wave emitter. Conversely, an ultrasound receiver is achieved as the measured capacitance changes when the DC biased top electrode moves following an external acoustic wave pressure. An innovation of this work is the use of the photoresist SU-8 to fabricate the post structures surrounding the cavities of the capacitive micro transducers. Its relatively simple processing steps and adequate mechanical properties make the SU-8 a convenient choice as an inexpensive structural material. The bottom part of the device is prepared on a glass substrate using an aluminum layer evaporated and etched to form the bottom electrodes. Then, SU-8 is spin coated, baked and etched adequately to form the posts surrounding the cavities. The top part is prepared by simply spinning an AZ-type photoresist on aluminum or copper plate. Finally, both halves are bonded under pressure on a hot plate. Several modeling and simulation analyses were performed in order to estimate the working performance of the micro transducers. The results of simulations helped to define the initial parameters and materials for the fabrication process. Samples submitted to a DC bias were initially characterized using an RCL meter in order to infer impedance, capacitance and phase angle behavior as a function of frequency (from $1 \mathrm{kHz}$ to $1 \mathrm{MHz}$ ). Protection circuits were used in order to test CMUTs with high DC bias. These circuits allow to apply high DC bias, and an $A C$ signal while other measuring equipments are protected. The device responded to application of mechanical loading, excitation by an AC signal and excitation by mechanical wave as well. The results showed that the device has good potential to be applied to the analysis of fluids. 


\section{Sumário}

\section{Lista de Figuras}

\section{Lista de Tabelas}

\section{Lista de Abreviaturas}

1 Introdução 1

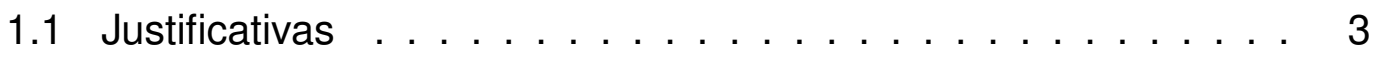

1.2 Objetivos $\ldots \ldots \ldots \ldots \ldots \ldots \ldots \ldots \ldots \ldots$

2 Conceitos de Processos e Materiais para CMUT 5

2.1 Processos Utilizados em Microfabricação $\ldots \ldots \ldots$

2.1 .1 Fotolitografia $\ldots \ldots \ldots \ldots \ldots \ldots \ldots$

2.1 .2 Evaporação Térmica . . . . . . . . . . . . . . 6

2.1 .3 Corrosão . . . . . . . . . . . . . . . 6

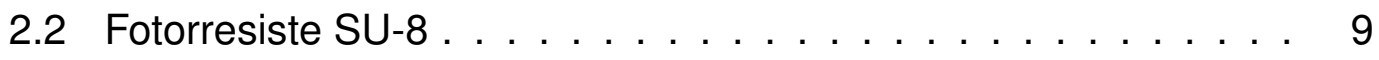

3 Conceitos de Ultrassom e Piezoeletricidade 11

3.1 Ultrassom . . . . . . . . . . . . . . . . . 11

3.1.1 Medição de Propriedades de Materiais . . . . . . . . 12

3.1 .2 Uso na Área Médica . . . . . . . . . . . . . . . . . . . 12

3.1.3 Medições de Distâncias . . . . . . . . . . . . . . . 12

3.1.4 Definições Básicas . . . . . . . . . . . . . . . . . . 13

3.1.5 Grandezas Quantitativas da Onda . . . . . . . . . . 13

3.1.6 Elasticidade, Tensão e Deformação . . . . . . . . . 15 
3.1.7 Módulo de Elasticidade . . . . . . . . . . . . . . 15

3.1 .8 Impedância Acústica . . . . . . . . . . . . . . 16

3.1.9 Onda Mecânica de Corpo ou Volume . . . . . . . . . . 17

3.1.10 Interação da Onda com um Meio Elástico . . . . . . . . 17

3.1.11 Utilização de Ondas em Meios Líquidos . . . . . . . . . 18

3.2 Piezoeletricidade . . . . . . . . . . . . . . . . . . . 19

4 Microtransdutores $\quad 21$

4.1 CMUTs e Alguns Métodos de Fabricação . . . . . . . . . . . 21

4.2 Aplicações para CMUTs . . . . . . . . . . . . . . . . . 24

5 Modelagens e Simulações $\quad 25$

5.1 Acoplamento Eletro-Mecânico . . . . . . . . . . . . . . 26

5.1 .1 Modelo Simplificado . . . . . . . . . . . . . . . 27

5.2 Materiais para CMUT . . . . . . . . . . . . . . . . 29

5.3 Modelagem Analítica . . . . . . . . . . . . . . . . . 30

5.4 Modelagem Computacional . . . . . . . . . . . . . . . . 31

5.5 Resultados de Simulações Analíticas . . . . . . . . . . . . 32

5.6 Resultados de Simulações Computacionais . . . . . . . . . . . 33

6 Fabricação $\quad 35$

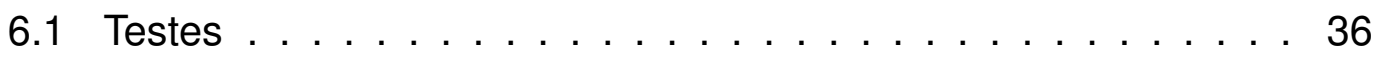

6.1.1 Fabricação por Camada Sacrificial . . . . . . . . . . 37

6.2 Fabricação por Colagem . . . . . . . . . . . . . . . 38

6.2.1 Fabricação da Base . . . . . . . . . . . . . . . . . 39

6.2 .2 Colagem da Placa . . . . . . . . . . . . . . . . . 39

6.2.3 Protótipos com Placas de Cobre . . . . . . . . . . . 40

6.2.4 Protótipos com Placas de Alumínio . . . . . . . . . . . . 41

6.3 Considerações sobre processo de fabricação . . . . . . . . . . 41 
7 Procedimentos de caracterizações 43

7.1 Medições de propriedades dielétricas . . . . . . . . . . 43

7.2 Montagens para caracterizações elétricas do CMUT . . . . . . . 43

7.3 Montagens para medições com tensão de polarização . . . . . . 44

7.3.1 Piezo emissor e CMUT receptor . . . . . . . . . . . 46

7.3.2 Varredura de frequência usando tensão de polarização 46

8 Resultados e Discussões 49

8.1 Resultados da fabricação . . . . . . . . . . . . . . . . . . 49

8.2 Resultados de medições $\mathrm{RCL} \ldots \ldots$. . . . . . . . . . . . 50

8.3 Resultados de medições utilizando circuitos adicionais . . . . . . 58

8.3.1 Resultados de varreduras com tensão de polarização . . 59

Conclusões

$\begin{array}{ll}\text { Sugestões para Trabalhos Futuros } & 67\end{array}$

$\begin{array}{ll}\text { Artigos publicados } & 68\end{array}$

$\begin{array}{ll}\text { Referências } & 69\end{array}$ 


\section{Lista de Figuras}

1.1 Estrutura de um CMUT. . . . . . . . . . . . . . . . . . . 1

1.2 Operação do CMUT como emissor e como receptor. . . . . . . . 2

3.1 Onda senoidal $\ldots \ldots \ldots \ldots \ldots$

3.2 Material piezoelétrico . . . . . . . . . . . . . . 19

4.1 Processo de fabricação de CMUT por wafer bonding utilizado por Ergun et al. (2005) . . . . . . . . . . . . . . . . . . . . 22

5.1 CMUT com eletrodo superior em forma de placa. . . . . . . . . 25

5.2 Modelo representando a força de mola da placa. . . . . . . . . 26

5.3 Representação de acoplamento eletro-mecânico genérico. Adaptado de Hunt (1954) . . . . . . . . . . . . . . . . . . . . 26

5.4 Modelos utilizados na modelagem analítica (a) para placa circular, (b) para placa retangular (YOUNG; BUDYNAS, 2002). . . . 31

5.5 Exemplo de modelo utilizado na simulação do comportamento da placa submetida a uma tensão CC . . . . . . . . . . . . 32

5.6 Deflexões obtidos para diferentes tensões de polarização aplicadas . . . . . . . . . . . . . . . . . . . . 34

6.1 Processo de fabricação de CMUTs com placa de cobre por colagem. . . . . . . . . . . . . . . . . . 40

6.2 Processo de fabricação de CMUTs com placa de alumínio por colagem. . . . . . . . . . . . . . . . . 41

7.1 Esquema de ligação do CMUT para operação como emissor. . . 45

7.2 Amostras de CMUTs presas a um suporte de placa de circuito impresso. . . . . . . . . . . . . . . . . . 45

7.3 Circuito amplificador utilizado para CMUT em modo receptor. . . 47 
7.4 Aparato utilizando transdutor piezoelétrico como emissor e CMUT como receptor. . . . . . . . . . . . . . . . . . . 47

7.5 Circuito clipper utilizado para polarizar CMUT e proteger medidor RCL. . . . . . . . . . . . . . . . . . . . . . 48

8.1 Protótipo de CMUT com placas de cobre. . . . . . . . . . . 51

8.2 Protótipo de CMUT com placas de alumínio. . . . . . . . . . 51

8.3 Curva de impedância em função da frequência para CMUT com placas de cobre. . . . . . . . . . . . . . . . . 51

8.4 Curva de capacitância em função da frequência para CMUT com placas de cobre. . . . . . . . . . . . . . . . 52

8.5 Curva do ângulo de fase em função da frequência para CMUT com placas de cobre. . . . . . . . . . . . . . . 52

8.6 Curva de impedância em função da frequência para CMUT com placas de alumínio com cavidade de $5 \mu \mathrm{m}$. . . . . . . . . . 52

8.7 Curva de capacitância em função da frequência para CMUT com placas de alumínio com cavidade de $5 \mu \mathrm{m}$. . . . . . . . 53

8.8 Curva do ângulo de fase em função da frequência para CMUT com placas de alumínio com cavidade de $5 \mu \mathrm{m}$. . . . . . . . 53

8.9 Curva de impedância em função da frequência para CMUT com placas de alumínio com cavidade de $0,5 \mu \mathrm{m}$. . . . . . . . . 54

8.10 Curva de capacitância em função da frequência para CMUT com placas de alumínio com cavidade de $0,5 \mu \mathrm{m}$. . . . . . . 54

8.11 Curva do ângulo de fase em função da frequência para CMUT com placas de alumínio com cavidade de $0,5 \mu \mathrm{m}$. . . . . . . 55

8.12 Curva de variação da impedância em função de uma força aplicada para CMUT com placas de alumínio com cavidade de $5 \mu \mathrm{m} \ldots \ldots \ldots \ldots \ldots \ldots \ldots \ldots$

8.13 Curva de variação da capacitância em função de uma força aplicada para CMUT com placas de alumínio com cavidade de $5 \mu \mathrm{m} \ldots \ldots \ldots \ldots \ldots \ldots$ 
8.14 Curva variação do ângulo de fase em função de uma força aplicada para CMUT com placas de alumínio com cavidade de $5 \mu \mathrm{m} \ldots \ldots \ldots \ldots \ldots \ldots$

8.15 Curva de variação da impedância em função de uma força aplicada para CMUT com placas de alumínio com cavidade de $0,5 \mu \mathrm{m} \ldots \ldots \ldots \ldots \ldots \ldots$

8.16 Curva de variação da capacitância em função de uma força aplicada para CMUT com placas de alumínio com cavidade de $0,5 \mu \mathrm{m} \ldots \ldots \ldots \ldots$. . . . . . . . . . . . . . 57

8.17 Curva variação do ângulo de fase em função de uma força aplicada para CMUT com placas de alumínio com cavidade de $0,5 \mu \mathrm{m} \ldots \ldots \ldots \ldots$. . . . . . . . . . . . 57

8.18 Curvas de impedância para meio arranjo de CMUTs com placas de alumínio de $1000 \mu \mathrm{m}$ de diâmetro.

8.19 Curvas de capacitância para meio arranjo de CMUTs com placas de $1000 \mu \mathrm{m}$ de diâmetro.

8.20 Curvas de ângulo de fase para meio arranjo de CMUTs com placas de alumínio de $1000 \mu \mathrm{m}$ de diâmetro.

8.21 Curvas de impedância para arranjo inteiro de CMUTs com placas de alumínio de $600 \mu \mathrm{m}$ de diâmetro.

8.22 Curvas de capacitância para arranjo inteiro de CMUTs com placas de alumínio de $600 \mu \mathrm{m}$ de diâmetro.

8.23 Curvas de ângulo de fase para arranjo inteiro de CMUTs com placas de alumínio de $600 \mu \mathrm{m}$ de diâmetro.

8.24 Curva de impedância para arranjo de CMUTs com placas de cobre de $500 \mu \mathrm{m}$ de diâmetro.

8.25 Curva de capacitância para arranjo de CMUTs com placas de cobre de $500 \mu \mathrm{m}$ de diâmetro.

8.26 Curva de ângulo de fase para arranjo de CMUTs com placas de cobre de $500 \mu \mathrm{m}$ de diâmetro. 


\section{Lista de Tabelas}

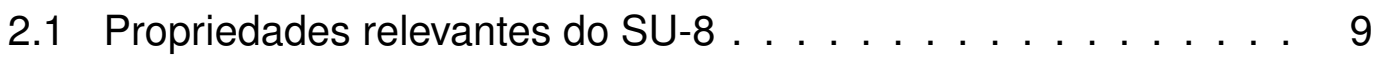

5.1 Propriedade de alguns materiais utilizados nas modelagens . . 29

5.2 Valores das constantes $\beta_{1}, \beta_{2}$ e $\alpha \ldots \ldots \ldots \ldots \ldots \ldots$

5.3 Resultados das simulações analíticas com placas de cobre . . . 33

5.4 Resultados das simulações analíticas com placas de alumínio . 33

5.5 Parâmetros utilizados nas simulações computacionais . . . . . 33

8.1 Dimensões das amostras fabricadas e caracterizadas. . . . . . . 50 


\section{Lista de Abreviaturas}

AZ Fotorressiste positivo de uso comum em microeletrônica produzido

Cls Circuitos Integrados

CMUT do inglês, Capacitive Micromachined Ultrasonic Transducers

CVD do inglês, Chemical Vapor Deposition

DRIE do inglês, Deep Reactive-ion etching

LNLS Laboratório Nacional de Luz Síncrotron

LNNANO Laboratório Nacional de Nanotecnologia

LPCVD do inglês, Low-Pressure Chemical Vapor Deposition

LSI Laboratório de Sistemas Integráveis

LTO do inglês, Low-temperature Oxide

MEMS do inglês, Micro-electro-mechanical systems

MIT Massachusetts Institute of Technology

PECVD do inglês, Plasma-Enhanced Chemical Vapor Deposition

RCL Relativo a Resistência, Capacitância, Indutância

RIE do inglês, Reactive-ion etching

SU8 Fotoresiste negativo utilizado em MEMS produzido pela Microchem. Diponível em diferentes séries de acordo com a espessura desejada

uv Ultravioleta 


\section{Introdução}

Recentemente um tipo de dispositivo MEMS vem sendo estudado por diversos pesquisadores. Trata-se do Transdutor Ultrassônico Capacitivo que é mais conhecido pela sigla em inglês, CMUT (Capacitive Micromachined Ultrasonic Transducer). O CMUT é uma espécie de transdutor que provoca ou detecta uma excitação ultrassônica assim como transdutores piezoelétricos. Entretanto, em vez de usar piezoeletricidade, o CMUT tem seu princípio de operação baseado em forças eletrostáticas (HALLER; KHURI-YAKUB, 1994; DEMIRCI et al., 2004; HUANG; HAEGGSTROM; BAYRAM, 2003; BAYRAM et al., 2003; ZHUANG; MEMBER; WYGANT, 2009; CHANG et al., 2006; BUHRDORF et al., 2003; CHIOU et al., 2007). Geralmente o dispositivo é composto de um arranjo de elementos capacitivos. Cada elemento possui um eletrodo inferior rígido, uma cavidade (em muitos casos selada em vácuo) e uma placa flexível contendo o eletrodo superior (fig. 1.1).

O layout capacitivo do dispositivo permite o acúmulo de cargas nos eletrodos caso haja uma diferença de potencial entre os mesmos. Com isso há formação de campo elétrico entre as placas gerando forças de atração. Como o eletrodo superior é uma placa flexível, uma diferença de potencial adequada
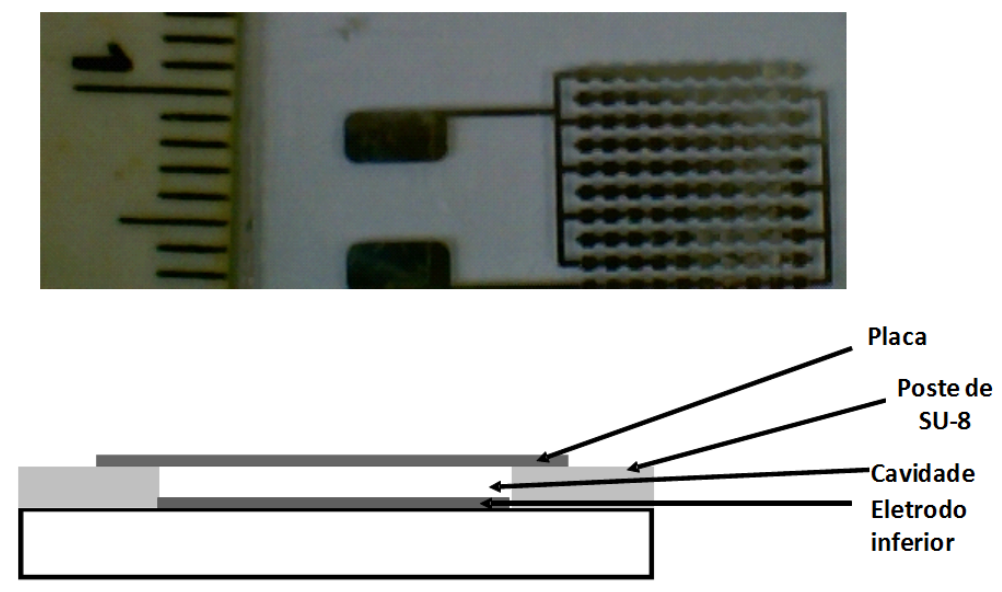

Figura 1.1: Estrutura de um CMUT. 

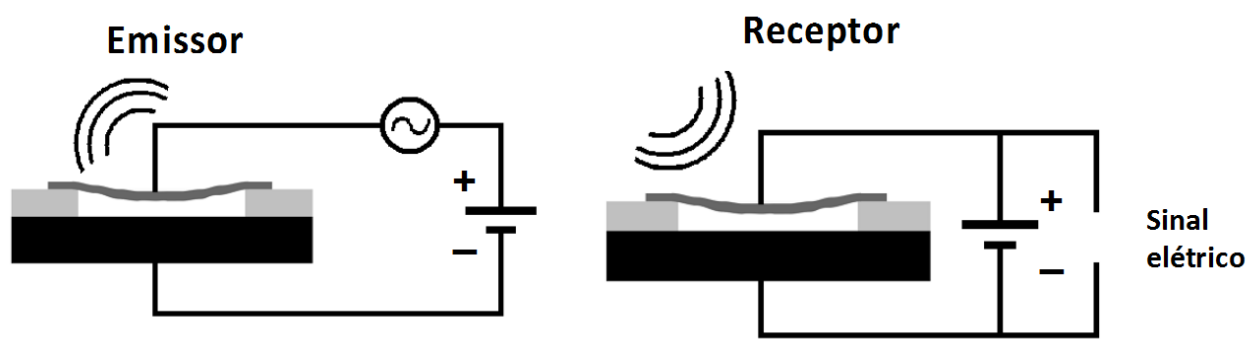

Figura 1.2: Operação do CMUT como emissor e como receptor.

é capaz de faze-la fletir (curvar-se) em direção ao eletrodo inferior. Assim, se utilizada uma tensão alternada de amplitude e frequência adequadas, a placa pode vibrar em uma frequência definida pelo sinal de entrada. Uma voltagem contínua CC também deve ser utilizada para aproximar mais a placa do eletrodo inferior (polarização). No sentido inverso de operação, essa placa pode sofrer uma excitação física devido a uma vibração causada por uma onda acústica e apresentar uma diferença de potencial em seus terminais. Neste caso o CMUT pode ser usado como sensor acústico (fig. 1.2).

Neste trabalho é proposto um micro-transdutor do tipo CMUT com algumas particularidades que o diferem de outros CMUTs já apresentados na literatura. Os métodos de fabricação utilizados são mais simples, exigindo apenas equipamentos básicos de sala limpa e processos a baixas temperaturas. Não são exigidos equipamentos de CVD, epitaxia e plasma, por exemplo. Em sua estrutura é utilizado o fotorresiste SU-8, que é comumente usado como material estrutural devido a suas propriedades físicas. A aplicação proposta para o dispositivo é na análise de fluídos (líquido ou gás) através da recepção de uma onda vinda do fluído. As partes móveis são imersas no fluido e o movimento amortecido será relacionado com propriedades desse fluído. Assim o dispositivo tem potencial de ser usado em conjunto com um sensor capacitivo desenvolvido em trabalhos anteriores no sentido de superar suas limitações (MENDONÇA, 2008). Há outras possibilidades como utilizar o CMUT como atuador acústico para uso médico ou industrial.

Atualmente, na maioria das pesquisas, os CMUTs são projetados para operar em altas frequências (ultrassônicas) pois geralmente o objetivo é a utilização na área médica. Neste trabalho, entretanto, a frequência de operação não é limitada a faixas acima do audível (ultrassônica). São exploradas ondas acústicas em frequências de centenas de hertz $\mathrm{Hz}$ ) a 1 mega hertz $(1 \mathrm{MHz})$. 
Transdutores ultrassônicos baseados no efeito piezoelétrico foram desenvolvidos há várias décadas atrás para diversas aplicações (CADY, 1964; JAFFE; COOK; JAFFE, 1971; IKEDA, 1990; JUN et al., 2008): sonar, caracterização de propriedades de materiais (constante elástica, densidade, viscosidade, etc.), acelerômetro, diagnóstico médico, motor, microfone, etc. Entretanto, os transdutores ultrassônicos baseados no efeito piezoelétrico apresentam algumas desvantagens em sua utilização (TÖRNDAHL; AL, 2002; ANDERSON et al., 2005). Após um curto tempo de operação a cerâmica piezoelétrica se aquece, alterando suas características de operação. Além disso, toda cerâmica piezoelétrica sofre o efeito de despolarização após um certo período de uso e dependendo das condições de operação. Essas alterações resultam em perda de precisão de posicionamento no caso de uso como atuador. Outra dificuldade encontra-se no processo de fabricação devido à dificuldade de obtenção de filmes piezoelétricos de boa qualidade para uso em atuadores.

O micro-transdutor capacitivo proposto oferece as seguintes vantagens se comparado aos transdutores piezoelétricos:

- sofre menor aquecimento durante operação;

- não sofre efeitos característicos de cerâmicas piezoelétricas como despolarização, envelhecimento, e histerese ferroelétrica;

- apresenta fabricação relativamente simples com as técnicas comuns de microfabricação .

\subsection{Justificativas}

Transdutores ultrassônicos são de grande importância em diversas áreas de interesse como medicina, industria, e engenharia. Atualmente esses dispositivos utilizam-se basicamente de cerâmicas piezoelétricas. Entretanto esses materiais sofrem diversos problemas como histerese ferrelétrica, despolarização, limite máximo de temperatura de uso e acoplamento fraco com meios fluídos.

Os Sistemas Micro-Eletromecânicos (MEMS) estão cada vez mais presentes na vida das pessoas com aplicações em diversas áreas da engenharia (ALLEN, 2005). Tradicionalmente são mais populares entre os grupos de microeletrônica e mecânica-mecatrônica. Os processos de 
fabricação dos dispositivos baseiam-se nas técnicas da microeletrônica (MADOU, 2002), tendo o silício como o principal material utilizado. A tendencia de se miniaturizar cada vez mais os dispositivos permite uma integração cada vez maior entre componentes eletrônicos, mecânicos, ópticos etc. Neste aspecto dispositivos capacitivos tendem a apresentar maior integrabilidade com componentes elétricos se comparados a dispositivos piezoelétricos. Dispositivos capacitivos apresentam fabricação mais simples e não sofrem efeitos como despolarização. Além da questão da integrabilidade, a redução de custos é de interesse em qualquer setor produtivo. Assim o CMUT proposto neste trabalho, com processo de fabricação relativamente barato e simplificado apresenta bom potencial na área de ultrassom para avaliação de fluídos.

\subsection{Objetivos}

Este trabalho tem por objetivo propor um micro-transdutor baseado no efeito capacitivo usando ar ou vácuo como dielétrico. O trabalho inclui projeto, modelagem, fabricação de protótipos e caracterizações do dispositivo. A etapa de modelagem e simulações envolve modelagem analítica e análises computacionais usando software de elementos finitos. A fabricação consiste em usar métodos simples de microfabricação como ponto de partida. Esses métodos são então, adaptados as necessidades da fabricação do dispositivo. O dispositivo utiliza polímeros como parte de sua estrutura definitiva. Deve ser fabricado a baixas temperaturas usando equipamentos básicos de sala limpa. Não são utilizados processos como CVD, oxidação térmica e difusão. Entretanto devem ser utilizados processos adicionais pouco comuns à microfabricação. O fotorresiste SU-8 será utilizado como parte estrutural do dispositivo. Este material é utilizado por apresentar propriedades adequadas à estruturas permanentes; por ter processo simples de deposição; por ser fotossensível, facilitando sua litografia etc. 


\section{Conceitos de Processos e Materiais para CMUT}

A seção 2.1 descreve sucintamente alguns processos de microfabricação utilizados na fabricação de CMUTs. A seção 2.2 descreve algumas propriedades do fotorresiste SU8-8 de grande relevância para este trabalho.

\subsection{Processos Utilizados em Microfabricação}

Os processos descritos a seguir são usados em microeletrônica para fabricação de Circuitos Integrados (Cls) e em MEMS incluindo fabricação de CMUTs. Alguns desses processos foram empregados na fabricação do CMUT proposto neste trabalho. Adaptações foram realizadas para se obter os protótipos. As etapas da fabricação e adaptações realizadas são apresentadas no capítulo 6 .

\subsubsection{Fotolitografia}

É o processo pelo qual os padrões dos componentes são transferidos para o substrato ou uma camada. É depositado sobre o substrato ou camada, um polímero fotossensível chamado fotorresiste. O fotorresiste é depositado na forma líquida e é espalhado utilizando-se um spinner. A espessura está relacionada à viscosidade e à velocidade de rotação. A amostra é aquecida em uma chapa quente (hotplate) para que o solvente do fotorresiste se evapore. Este processo é chamado cura ou bake (termo em inglês). Então o fotorresiste é coberto por uma máscara contendo os padrões geométricos dos dispositivos. Essa máscara tem regiões claras e escuras para permitir passagem de luz somente nas regiões de interesse. Em seguida o fotorresiste é exposto à luz ultravioleta, que causa uma reação polimerizando 
ou tornando-o solúvel ao seu revelador. Em seguida, o fotorresiste é revelado, utilizando-se uma solução, para que permaneça somente nas regiões de interesse. Caso o fotorresiste seja do tipo positivo, as regiões que são expostas à luz uv se dissolvem. Caso seja negativo, as regiões expostas permanecem. Assim o fotorresiste serve como máscara para o processo subsequente (corrosão por exemplo) e depois é removido.

\subsubsection{Evaporação Térmica}

Evaporação térmica é um método físico de deposição de filmes finos. É realizado em uma câmara específica ligada a um sistema de vácuo. Antes do processo é feito vácuo na câmara até que se atinja a pressão de trabalho. Durante o processo de deposição, o material a ser depositado é aquecido e sublimado por um filamento ou cadinho por onde passa uma corrente elétrica. O material se condensa novamente por toda a câmara inclusive sobre a amostra em que se deseja depositar o material formando o filme. Este processo foi utilizado para a deposição de alumínio para a formação dos eletrodos inferiores do CMUT.

Maiores detalhes desses métodos podem ser vistos em Madou (2002).

\subsubsection{Corrosão}

Processos de corrosão são geralmente realizados após a revelação de fotorresiste na litografia. Estes processos são usualmente divididos em dois tipos, corrosão úmida e a corrosão por plasma (FRANSSILA, 2004). Também é comum o uso do termo corrosão seca como oposto de corrosão úmida, esse termo é usualmente empregado para referir-se à corrosão por plasma. Entretanto há métodos de corrosão seca que não envolvem plasma. Tomando o exemplo do silício, a corrosão úmida se dá de acordo com a equação 2.1.

$$
\mathrm{Si}_{s}+2 \mathrm{OH}^{-}+2 \mathrm{H}_{2} \mathrm{O} \rightarrow \mathrm{Si}(\mathrm{OH})_{2}\left(\mathrm{O}^{-}\right)_{2(a q)}+2 \mathrm{H}_{2(g)}
$$

A corrosão por plasma se dá pela equação 2.2.

$$
\mathrm{SiO}_{2(s)}+\mathrm{CF}_{4(g)} \rightarrow \mathrm{SiF}_{4(g)}+\mathrm{CO}_{2(g)}
$$

Para que a corrosão ocorra existem três etapas principais. 
- transporte dos reagentes à superfície;

- reação na superfície;

- remoção dos produtos formados.

Se a corrosão não ocorrer, o problema deve estar em uma dessas etapas. O transporte pode estar sendo prejudicado de alguma forma, por exemplo um oxido nativo ou resíduos de algum processo anterior. Ou os produtos não se fizeram voláteis ou solúveis o bastante e se depositaram novamente na lâmina.

Ambos tipos de corrosão citados apresentam taxas de corrosão típicas variando entre 100 e $1000 \mathrm{~nm} / \mathrm{min}$. O limite inferior tem origem nos custos da fabricação. O limite superior se deve a degradação do resiste, temperaturas e considerações quanto a danos. O silício é um caso a parte podendo apresentar taxas de corrosão de até $20 \mu \mathrm{m}$. O silício pode ser corroído a esta taxa via úmida utilizando-se solução $H F$ : $\mathrm{NO}_{3}$ ou via plasma (DRIE) de $S F_{3} / C_{4} F_{8}$.

\section{Corrosão Úmida}

A corrosão úmida se divide em duas categorias, corrosão metálica, em que ocorre reação de transferência de elétron (eq. 2.3) e corrosão de isolante, com reação ácido-base (eq. 2.4).

$$
\begin{gathered}
M e_{(s)} \rightarrow M e_{(a q)}^{n+}+n e^{-} \\
\mathrm{SiO}_{2}+6 \mathrm{HF} \rightarrow \mathrm{H}_{S} i \mathrm{OF}_{6(a q)}+2 \mathrm{H}_{2} \mathrm{O}
\end{gathered}
$$

Reações tipo corrosão metálica têm taxa de reação limitada pela reação na superfície pois essa reação é lenta. Já corrosões de isolante têm reação rápida na superfície. Essas reações são limitadas pela disponibilidade de reagente.

Processos limitados pela reação na superfície possuem energia de ativação de 30 a $90 \mathrm{~kJ} / \mathrm{mol}$. A taxa cresce com o aumento da concentração de reagente e não é sensível a agitação.

Reações controladas por transporte apresentam energia de ativação de 4 
a $25 \mathrm{~kJ} / \mathrm{mol}$. A taxa desse tipo de reação aumenta com a agitação pois mais reagente é trazido para a superfície.

A corrosão úmida se divide basicamente em três variantes:

- banho, vaso com aquecimento e temperatura controlados onde a amostra é imersa na solução;

- spray, amostras colocadas em cabeça rotatória e bicos estacionários jogam reagente por spray;

- single-wafer, semelhante a spinner para fotorresiste, com reagente lançado por spray mas só de um lado da amostra.

As corrosões podem ter perfil isotrópico ou anisotrópico. A corrosão isotrópica se propaga para todas as direções tendo um formato esférico. Assim a corrosão nas direções laterais se dá na mesma proporção que a corrosão na vertical. Assim, esse tipo de corrosão não é indicado para se fazer estruturas finas.

Corrosão isotrópica é o perfil mais comumente encontrado. A maioria das soluções para corrosão úmida apresenta esse perfil, que também é encontrado em corrosão por plasma e corrosão seca. Na corrosão por plasma, o nível de isotropia pode ser controlado pelos parâmetros de corrosão podendo ser totalmente isotrópico a totalmente anisotrópico. A corrosão lateral pode ser compensada fazendo-se a máscara mais larga que a dimensão desejada para estruturas de campo claro e vice versa para estruturas de campo escuro. Esta estrategia funciona bem para estruturas isoladas, mas sua utilidade fica comprometida para arrays densos.

Corrosão úmida não é perfeitamente isotrópica, podendo ter inclinação íngreme ou suave dependendo dos parâmetros concentração e temperatura. A dificuldade no controle de corrosão aumenta com o aumento do número de camadas de filmes.

Geralmente, a corrosão lateral é indesejável. Entretanto, há ocasiões em que é necessária. É o caso se estruturas que necessitam de liberdade para se movimentar como cantilevers e membranas. Nestes casos a corrosão deve ser isotrópica e é necessário que haja corrosão lateral.

Quanto à corrosão úmida anisotrópica, esta ocorre quando as velocidades de corrosão são diferentes nos diferentes planos. Um exemplo é a corrosão 
Tabela 2.1: Propriedades relevantes do SU-8

\begin{tabular}{|cc|}
\hline Adesão $(\mathrm{mPa})$ silício/vidro/vidro e HMDS & $38 / 35 / 35$ \\
Temperatura de transição vítrea $\left({ }^{\circ} \mathrm{C}\right)$ & 210 \\
Condutividade térmica $(\mathrm{W} / \mathrm{mK})$ & 0,3 \\
Coef. expansão termica $(\mathrm{ppm} / \mathrm{K})$ & 52 \\
Limite de resitência mecânica $(\mathrm{MPa})$ & 60 \\
Deformação na ruptura $\left(\varepsilon_{b} \%\right)$ & 6,5 \\
Módulo de Young $(\mathrm{GPa})$ & 2,0 \\
Constante dielétrica $(@ 10 \mathrm{MHz})$ & 3,2 \\
\hline
\end{tabular}

anisotrópica de silício com $\mathrm{KOH}$. A corrosão no plano (100) é muito mais rápida que no plano (111). Assim é possível conseguir uma corrosão bastante anisotrópica.

O processo de corrosão foi utilizado basicamente para corroer alumínio e definir os eletrodos inferiores. A solução utilizada é $80 \mathrm{H}_{3} \mathrm{PO}_{4}+10 \mathrm{H}_{2} \mathrm{O}+$ $5 \mathrm{HNO}_{3}$.

\subsection{Fotorresiste SU-8}

O SU-8 é um fotorresiste negativo com alta razão de especto, insolúvel em água. Pode ser utilizado em diversas concentrações, o que resulta em diferentes faixas de espessura. Pode-se trabalhar com espessuras tão baixas quanto $0,5 \mu \mathrm{m}$ a espessuras da ordem de $100 \mu \mathrm{m}$. Pode ser comprado na concentração desejada para uma faixa determinada de espessura ou pode ser diluído para ser utilizado em espessuras mais baixas. Quando exposto à luz ultravioleta, o SU-8 se polimeriza tornando-se insolúvel a reveladores. Neste estado, o SU-8 é um material muito estável mecânica, química e termicamente (SAMEOTO; TSANG; PARAMESWARAN, 2007). A tabela 2.1 lista algumas propriedades relevantes do SU-8 fornecidas pelo fabricante.

Além das boas propriedades mecânicas, o material é biocompatível. Devido a essas propriedades que the conferem uma grande flexibilidade de aplicação, o SU-8 vem sendo largamente usado também como material estrutural na tecnologia MEMS. É utilizado em estruturas como micro-moldes e estruturas definitivas. A utilização do SU-8 é semelhante à de qualquer fotorresiste, é depositado com o auxilio de um spinner para espalhá-lo sobre a amostra e necessita de uma cura para remoção do solvente. Mas requer uma etapa de cura após a exposição, que é dispensável em outros fotorresistes. 
A espessura também pode ser controlada pela velocidade do spinner. A revelação e feita com revelador fornecido pelo fabricante. Após a revelação o SU-8 pode passar por uma etapa adicional de cura, o chamado hard bake. Esta etapa geralmente é opcional. Entretanto as propriedades do material são muito sensíveis à esta etapa. Após a revelação, uma estrutura em SU-8 está sob tensão mecânica. O hard bake pode aliviar essa tensão (MA et al., 2007). 


\section{Conceitos de Ultrassom e Piezoeletricidade}

Este capítulo trará alguns conceitos sobre ondas e ultrassom na seção 3.1 e piezoeletricidade na seção 3.2.

\subsection{Ultrassom}

Ondas mecânicas são consideradas ultrassônicas em frequências acima de $20 \mathrm{kHz}$. Muitas aplicações utilizam frequências na faixa de $20 \mathrm{kHz}$ a $10 \mathrm{MHz}$. Entretanto há aplicações que chegam a frequências de $5 \mathrm{GHz}$ (LEMPRIERE, 2002).

Em processos de manufatura, métodos ultrassônicos têm sido usados desde a década de 1940. As técnicas baseiam-se essencialmente em verificar o eco de um pulso em propagação. Os avanços da eletrônica nos anos 1960 e 1970 tornaram possível a medição da velocidade de propagação da onda com precisão. Nos anos 1970 e 1980, com a industria do silício foi criado o microscópio ultrassônico. Na área médica, os avanços passaram a permitir análises como escaneamento de fetos em gestantes e medição de fluxo sanguíneo em artérias.

Atualmente análises de ultrassom permitem detectar diversas patologias no corpo humano. Técnicas analisam variações de formato, tamanho, ou movimento de órgãos e presença de material anormal.

$\mathrm{Na}$ industria o uso mais comum de análises de ultrassom é na inspeção de peças fabricadas. Essas análises procuram por falhas como trincas em soldas, furos, porosidade, irregularidades em materiais compostos etc. As falhas no material interferem no sinal que retorna (eco) ao equipamento de medição. Um trinca, por exemplo, gera um eco adiantado e com baixa atenuação se comparado a um eco gerado pelo material regular. Uma região 
de baixa densidade, gera um eco atenuado e atrasado.

\subsubsection{Medição de Propriedades de Materiais}

A medição de propriedades elásticas de materiais pode ser realizada pelo tempo de propagação ou a velocidade da onda no material conhecendo-se as dimensões do objeto. No sentido oposto, se a velocidade do onda no material e outras propriedades do mesmo são conhecidas, é possível determinar suas dimensões.

\subsubsection{Uso na Área Médica}

Em ultrassonografia, principal uso na área médica, há dois métodos utilizados, o pulso-eco e o efeito Doppler. O método pulso-eco é utilizado para fazer um mapeamento de uma área do corpo ou um órgão. Utiliza-se equipamento com um transdutor ou um array de transdutores. Esse equipamento é passado sobre a área a ser analisada. O transdutor envia um pulso, que ao atingir o órgão, é refletido. O sinal recebido de volta (eco) é convertido em imagens através de software. A medição de movimentos como fluxo sanguíneo é realizada através do método doppler. Neste caso é usado um transdutor que fica fixo na pele em um ângulo adequado à propagação de ondas dentro do vazo sanguíneo. O sinal que retorna ao equipamento (eco) têm a frequência alterada pelo efeito doppler do fluxo sanguíneo.

\subsubsection{Medições de Distâncias}

Medições por ondas utilizam-se de suas propriedades mensuráveis, que são basicamente relacionadas ao tempo e a amplitude. O tempo de propagação pode ser utilizado para medir a velocidade da onda em um meio quando a distância percorrida é conhecida. De forma contrária pode ser usado para medir a distância se a velocidade é conhecida. A velocidade da onda pode ser usada para calcular a densidade de um material se as propriedades elásticas e o tipo de onda são conhecidos. Reciprocamente se a densidade é conhecida, pode-se calcular as propriedades elásticas. A amplitude de uma onda pode ser usada para determinar o amortecimento (absorção de energia) de um meio, o que é um indicativo da natureza do material. 


\subsubsection{Definições Básicas}

Nesta seção serão citadas alguma definições importantes no campo do ultrassom.

\subsubsection{Onda}

Onda é uma transição de movimento entre dois estados de um meio. O estado numa onda elástica é a tensão mecânica agindo no meio e sua velocidade. Uma onda elástica carrega mudanças na tensão mecânica e na velocidade. Há dois tipos de onda elástica, as ondas de corpo, que se propagam no interior de um objeto e onda de superfície, que se propaga perto da superfície.

\subsubsection{Forma de Onda}

Forma de onda é a sequência de movimentos que uma onda apresenta no tempo. Um exemplo típico é a onda senoidal, que é a mais simples matematicamente. Na realidade um sinal apresenta várias formas de onda, a excitação inicial (que frequentemente é suprimido), pulso-eco.

\subsubsection{Frente de Onda}

A frente de onda é a superfície formada pela onda que se propaga num meio. Depende do tipo de material do meio e da excitação. Para uma fonte puntiforme em um meio isotrópico e uniforme, por exemplo, uma onda se propaga em esferas crescentes ou decrescentes com a mesma velocidade em todas as direções. Em um meio anisotrópico, a onda se propaga em velocidades diferentes nas diferentes direções, distorcendo a frente de onda.

\subsubsection{Grandezas Quantitativas da Onda}

Geralmente, na prática uma onda não é uma oscilação de frequência única. Há na verdade uma combinação de oscilações senoidais de variadas frequências, amplitudes e fases. As diferentes frequências compõem o espectro da forma de onda. Sistemas de ultrassom geralmente utilizam ondas em que há uma frequência dominante. As grandezas quantitativas necessárias para descrever uma onda são fase, frequência e período; 


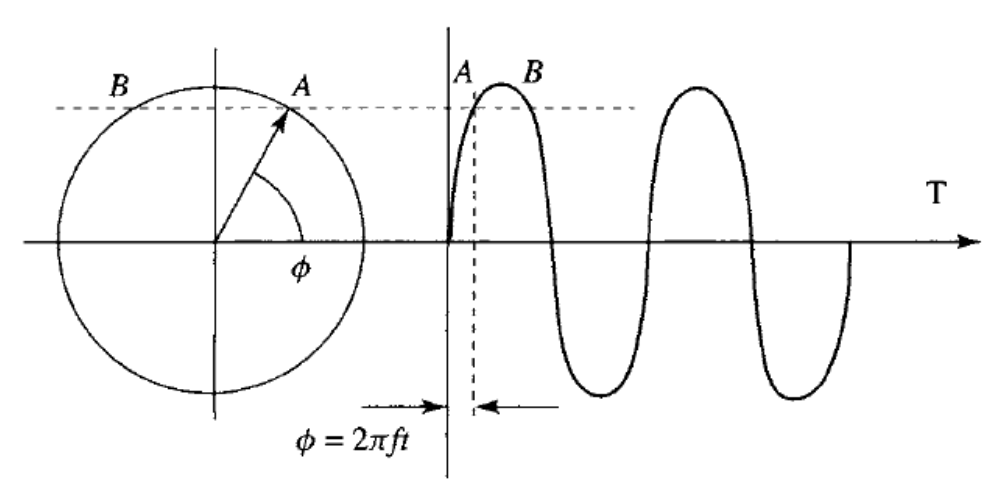

Figura 3.1: Onda senoidal

velocidade de onda, comprimento de onda e número de onda; amplitude de velocidade de partícula, e tensão mecânica.

Frequência $f$ é a taxa de oscilações por unidade de tempo. O tempo necessário para uma oscilação é o período $\tau$. Assim o período é o inverso da frequência $(\tau=1 / f)$. A onda da figura 3.1 pode ser expressa pela seguinte equação 3.1 .

$$
a(t)=A \sin \omega t
$$

onde $a(t)$ é a magnitude da onda em função do tempo t, $A$ é a amplitude e $\omega$ é a frequência angular sendo que $\omega=2 \pi f$. O ângulo de rotação em um certo instante $t$ é chamado fase, $\phi$, e é dado pela equação 3.2.

$$
\phi=2 \pi f t=\omega t
$$

O comprimento de onda $\lambda$ é a distância ocupada por um ciclo da onda em um instante $t$. O número de onda é o número de radianos em um ciclo $(k=2 \pi / \lambda)$. A mudança de fase $\phi$ sobre unidade de distância é dada por:

$$
\phi=k x=2 \pi x / \lambda
$$

A velocidade de onda $(c=\omega / k=f \lambda)$ descreve o progresso da onda e é determinada por forças de elasticidade e inércia. 


\subsubsection{Elasticidade, Tensão e Deformação}

Considera-se um meio elástico, aquele que se deforma reversivelmente sob ação de uma carga. Durante a carga e a descarga, há uma correspondência única entre a tenção e a deformação. Materiais simples como a maioria dos metais possuem elasticidade linear enquanto materiais como borracha possuem elasticidade não linear.

Considerando uma força aplicada sobre uma área, tensão mecânica é definida como a razão da força local por unidade de área. Uma força normal à superfície produz tensão também normal a essa superfície. Quando a força é tangente à superfície, a tensão é transversal. Devido às três direções de ambas as grandezas componentes da tensão (força e área) ela apresenta nove componentes, sendo seis independentes devido à simetrias.

Deformação mecânica é a deformação local por unidade de comprimento. Como as duas unidades são comprimento, trata-se de uma grandeza adimensional. Também apresenta seis componentes independentes pois a deformação é direcional.

Um meio elástico é dito isotrópico se a deformação é independente da direção da força aplicada. Caso a deformação dependa da direção da força aplicada, o material é dito anisotrópico.

\subsubsection{Módulo de Elasticidade}

Módulo de elasticidade ou constante elástica é a relação entre tensão e deformação na região linear. Quanto maior o módulo de elasticidade, maior a rigidez de um material. Tem a mesma unidade de tensão uma vez que a deformação é adimensional. Como deformação e tensão apresentam 6 componentes independentes cada (eqs. 3.4 e 3.5), haveriam 36 módulos de elasticidade (eq. 3.6). Entretanto, a conservação de energia determina que três sejam simétricos em todas as direções entre componentes. Então há 6 módulos independentes e 15 módulos de interação. Então um material pode ter até 21 módulos independentes para descrever medições dependendo da simetria da estrutura do material. No caso de materiais isotrópicos, chapa de alumínio, cobre, fotorresistes SU-8 e AZ, vidro, as constantes elásticas se reduzem a duas apenas (eq. 3.7). Onde E é o módulo de Young, G é o módulo de torção, $\nu$ é o coeficiente de Poisson. 


$$
\begin{aligned}
& {[\boldsymbol{\sigma}]=\left\{\begin{array}{c}
\sigma_{x x} \\
\sigma_{y y} \\
\sigma_{z z} \\
\tau_{y z} \\
\tau_{x z} \\
\tau_{x y}
\end{array}\right\}=\left\{\begin{array}{c}
\sigma_{11} \\
\sigma_{22} \\
\sigma_{33} \\
\tau_{23} \\
\tau_{13} \\
\tau_{12}
\end{array}\right\}=\left\{\begin{array}{c}
\sigma_{1} \\
\sigma_{2} \\
\sigma_{3} \\
\tau_{4} \\
\tau_{5} \\
\tau_{6}
\end{array}\right\}} \\
& {[\boldsymbol{\epsilon}]=\left\{\begin{array}{c}
\epsilon_{x x} \\
\epsilon_{y y} \\
\epsilon_{z z} \\
\gamma_{y z} \\
\gamma_{x z} \\
\gamma_{x y}
\end{array}\right\}=\left\{\begin{array}{c}
\epsilon_{11} \\
\epsilon_{22} \\
\epsilon_{33} \\
\gamma_{23} \\
\gamma_{13} \\
\gamma_{12}
\end{array}\right\}=\left\{\begin{array}{c}
\epsilon_{1} \\
\epsilon_{2} \\
\epsilon_{3} \\
\gamma_{4} \\
\gamma_{5} \\
\gamma_{6}
\end{array}\right\}} \\
& \left\{\begin{array}{c}
\epsilon_{x x} \\
\epsilon_{y y} \\
\epsilon_{z z} \\
\gamma_{y z} \\
\gamma_{x z} \\
\gamma_{x y}
\end{array}\right\}=\left[\begin{array}{llllll}
c_{11} & c_{12} & c_{13} & c_{14} & c_{15} & c_{16} \\
c_{21} & c_{22} & c_{23} & c_{24} & c_{25} & c_{26} \\
c_{31} & c_{32} & c_{33} & c_{34} & c_{35} & c_{36} \\
c_{41} & c_{42} & c_{43} & c_{44} & c_{45} & c_{46} \\
c_{51} & c_{52} & c_{53} & c_{54} & c_{55} & c_{56} \\
c_{61} & c_{62} & c_{63} & c_{64} & c_{65} & c_{66}
\end{array}\right]\left\{\begin{array}{c}
\sigma_{x x} \\
\sigma_{y y} \\
\sigma_{z z} \\
\tau_{y z} \\
\tau_{x z} \\
\tau_{x y}
\end{array}\right\} \\
& \left\{\begin{array}{c}
\epsilon_{x x} \\
\epsilon_{y y} \\
\epsilon_{z z} \\
\gamma_{y z} \\
\gamma_{x z} \\
\gamma_{x y}
\end{array}\right\}=\left[\begin{array}{cccccc}
\frac{1}{E} & -\frac{\nu}{E} & -\frac{\nu}{E} & 0 & 0 & 0 \\
-\frac{\nu}{E} & \frac{1}{E} & -\frac{\nu}{E} & 0 & 0 & 0 \\
-\frac{\nu}{E} & -\frac{\nu}{E} & \frac{1}{E} & 0 & 0 & 0 \\
0 & 0 & 0 & \frac{1}{G} & 0 & 0 \\
0 & 0 & 0 & 0 & \frac{1}{G} & 0 \\
0 & 0 & 0 & 0 & 0 & \frac{1}{G}
\end{array}\right]\left\{\begin{array}{c}
\sigma_{x x} \\
\sigma_{y y} \\
\sigma_{z z} \\
\tau_{y z} \\
\tau_{x z} \\
\tau_{x y}
\end{array}\right\}
\end{aligned}
$$

onde $E=2 G(1+\nu)$

\subsubsection{Impedância Acústica}

A impedância acústica é o fator de proporcionalidade da relação entre a tensão mecânica $\sigma$ e a velocidade de partícula $v, \sigma=z v$. A impedância acústica para fluidos é dada pela equação:

$$
z=\rho c
$$


onde $\rho$ é a densidade, $c$ é a velocidade do som (LEMPRIERE, 2002).

\subsubsection{Onda Mecânica de Corpo ou Volume}

É considerada onda de corpo aquela que se propaga inteiramente dentro de um objeto e independe de seus contornos e formato. São ondas planas ou esféricas. A onda plana tem a mesma velocidade em todas as direções em um material isotrópico. Assim, ondas esféricas emitidas por uma fonte puntiforme, podem ser consideradas como um conjunto de ondas planas emitidas ao mesmo tempo. Analogamente, uma onda plana pode ser representada como um conjunto de ondas esféricas emitidas de pontos localizados num plano. Há dois tipos de onda de corpo, a longitudinal, que é paralela à direção de propagação e a transversal, que é perpendicular à direção de propagação. A onda transversal só pode existir em meio sólido. Em meios fluídos apenas a onda longitudinal pode se propagar.

\subsubsection{Interação da Onda com um Meio Elástico}

A velocidade de uma onda que se propaga no interior de um meio elástico uniforme é constante, dependendo somente da elasticidade e da densidade, que são constantes para a faixa utilizada em ultrassom. Todo material apresenta alguma não linearidade na relação força-deformação. Em um gás, por exemplo, a compressibilidade cai a medida que a pressão aumenta. Em líquidos e sólidos isso também ocorre, mas a compressibilidade é muito menor. Assim uma onda que se propaga em um meio sofre influência, tendo velocidade maior para maiores pressões. Uma onda que se propaga em um meio pode sofrer mudanças em sua amplitude (atenuação ou ganho) e/ou forma (distorção). Isso ocorre devido à propriedades do material, pois a maioria dos materiais não é puramente elástica, podendo por exemplo, absorver energia da onda (atenuação).

Uma onda se propagando num meio lhe transmite mudança de estado (tensão e velocidade de partícula). Ao encontrar outra onda, as duas se interagem com adição algébrica nas mudanças na tensão e na velocidade. A interferência entre as ondas de diferentes formas é construtiva nas regiões em que as duas se encontram em fase, resultando em picos de alta amplitude. Nas regiões em que os picos das ondas não se coincidem, a interferência é 
destrutiva resultando em picos de baixa amplitude.

Quando uma onda encontra uma superfície plana livre, transmite ao meio um estado tensão-velocidade. Quando a onda atinge a fronteira livre é induzida uma onda refletida que tende levar a tensão para zero. Isto induz a uma mudança de velocidade. Pode-se imaginar a onda refletida como uma onda virtual que se inicia em um ponto fora da superfície, mas que se propaga como se estivesse dentro do material. Quando uma onda plana incide normalmente numa interface entre dois materiais, há indução de uma onda refletida e de uma que atravessa para o material dois. A proporção entre a onda refletida e a transmitida depende das impedâncias dos dois materiais. Caso estas sejam iguais não há reflexão. Mais detalhes em (LEMPRIERE, 2002).

Em casos em que a onda precisa passar de um material para outro com propriedades muito diferentes, pode-se utilizar um material com impedância intermediária entre os dois meios. Isso reduz a perda de amplitude da onda transmitida. A espessura da camada intermediária está relacionada ao comprimento de onda da onda incidente. Esta configuração é chamada de filtro de quarto de onda, pois bloqueia ondas com um quarto do comprimento de onda em relação à onda incidente. Assim minimiza-se interferências destrutivas.

\subsubsection{Utilização de Ondas em Meios Líquidos}

A utilização de ondas em aplicações subaquáticas apresenta uma vasta faixa de frequências. Comunicações acústicas a centenas de quilômetros nos oceanos são possíveis com frequências abaixo de $100 \mathrm{~Hz}$. Sonares de alta resolução, usam frequências até $5 \mathrm{MHz}$. Aplicações navais subaquáticas de som requerem um vasto número e variedade de transdutores. A comunicação entre submarinos requer um projetor para transmitir o som e um hidrofone para receber. Entretanto, projetores e hidrofones frequentemente são usados em grandes grupos de mil ou mais transdutores encasulados em arrays planares, cilíndricos ou esféricos montados em chips navais. Entre os vários tipos de mecanismos de transdução eletroacústica, destacam-se o piezoelétrico e o eletrostático. O eletrostático, de maior interesse para este trabalho é do tipo transdutor de força de superfície (surface force transducers) pois a força se origina em superfícies. 
A função de um transdutor eletroacústico é irradiar um som em um meio como ar ou água ou detectar um som nesse meio. Em transdutores eletrostáticos, a força gerada eletricamente age na superfície das placas do capacitor. Transdutores eletrostáticos são muito importantes em MEMS mas têm sido pouco usados em aplicações sonoras subaquáticas (SHERMAN, 2007).

O CMUT proposto neste trabalho pertence a essa classe de transdutor, e utiliza a técnica do pulso-eco para analisar líquidos. As distâncias que os sinais devem viajar são muito pequenas comparadas à aplicações náuticas.

\subsection{Piezoeletricidade}

Uma vez que o dispositivo proposto neste trabalho é geralmente utilizado como alternativa ou complemento aos dispositivos piezoelétricos faz-se conveniente uma breve explanação sobre piezoeletricidade e dispositivos piezoelétricos.

No inicio dos anos 1880 os irmãos Paul-Jaques e Pierre Curie descobriram que ao se aplicar uma força externa a certos cristais era possível gerar uma certa diferença de potencial na superfície do cristal (MADOU, 2002). Um ano depois descobriram o efeito inverso, ou seja, a aplicação de uma voltagem causa uma deformação no cristal.

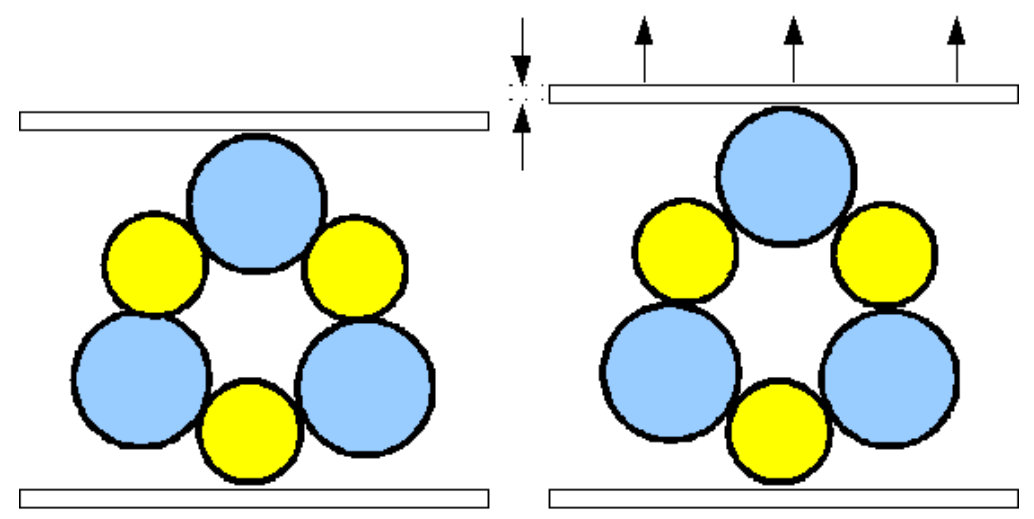

Figura 3.2: Material piezoelétrico

Basicamente o efeito da piezoeletricidade se deve ao movimento de cátions e ânions em direções opostas no cristal em decorrência de um campo elétrico ou de uma força mecânica. A figura 3.2 mostra esse efeito no quartzo. Se a célula é deformada por forças de tensão ou compressão o 
ânion de oxigênio se move, o que gera cargas negativas ou positivas. Assim todo material piezoelétrico é necessariamente anisotrópico. Caso houvesse simetria no centro, a aplicação de força não poderia gerar polarização. Como visto no exemplo do quartzo, em um cristal piezoelétrico, o movimento de íons gera um dipolo elétrico no cristal causando diferença de potencial. 


\section{Microtransdutores}

Os microtransdutores (transdutores em escala micrométrica) são MEMS que podem ser sensores ou atuadores. Esses dispositivos possuem um circuito elétrico de controle e componentes mecânicos que executam trabalho para uma determinada aplicação. Esses dispositivos são utilizados em diversos campos e permitiram a criação e miniaturização de diversos aparelhos.

Atualmente a maioria dos micro-transdutores utilizados no mercado é do tipo piezoelétrico. Esses dispositivos utilizam-se de cerâmicas piezoelétricas. Ao receber um estímulo elétrico, essas cerâmicas vibram. Essa vibração controlada é a responsável pelo movimento desses micro-transdutores. Em menor número existem também pesquisas referentes a transdutores eletrostáticos. Neste caso o movimento se dá por atração e/ou repulsão eletrostática entre dois eletrodos.

\subsection{CMUTs e Alguns Métodos de Fabricação}

O transdutor ultra-sônico capacitivo ou CMUT (do inglês - Capacitive Micromachined Ultrasonic Transducer) é um tipo de transdutor ultra-sônico que vem sendo estudado por alguns grupos de pesquisadores.

Há diferentes processos de fabricação sendo utilizados. A maioria desses processos utiliza fabricação em superfície com algumas diferenças em relação à ordem de algumas etapas e às técnicas utilizadas. Também é possível utilizar processos de fabricação em substrato. Alguns pesquisadores como Ergun et al. (2005) utilizam um processo chamado wafer bonding, no qual são utilizadas duas lâminas de silício (fig. 4.1). Abaixo será descrito um exemplo de processo de fabricação em superfície. Um exemplo de processo de fabricação em superfície pode ser visto em Ergun, Yaralioglu e Khuri-Yakub (2003). O processo inicia-se com uma lâmina de Si de baixa condutividade. A lâmina é então, altamente dopada para adquirir 


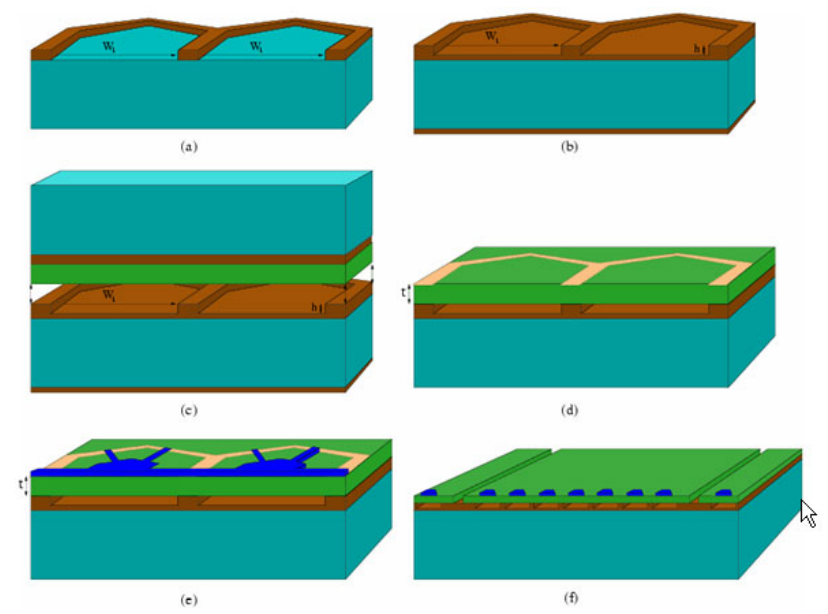

Figura 4.1: Processo de fabricação de CMUT por wafer bonding utilizado por Ergun et al. (2005)

alta condutividade na superfície que será o eletrodo inferior do CMUT. Uma alternativa à dopagem é a utilização de um filme fino condutor, o que reduz a capacitância parasitária (KNIGHT; MCLEAN; DEGERTEKIN, 2004). Então uma fina camada de $\mathrm{Si}_{3} \mathrm{~N}_{4}$ é depositada sobre o substrato. Essa camada serve como etch stop durante a remoção da camada sacrificial. Uma camada de Si policristalino é depositada e definida por litografia, trata-se da camada sacrificial. Esta camada também pode ser de Si amorfo ou de metal. A deposição pode ser feita por LPCVD em processos que utilizam a técnica para ter filmes de melhor qualidade. Para processos que exigem baixa temperatura, a deposição pode ser feita por PECVD. No caso desta camada ser composta por um metal, a deposição pode ser feita por sputtering. Então é depositada uma segunda camada de $S_{3} N_{4}$ por LPCVD ou PECVD. Esta camada fará parte da placa. São abertos na camada de $S i_{3} N_{4}$, orifícios chamados de etch holes através de corrosão seca (necessário litografia). Esses orifícios ficam em volta da placa e servem para que a solução que removerá a camada sacrificial possa entrar na cavidade. Então é utilizada uma solução líquida para fazer a corrosão da camada sacrificial. Nesta etapa, o reagente usado para corrosão deve apresentar grande seletividade entre a camada sacrificial e o $S i_{3} N_{4}$. Uma camada de Si policristalino, por exemplo, pode ser removida com $\mathrm{KOH}$. O reagente deve corroer a camada sacrificial o mais rápido possível sem corroer significativamente a placa de $\mathrm{Si}_{3} N_{4}$. KOH resfriado fornece a seletividade necessária entre o Si poli e o $\mathrm{Si}_{3} \mathrm{~N}_{4}$ ( 400000:1) (ERGUN; YARALIOGLU; KHURI-YAKUB, 2003). O tamanho e a espessura da placa e do gap têm grande importância nesse processo. Forças 
capilares que agem na placa durante a secagem podem faze-la colapsar para o substrato permanentemente. O tamanho e a espessura devem ser projetados e processados apropriadamente. Após a liberação da placa, o gap é selado com uma terceira camada de $S i_{3} N_{4}$. Esta camada cobre todas as superfícies fechando os etch holes. Também pode ser depositada por LPCVD ou PECVD dependendo do processo adotado. Após essas etapas a placa pode ser corroída para reduzir sua espessura ao valor final desejado. Então é feita uma abertura através do $S i_{3} N_{4}$ para se ter acesso ao eletrodo inferior do CMUT. Essa abertura pode ser feita através de RIE. Então é depositado alumínio (por sputtering) e feita litografia para definição do eletrodo superior e dos pads. A etapa final é cobrir os eletrodos com uma camada isolante (LTO) e definir essa camada (litografia) para o wire bonding.

No processo acima descrito, o eletrodo superior é depositado após a remoção da camada sacrificial. Há processos em que esse eletrodo é depositado antes como em Knight, McLean e Degertekin (2004), que realizam um processo a baixa temperatura e Caronti et al. (2006), que cobrem a lâmina com oxido de silício antes de iniciar o processo, usam eletrodos de alumínio e camada sacrificial de cromo. Pesquisadores do mesmo grupo (CALIANO et al., 2005) também propõem um "processo reverso". Neste processo, toda a estrutura é fabricada sobre o substrato de silício com eletrodos de Al e camada sacrificial de cromo. Mas no final, a estrutura é "colada" em um outro substrato, virada, e a lâmina de silício é totalmente corroída. Deste modo, as primeiras camadas depositadas é que farão parte da placa. Uma das vantagens é que os etch holes não estarão perfurando a placa e sim a parte de baixo do dispositivo, o que não agride a placa como outros processos.

Knight, McLean e Degertekin (2004) destacam alguns problemas com relação à escolha do metal dos eletrodos. O grupo investigou três metais para serem usados como eletrodo, o alumínio, o cromo e o ouro. O alumínio sofre oxidação durante o subsequente processo de deposição nitreto de silício. Com isso o alumínio não se mostrava uma boa opção para a aplicação em questão que usava baixas espessuras (da ordem de 1500 angstrons). O cromo não sofre essa oxidação mas por outro lado tem alta resistividade. Somente o ouro não apresentou nenhum desses problemas. Para o eletrodo superior, o grupo usou o artifício de depositar uma camada de alumínio seguida de uma fina camada de cromo. Assim foi possível fazer a cobertura final dos eletrodos com nitreto de silício. O alumínio fornece a condutividade que o 
eletrodo precisa e o cromo impede a oxidação do alumínio.

\subsection{Aplicações para CMUTs}

A grande maioria das pesquisas envolvendo CMUT está focada na área médica. O dispositivo pode ser fabricado com características tais que permitam emitir ou receber ondas ultrassônicas. Assim há um grande esforço em estudos relacionados à utilização do CMUT para imagens por ultrassom. O grupo de Khuri-Yakub da Universidade de Stanford, estuda largamente o CMUT para esse tipo de aplicação. Este e outros grupos destacam as características do CMUT apontando-o como complemento ou alternativa aos transdutores piezoelétricos (DEMIRCI et al., 2004; JIN; CHENG; ORALKAN, 1999).

Existem em menor volume pesquisas envolvendo CMUTs para outras aplicações. Lee et al. (2008) desenvolveram um sensor para detectar DMMP (dimethyl methylphosphonate) uma espécie de simulador para o agente nervoso sarin. Estes pesquisadores utilizam uma camada a mais na fabricação de seu CMUT. Sobre as placas móveis é depositado um filme que favorece a adesão da substância que se quer detectar. Assim, moléculas do gás se aderem sobre as placas. A mudança da massa sobre a placa muda a frequência de ressonância do dispositivo. Dessa maneira, o CMUT trabalha basicamente como um sensor de massa.

THRÄNHARDT et al. (2009), THRÄNHARDT e Eccardt (2009) propõem o uso de dispositivos tipo CMUT como sensor para fluído sem o uso de uma camada sensível. Estes pesquisadores utilizam o CMUT como sensor de ondas de superfície. São utilizadas placas retangulares que utilizam tensões em fases diferentes. É utilizado o modelo de equivalência entre circuitos eletro-mecânico. O componente equivalente elétrico Ls tem dependência linear com a densidade do fluído. Ao analisar o espectro de impedância do CMUT em diferentes meios (ar, água, óleo de silicone e óleo vegetal), os pesquisadores verificaram que haviam diferenças nas frequências de ressonância. Assim concluíram que o CMUT pode operar como sensor de ondas de superfície. 


\section{Modelagens e Simulações}

É importante ter em mente a mecânica por trás do funcionamento do CMUT. Todo movimento produzido está basicamente concentrado em seu eletrodo superior, que alguns autores chamam de "membrana". Em teoria de Estruturas (Mecânica dos Sólidos), o termo "membrana" se refere a um tipo de estrutura plana com dimensões de comprimento e largura não nulas, enquanto que a espessura é considerada desprezível (nula). Por outro lado, o termo "placa" se refere a um tipo de estrutura tridimensional com dimensões de comprimento, largura e espessura. As placas podem ser finas, médias ou grossas relativamente à espessura (TIMOSHENKO; WOINOWSKY-KRIEGER, 1959). Nas modelagens deste trabalho os eletrodos superiores móveis são considerados como placas. Foi considerado que o plano $x$-y contém as dimensões de comprimento e largura. As deflexões ocorrem na direção $z$ (direção vertical das figuras 5.1 e 5.2).

Quando o CMUT é submetido a uma carga que deflete sua placa em direção ao eletrodo inferior, como uma tensão $\mathrm{CC}$, a placa oferece resistência ao movimento agindo como uma mola. O modelo da figura 5.2 ilustra esse efeito. Na situação I a placa está em repouso livre de tensão mecânica. $\mathrm{Na}$ situação II foi aplicada uma tensão $\mathrm{CC}$, que induziu cargas na placa e no eletrodo inferior. Com isso, a placa se deflete aproximando-se do eletrodo

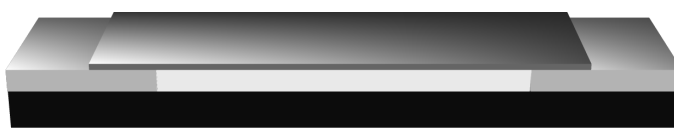

CMUT

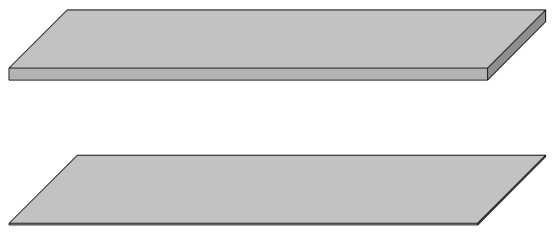

Placa

Figura 5.1: CMUT com eletrodo superior em forma de placa. 


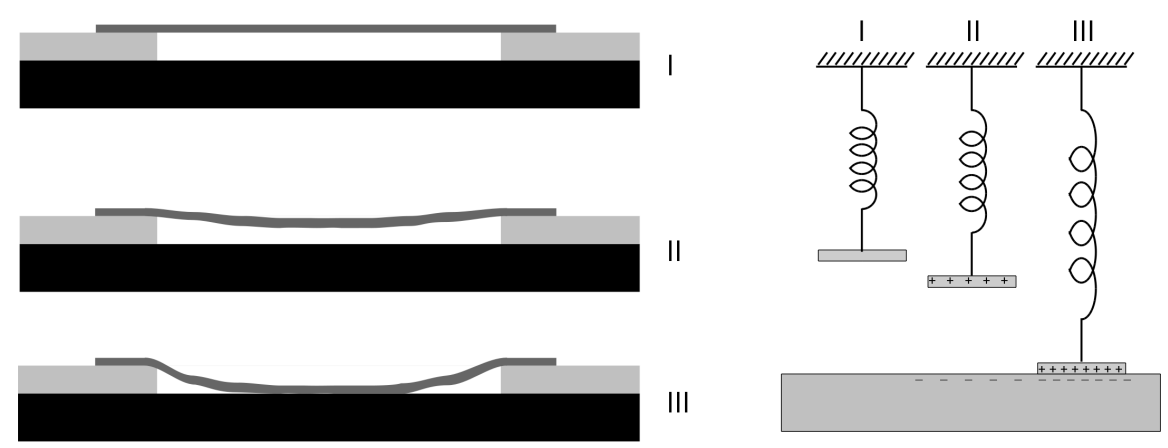

Figura 5.2: Modelo representando a força de mola da placa.

inferior. Como a placa está tensionada, há uma força de mola que tende a fazê-la voltar à sua posição de repouso. Na situação III, a tensão CC venceu a força de mola e a placa entrou em colapso. Geralmente essa situação deve ser evitada pois a placa tem sua liberdade de movimento reduzida ao ser excitada por uma onda ultrassônica ou tensão CA. Além disso, se não houver uma camada de dielétrico entre o eletrodo inferior e a placa, haverá curto-circuito.

\subsection{Acoplamento Eletro-Mecânico}

Um transdutor eletro-mecânico pode converter energia elétrica em energia mecânica e vice-versa. Um CMUT é constituído de um sistema elétrico e de um sistema mecânico que interagem por acoplamento. Assim, a análise de um CMUT é análoga a de um sistema eletromecânico, que pode ser representado (HUNT, 1954) de forma genérica conforme a figura 5.3.

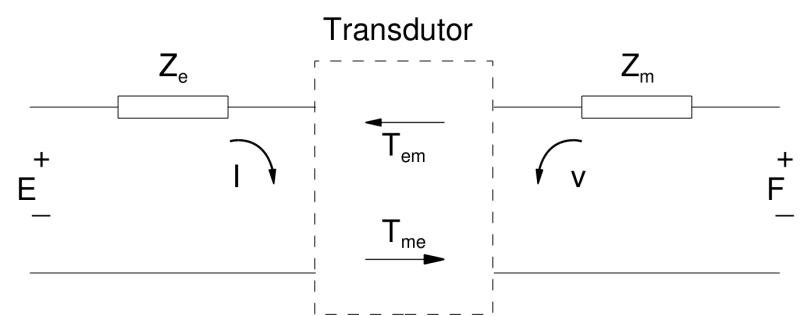

Figura 5.3: Representação de acoplamento eletro-mecânico genérico. Adaptado de Hunt (1954).

A malha elétrica, representada pela impedância elétrica $Z_{e}$, fonte de tensão elétrica $E$ e corrente $I$, é acoplada pelo elemento transdutor à malha mecânica, representada por uma impedância mecânica $Z_{m}$, força $F$ e velocidade $v$. Os coeficientes de transdução são representados por $T_{e m}$ (força eletromotriz de transdução para o sistema elétrico devido ao sistema 
mecânico); e $T_{m e}$ (força por unidade de corrente no sistema mecânico devido ao sistema elétrico).

Um primeiro modelo mais simplificado despreza as ações de diversos efeitos como forças gravitacionais, forças devido à ação da pressão atmosférica, resistência devido à compressão de ar existente no interior da cavidade do CMUT e efeitos dissipativos (resistências mecânicas e elétricas). Assim, o acoplamento dos sistemas eletro-mecânico pode ser representado por um sistema de duas equações:

$$
\begin{gathered}
E=Z_{e} I+T_{e m} v \\
F=T_{m e} I+Z_{m} v
\end{gathered}
$$

\subsubsection{Modelo Simplificado}

Numa primeira análise, um CMUT pode ser considerado como um sistema composto por uma massa móvel (placa do eletrodo superior móvel), uma mola de primeira ordem (flexão da placa do eletrodo superior), e um capacitor de placas planas infinitas. O modelo é justificado pois, normalmente, o raio do eletrodo superior é muito maior que a altura da cavidade, e os esforços envolvidos resultam em tensões mecânicas no material da placa ainda no regime elástico.

Considere um CMUT genericamente atuado pela combinação de um sinal de corrente contínua (CC) e de um sinal de corrente alternada (CA) senoidal. O sinal CC gera cargas elétricas nos eletrodos (polarização) e permite a aproximação entre os eletrodos, aumentando a capacitância. Paralelamente, a movimentação do eletrodo superior devido ao sinal CC gera uma deflexão na placa equivalente a uma solicitação num sistema mecânico massa-mola. O sinal CA promove a oscilação da placa para gerar a onda no meio de propagação. A equação de força resultante na placa será:

$$
F_{\text {massa }}=F_{\text {mola }}+F_{\text {capacitor }}
$$

A força de mola média na placa do eletrodo superior, supondo o sistema no regime elástico, pode ser considerada do tipo $F_{\text {mola }}=-k u(t)$, onde $k$ é uma constante de mola equivalente, e $u(t)$ é o deslocamento em função do 
tempo.

A força do capacitor no eletrodo móvel pode ser encontrada diferenciando a energia (trabalho) no capacitor em função do deslocamento. Supondo uma capacitância $C=\epsilon S /\left(g_{0}-u(t)\right)$ na placa de área $S$, com dielétrico de permissividade $\epsilon$, e altura de cavidade $g_{0}$ no estado inicial (sem esforços) ao ser aplicada uma tensão total $V=V_{C C}+V_{C A}=V_{C C}+A \cos (\omega t)$ para um sinal alternado cossenoidal de amplitude $A$ e frequência $\omega$ :

$$
F_{\text {capacitor }}=\frac{d}{d u(t)}\left(\frac{1}{2} C V^{2}\right)=\frac{1}{2} \frac{d}{d u(t)}\left[\left(\frac{\epsilon S}{g_{0}-u(t)}\right) V^{2}\right]=\frac{\epsilon S V^{2}}{2\left(g_{0}-u(t)\right)^{2}}
$$

Assim, a equação resultante de forças pode ser escrita como:

$$
m \frac{d^{2} u(t)}{d t^{2}}=-k u(t)+\frac{\epsilon S V^{2}}{2\left(g_{0}-u(t)\right)^{2}}
$$

Um caso importante a considerar é a ação apenas da tensão contínua, com $V_{C A}=0$ e $V=V_{C C}$. Neste caso, a movimentação da placa superior móvel do CMUT não é função do tempo. Assim, a equação 5.4 de força se reduz a:

$$
0=-k u(t)+\frac{\epsilon S V_{C C}^{2}}{2\left(g_{0}-u(t)\right)^{2}}
$$

Reagrupando os termos:

$$
2 k u^{3}-4 k g_{0} u^{2}+2 k g_{0}^{2} u-\epsilon S V_{C C}^{2}=0
$$

Essa equação de terceiro grau apresenta três raízes. Para valores suficientemente baixos de $V_{C C}$, a força da mola consegue se opor à força eletrostática do capacitor e o sistema entra em equilíbrio estático; neste caso, apenas uma das três raízes é viável fisicamente. Entretanto, haverá um valor limite para $V_{C C}$ a partir do qual a força eletrostática no capacitor é maior que a força de oposição da mola; neste caso, o eletrodo superior móvel se desloca até colapsar e encostar no eletrodo inferior. Essa situação de colapso ocorre para $u=g_{0} / 3$, e o valor da tensão de colapso será:

$$
V_{C C}=V_{\text {colapso }}=\sqrt{\frac{8 k g_{0}^{3}}{27 \epsilon S}}
$$


Uma outra consideração importante pode ser feita relativa ao efeito da força eletrostática do capacitor sobre a força da mola. Na equação completa de forças 5.4, é possível linearizar o termo da força do capacitor usando série de Taylor em torno da posição $u(t)=0$. Consideranto $g_{0} \gg u(t)$, resulta:

$$
m \frac{d^{2} u(t)}{d t^{2}}+k u(t)-\left[\frac{\epsilon S V^{2}}{2 g_{0}^{2}}+\frac{\epsilon S V^{2}}{g_{0}^{3}} u(t)\right]=0
$$

Reagrupando os termos, pode ser notada uma modificação na constante de mola efetiva:

$$
\begin{gathered}
m \frac{d^{2} u(t)}{d t^{2}}+\left[k-\frac{\epsilon S V^{2}}{g_{0}^{3}}\right] u(t)-\frac{\epsilon S V^{2}}{2 g_{0}^{2}}=0 \\
k_{\text {efetivo }}=k-\frac{\epsilon S V^{2}}{g_{0}^{3}}
\end{gathered}
$$

Note que o $k_{\text {efetivo }}$ representa um amolecimento de mola. Esse efeito também deverá resultar numa diminuição na frequência natural de vibração com o aumento da tensão elétrica aplicada $V$.

\subsection{Materiais para CMUT}

Foram realizadas modelagens analítica e computacional para prever o comportamento da placa submetida à uma carga e os efeitos eletro-mecânicos quando há aplicação de uma diferença de potencial. Nestas modelagens é importante considerar a adequação do material a esta aplicação. A tabela 5.1 apresenta propriedades de materiais importantes empregados na fabricação e/ou modelagens. O SU-8 que aparece na tabela é da série 2000 , que foi utilizado na fabricação.

Tabela 5.1: Propriedade de alguns materiais utilizados nas modelagens

\begin{tabular}{|lllll|}
\hline Material & $\begin{array}{l}\text { Módulo de } \\
\text { Young }\end{array}$ & Poisson & $\begin{array}{l}\text { Densidade } \\
\left(\mathrm{kg} / \mathrm{m}^{3}\right)\end{array}$ & $\begin{array}{l}\text { Constante } \\
\text { dielétrica }\end{array}$ \\
\hline SU-8 & $2,0 \mathrm{GPa}$ & 0,22 & 1190 & 3,2 \\
Silício & $127 \mathrm{GPa}$ & 0,278 & 2330 & 11 \\
Cobre & $119 \mathrm{GPa}$ & 0,326 & 8960 & - \\
Alumínio & $71 \mathrm{GPa}$ & 0,334 & 2700 & - \\
\hline
\end{tabular}




\subsection{Modelagem Analítica}

A modelagem e as simulações analíticas foram baseadas em (YOUNG; BUDYNAS, 2002) e utilizam dois de seus modelos de placas planas, um para placa circular e outro para placa retangular (fig. 5.4). O modelo de placa retangular foi utilizado para modelar CMUTs de placas quadradas. Ambos modelos consideram a placa plana engastada em todas a bordas. Para uma placa circular temos:

$$
\begin{array}{r}
y_{a}=0, \theta a=0 \\
y_{c}=\frac{-q a^{4}}{2 D}\left(L_{14}-2 L_{11}\right) \\
M_{c}=q a^{2}(1+v) L_{14} \\
M_{r a}=\frac{-q}{8 a^{2}}\left(a^{2}-r_{0}^{2}\right) \\
\sigma_{\max }=6 M_{c} t^{2}
\end{array}
$$

Onde $y_{c}$ é a deformação no centro da placa pela ação de uma carga (pressão atmosférica, por exemplo), $\sigma_{\max }$ é a tensão máxima que ocorre nas bordas da placa. Se há aplicação de pressão por toda a placa, temos:

$$
\begin{array}{r}
y_{c}=\frac{-q a^{4}}{64 D} \\
M_{c}=\frac{q a^{2}(1+v)}{16} \\
M_{r a}=\frac{-q a^{2}}{8}
\end{array}
$$

$M_{c}$ tem unidade de pressão e é utilizado para calcular a tensão máxima (eq.5.14).

Para uma placa quadrada engastada temos a tensão $\sigma$ dada pela eq 5.18 


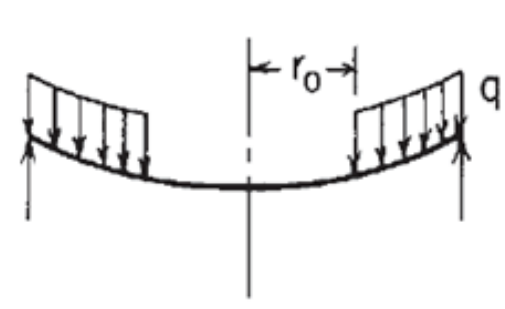

a

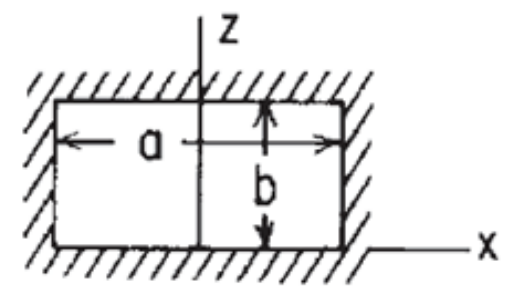

b

Figura 5.4: Modelos utilizados na modelagem analítica (a) para placa circular, (b) para placa retangular (YOUNG; BUDYNAS, 2002).

e o deslocamento máximo $y_{\max }$ dado pela eq 5.19.

$$
\begin{array}{r}
\sigma=\frac{\beta_{2} q b^{2}}{t^{2}} \\
y_{\max }=\frac{\alpha a b^{4}}{E t^{3}}
\end{array}
$$

E é o Módulo de Young, q a pressão atmosférica, b a largura da placa e $\mathrm{t}$ a espessura da placa. Os valores de $\alpha$ e $\beta$ podem ser extraídos da tabela 5.2. Como a placa é quadrada, são extraídos valores para $a / b=1$. Foram utilizadas propriedades mostradas na tabela 5.1.

Tabela 5.2: Valores das constantes $\beta_{1}, \beta_{2}$ e $\alpha$

\begin{tabular}{|lccccccc|}
\hline$a / b$ & 1.0 & 1.2 & 1.4 & 1.6 & 1.8 & 2.0 & $\infty$ \\
\hline$\beta_{1}$ & 0,3078 & 0,3834 & 0,4356 & 0,4680 & 0,4872 & 0,4974 & 0,5000 \\
$\beta_{2}$ & 0,1368 & 0,1794 & 0,2094 & 0,2286 & 0,2406 & 0,2472 & 0,2500 \\
$\alpha$ & 0,0138 & 0,0188 & 0,0226 & 0,0251 & 0,0267 & 0,0277 & 0,0284 \\
\hline
\end{tabular}

\subsection{Modelagem Computacional}

Foram desenvolvidos modelos para realizar simulações utilizando o Ansys, um software de elementos finitos. Os modelos também apresentam placa engastada nas bordas como o modelo de (YOUNG; BUDYNAS, 2002).

Essas simulações têm por objetivo prever o comportamento do dispositivo e determinar diversos parâmetros. Entre esses parâmetros se encontram a espessura da placa, a dimensão da cavidade, o formato da placa, o diâmetro da placa (em caso de placa circular) ou o comprimento e a largura (em caso de placa retangular). Foram realizadas simulações estáticas para prever o 


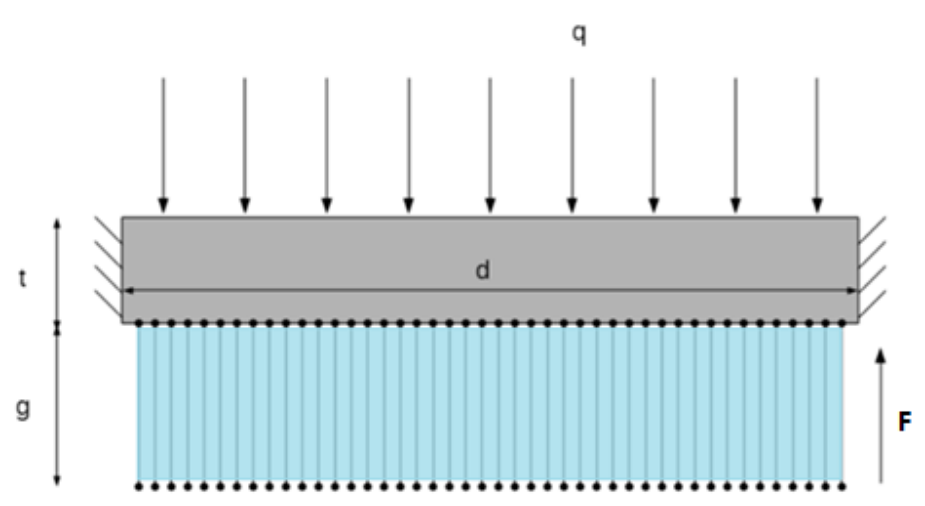

Figura 5.5: Exemplo de modelo utilizado na simulação do comportamento da placa submetida a uma tensão CC

comportamento do dispositivo sob ação de uma tensão de polarização CC para diferentes materiais. A figura 5.5 mostra o modelo utilizado, composto uma placa circular de diâmetro $\mathbf{d}$ e espessura $\mathbf{t}$, $\mathbf{g}$ é o gap (cavidade) entre o eletrodo inferior e a placa flexível. O material utilizado é o alumínio, sendo utilizado seu módulo de Young 71GPa e coeficiente de Poisson 0,334. Para a placa foi utilizado um elemento tetraedro chamado SOLID 92. Para o efeito capacitivo da estrutura foi utilizado um elemento eletro-mecânico chamado TRANS 126, que basicamente converte energia eletrostática em energia mecânica e vice-versa. F é a força de resistência do ar que se opõe à $\mathbf{q}$, a pressão atmosférica. Essa força é utilizada pois o modelo simula CMUTs cujas cavidades não estão em vácuo.

\subsection{Resultados de Simulações Analíticas}

A tabela 5.3 mostra os resultados das simulações analíticas para placas de cobre submetidas a uma carga equivalente à pressão atmosférica. Os resultados para placas de alumínio estão na tabela 5.4

Os resultados mostram deformações significativas para os maiores diâmetros. As dimensões foram escolhidas com base nos processos de fabricação planejados. As placas de alumínio se deformam mais que as de cobre considerando uma mesma espessura. Além disso, o processo de fabricação permite fabricar placas de alumínio mais finas em relação às de cobre. 
Tabela 5.3: Resultados das simulações analíticas com placas de cobre

\begin{tabular}{|c|c|c|}
\hline $\begin{array}{l}\text { Espessura } \\
\text { da placa } \\
(\mu \mathrm{m})\end{array}$ & $\begin{array}{l}\text { Diâmetro da } \\
\text { placa }(\mu \mathrm{m})\end{array}$ & $\begin{array}{l}\text { Deslocamento } \\
(\mu \mathrm{m})\end{array}$ \\
\hline 10 & 500 & 0,557 \\
\hline 10 & 600 & 1,156 \\
\hline 10 & 800 & 3,653 \\
\hline 10 & 1000 & 8,918 \\
\hline 30 & 500 & 0,021 \\
\hline 30 & 600 & 0,043 \\
\hline 30 & 800 & 0,135 \\
\hline 30 & 1000 & 0,330 \\
\hline
\end{tabular}

Tabela 5.4: Resultados das simulações analíticas com placas de alumínio

\begin{tabular}{|c|c|c|}
\hline $\begin{array}{l}\text { Espessura } \\
\text { da placa } \\
(\mu \mathrm{m})\end{array}$ & $\begin{array}{l}\text { diâmetro da } \\
\text { placa }(\mu \mathrm{m})\end{array}$ & $\begin{array}{l}\text { deslocamento } \\
(\mu \mathrm{m})\end{array}$ \\
\hline 10 & 500 & 0,929 \\
\hline 10 & 600 & 1,926 \\
\hline 10 & 800 & 6,086 \\
\hline 10 & 1000 & 14,858 \\
\hline 30 & 500 & 0,034 \\
\hline 30 & 600 & 0,071 \\
\hline 30 & 800 & 0,225 \\
\hline 30 & 1000 & 0,550 \\
\hline
\end{tabular}

\subsection{Resultados de Simulações Computacionais}

Para as simulações no software de elementos finitos foram utilizados os valores da tabela 5.5. O gráfico da figura 5.6 mostra como a placa de alumínio se deforma devido a diferentes tensões CC aplicadas.

Tabela 5.5: Parâmetros utilizados nas simulações computacionais

\begin{tabular}{|cc|}
\hline Parâmetro & Valor \\
\hline $\mathrm{t}$ (espessura da placa) & $10 \mu \mathrm{m}$ \\
$\mathrm{d}$ (diâmetro da placa) & $800 \mu \mathrm{m}$ \\
$\mathrm{q}$ (pressão atmosférica) & $1 \mathrm{Atm}$ \\
$\mathrm{g}$ (profundidade da cavidade) & $0,5 \mu \mathrm{m}$ \\
\hline
\end{tabular}

Para as dimensões utilizadas, tensões a partir de 30V produzem grandes deformações na placa. Essa deformação é importante para aumentar a força elástica da placa bem como aproximá-la do eletrodo inferior. Assim, 


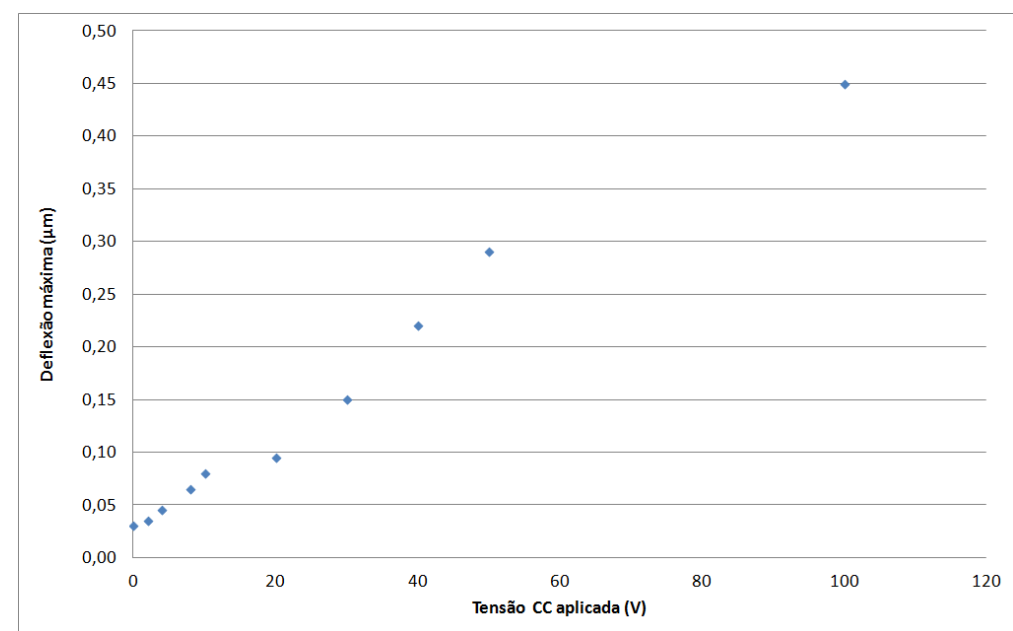

Figura 5.6: Deflexões obtidos para diferentes tensões de polarização aplicadas

aplicando-se a polarização adequada, a placa poderá vibrar acompanhando um sinal elétrico ou uma onda acústica a uma determinada frequência. Essa frequência está relacionada à inércia da placa. Ou seja, dependera da sua massa estando relacionada à espessura e ao tipo de material. Utilizando-se dimensões e tensão de polarização adequados, o CMUT pode trabalhar como sensor ou emissor de ondas acústicas numa frequência de interesse. 


\section{Fabricação}

Foram planejados vários processos de fabricação para obtenção de protótipos do CMUT. Os processos deveriam ser relativamente simples levando em conta os equipamentos e materiais disponíveis nos laboratórios LSI e LNLS. A fabricação envolve o planejamento das etapas, a escolha dos materiais, o desenvolvimento das máscaras, testes de processos planejados e finalmente a fabricação propriamente dita.

Inicialmente, planejou-se a utilização de processos envolvendo camada sacrificial e processos utilizando colagem. No processo de camada sacrificial, o dispositivo deve ser fabricado em substrato único com a deposição das camadas sucessivamente. A cavidade é preenchida por um material de sacrifício e sobre essa camada são depositados a placa e o eletrodo superior. Então na(s) última(s) camada(s) deve ser aberto acesso para que se remova a camada sacrificial via corrosão úmida isotrópica. A placa e o eletrodo superior podem ser resumidos a uma camada única utilizando-se um material condutor.

No processo de colagem, o dispositivo deve ser fabricado em dois substratos. Em um dos substratos fabrica-se os eletrodos inferiores e as cavidades. Essa parte do dispositivo será chamada de base. Em outro substrato é depositada a placa. Então as duas partes devem ser coladas colocando-se a placa em contato com as cavidades e realizando um processo que promova a colagem. Após a colagem o substrato que carregava a placa do dispositivo deve ser removido. Detalhes desse processo, que permitiu a fabricação de diversos protótipos, são descritos na seção 6.2.

O fotorresiste negativo SU-8 foi escolhido como material de parte do CMUT. A estrutura formada por esse material sustenta as placas e os eletrodos superiores; pode ser chamada de postes (ou pilares). Para os eletrodos do dispositivo foram escolhidos o alumínio e o cobre. O alumínio do eletrodo inferior é depositado por evaporação térmica, um processo relativamente simples de deposição física. O cobre foi utilizado na forma de 
folha em um dos processos de fabricação por colagem. Antes de ser colada, a folha de cobre tem sua espessura reduzida por corrosão úmida utilizando-se ácido clorídrico ou ácido nítrico.

Foram utilizadas máscaras de fotolito para a fabricação dos protótipos. A utilização de fotolito é uma solução relativamente barata e satisfaz as exigências do processo uma vez que o dispositivo apresenta dimensões relativamente grandes. As máscaras foram desenhadas utilizando-se o kicad, software para circuito impresso, e então são enviadas para impressão em fotolito.

\subsection{Testes}

Antes de iniciar o processo de fabricação foram realizados diversos testes. $O$ objetivo destes testes era verificar a viabilidade dos processos e adaptações planejados para a fabricação dos protótipos.

Parte dos testes se concentraram em tentar encontrar um bom material de sacrifício que também seria útil para o processo de fabricação por colagem. Neste caso, esse material seria depositado sobre o substrato secundário e sobre ele seria depositada a placa. Após a colagem esse material seria removido. $O$ fotorresiste $A Z$ foi o primeiro a ser testado devido à facilidade de aplicação; disponibilidade em ambos laboratórios utilizados; e também devido ao fato de ser um fotorresiste positivo ao passo que o SU-8 é negativo. Desta maneira uma exposição feita de maneira conveniente pode ao mesmo tempo tornar o AZ solúvel e o SU-8 insolúvel nas regiões em que há exposição à luz ultravioleta.

Deposita-se o AZ sobre um substrato de vidro ou de acetato. Sobre o AZ deposita-se uma camada de SU-8 que seria a placa do CMUT. Após a colagem de SU-8 com SU-8, o conjunto é colocado no revelador de AZ. Esperava-se que o revelador dissolvesse o fotorresiste AZ. Assim a placa seria liberada do substrato secundário permanecendo colada à base do dispositivo. Entretanto, esse processo não apresentou resultados satisfatórios o bastante para que se fabricassem bons protótipos. Havia alguma dificuldade na colagem de SU-8 com SU-8. Além disso, o revelador do AZ não estava removendo esse fotorresiste para liberar a placa.

Os resultados deste teste e de testes posteriores indicam que ocorre 
interação entre os dois fotorresistes durante a litografia. Esta interação dificulta a remoção do fotorresiste AZ. Entretanto esse fenômeno será útil em outro processo como será descrito na seção 6.2.3.

\subsubsection{Fabricação por Camada Sacrificial}

Como o fotorresiste $A Z$ se mostrou inviável para ser usado como material de sacrifício, tentou-se realizar o processo utilizando o SU-8 tanto como material funcional como material de sacrifício.

Para se testar o método foi utilizado substrato de vidro e dois tipos diferentes de SU-8, SU-8 2005, que foi utilizado para adquirir espessuras em torno de $5 \mu \mathrm{m}$ e o SU-8 2000.5, que foi utilizado para obtenção de espessuras em torno de $0,5 \mu \mathrm{m}$.

O SU-8 2005 foi depositado sobre o substrato de vidro e então foi realizada a primeira cura (soft bake) a $95^{\circ} \mathrm{C}$ por 3 minutos. Então foi realizada a exposição a luz ultravioleta. Esta camada forma os postes do CMUT, ou seja, o material onde serão abertas as cavidades, portanto deve-se usar a máscara das cavidades nesta exposição. Assim, somente as regiões das cavidades devem ficar solúveis ao revelador. Após a exposição foi realizada a cura pós exposição (PEB) também a $95^{\circ} \mathrm{C}$ por 3 minutos. Sobre o SU-8 espesso (2005) é depositado uma camada de SU-8 fino (2000.5). É feito um novo soft bake, exposição com cerca de metade da dose da camada anterior e o PEB. Durante a exposição desta camada, é utilizada uma máscara para definição de furos de corrosão. Após a exposição o SU-8 ficaria solúvel apenas em regiões que formassem pequenos furos sobre a placa. Esses furos deveriam permitir que 0 revelador atingisse a camada de SU-8 espesso, que estaria solúvel na região das cavidades. Assim, retiraria o material da cavidade deixando as placas suspensas.

Entretanto, após a deposição do SU-8 fino, as regiões onde a camada espessa estava solúvel (sem exposição) apresentaram trincas na estrutura. Testes complementares indicaram que estava ocorrendo uma interação entre as duas fases do SU-8 (fase exposta e fase não exposta).

Então foi preparado um novo teste. Em vez de se depositar o SU-8 fino diretamente sobre a camada espessa, foi depositada uma camada de alumínio. Esse metal formaria os eletrodos superiores do dispositivo e 
foi depositado por evaporação térmica sobre a camada espessa de SU-8. Então deve ser feita uma litografia para abrir sobre esse eletrodo furos para penetração do revelador de SU-8. Com o SU-8 exposto nas regiões desses furos, o dispositivo é colocado no revelador. Assim o revelador deveria remover o SU-8 nas regiões das cavidades deixando a placa suspensa.

Ao se depositar o alumínio sobre o SU-8 espesso, foi observado que era possível distinguir as áreas expostas das áreas não expostas do SU-8. Observando ao microscópio foi possível perceber que as regiões não expostas ficaram enrugadas após o contato com o metal. Mesmo observando-se esse fato, foi dada sequência ao processo. Sobre a camada de alumínio foi depositada uma camada de SU-8 fino. Então foi realizado o soft bake utilizando menor tempo que o utilizado para a camada espessa. A dose de exposição também foi mais baixa reduzindo-se o tempo. O tempo de PEB também foi menor. Então foi realizada a revelação. Após a revelação a amostra é levada para solução de corrosão de alumínio, que é composta de $80 \mathrm{H}_{3} \mathrm{PO}_{4}+10 \mathrm{H}_{2} \mathrm{O}+5 \mathrm{HNO}_{3}$.

Durante a corrosão do Al a camada fina de SU-8 se soltou em diversas regiões do dispositivo. Assim a solução danificou regiões em que não deveria ter ocorrido corrosão.

Estes resultados indicam que alguns parâmetros precisam ser reconsiderados. O método não foi abandonado mas foram concentrados maiores esforços nos métodos de fabricação por colagem.

\subsection{Fabricação por Colagem}

Como já mencionado, no método de fabricação por colagem a base do CMUT e as placas são fabricados separadamente para posterior colagem. O processo se assemelha ao wafer bonding utilizado por Ergun et al. (2005) entretanto não utiliza silício nem processos como CVD ou difusão. Em vez disso foi utilizado substrato de vidro para a base e fotorresiste SU-8 como material do CMUT. O SU-8 é o material que sustenta a placa funcionando como postes. É nele que são abertas as cavidades que permitem que a placa vibre livremente. 


\subsubsection{Fabricação da Base}

O primeiro passo é a deposição do eletrodo inferior, que no caso deste trabalho é o eletrodo litografado. Foi depositado alumínio por evaporação térmica. Foi utilizada uma evaporadora de filamento modelo Auto 306 Edwards. O alumínio em forma de fio é cortado e colocado no filamento. As evaporações foram realizadas à pressão de $1 \times 10^{-12}$ Torr. A espessura da camada depositada foi de aproximadamente 600nm. Após a evaporação é realizada a litografia para definição dos eletrodos inferiores. Foi utilizada uma alinhadora modelo AL4-2. O fotorresiste utilizado é o AZ 1518 (positivo) utilizado-se camadas de aproximadamente $2 \mu \mathrm{m}$. A cura do fotorresiste é feita a $100^{\circ} \mathrm{C}$ por 55 segundos. Na revelação, é utilizado o revelador MIF 300 na proporção 4:1. Após a revelação, o alumínio é corroído com a solução $80 \mathrm{H}_{3} \mathrm{PO}_{4}+10 \mathrm{H}_{2} \mathrm{O}+5 \mathrm{HNO}_{3}$.

Com os eletrodos inferiores definidos é feita a deposição de SU-8 2005 para formação das cavidades. Esse tipo de SU-8 permite a obtenção de estruturas em torno de $5 \mu \mathrm{m}$ de espessura. Melhor controle da espessura é feito através da velocidade do spinner no memento da deposição. A maior parte das bases das amostras foram fabricadas utilizando-se uma camada de $5 \mu \mathrm{m}$ de SU-8. A primeira cura (soft bake) é feita a $95^{\circ} \mathrm{C}$ por 3 minutos. Então é realizada a exposição à luz ultravioleta e feita nova cura também a $95^{\circ} \mathrm{C}$ por 3 minutos. Então o SU-8 é revelado em revelador fornecido pelo fabricante $(\approx$ $1 \mathrm{~min})$. Isso encerra o processo de fabricação da base que é comum à maioria das amostras fabricadas por esse método. A medição das espessuras é feita através de um perfilômetro.

\subsubsection{Colagem da Placa}

A placa que deve ser colada sobre a base, geralmente precisa ser fabricada ou apoiada sobre outro substrato. Foram feitos diversos testes de fabricação com substratos de vidro tanto no LNLS quanto no LSI. A tentativa de se fabricar a placa de SU-8 sobre outro substrato de vidro ou acetato usando camada sacrificial de fotorresiste $A Z$, como descrito na seção 6.1, não apresentou resultados satisfatórios para fabricação de protótipos em número considerável. Optou-se então por se fabricar a placa utilizado-se um pedaço de folha de cobre. A chapa de cobre é cortada em tamanho apropriado e colocada numa solução de corrosão para reduzir sua espessura. Então esta chapa de cobre 
(a)

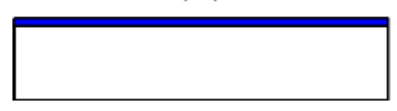

(d) (b)

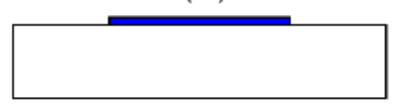

(e)
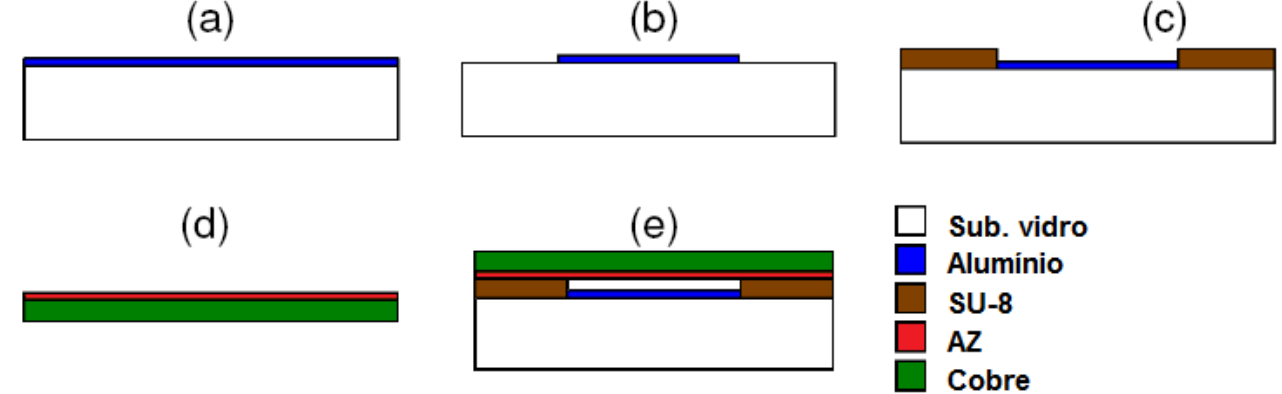

Figura 6.1: Processo de fabricação de CMUTs com placa de cobre por colagem.

é colada sobre a base utilizando SU-8 ou AZ.

Alguns substratos de vidro utilizados apresentaram dificuldades no momento do alinhamento da máscara das cavidades com a estrutura de eletrodos. Então o processo seguiu utilizando-se lâminas de microscópio como substrato da base por possuírem menor espessura.

\subsubsection{Protótipos com Placas de Cobre}

As primeiras tentativas de colagem da chapa de cobre sobre a base de SU-8 foram feitas depositando uma fina camada de SU-8 (SU-8 2000.5) sobre o cobre. Colocava-se a base e a chapa de cobre com SU-8 na chapa quente a $100^{\circ} \mathrm{C}$, com aproximadamente 20 segundos de aquecimento, a chapa de cobre era colocada sobre a base e um peso colocado sobre a chapa. $O$ conjunto permanece na chapa aquecedora por 30 minutos. Esta colagem entretanto não foi bem sucedida.

Foi realizada então uma nova tentativa de se colar a chapa de cobre usando fotorresiste AZ $1518 \mathrm{em}$ vez de SU-8. Foi depositada uma camada de $2 \mu \mathrm{m}$ de $A Z$. Então a colagem é feita durante o soft-bake da seguinte maneira: A chapa de cobre e a base são colocadas na chapa quente aquecida a $100^{\circ} \mathrm{C}$, após aproximadamente 40 segundos a chapa de cobre com AZ é colocada sobre a base e um peso é colocado em cima para fazer pressão. O conjunto então permanece sendo aquecido por 30 minutos. O processo é esquematizado na figura 6.1 .

Com esse processo foram obtidos os primeiros protótipos do método da colagem. Amostras obtidas por esse processo passaram por caracterização com medidor de impedância RCL. 
(a)

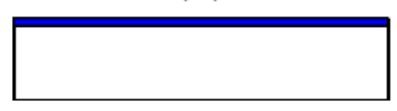

(d)

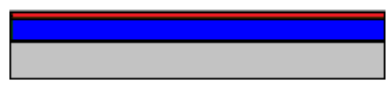

(b)

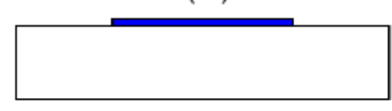

(e)

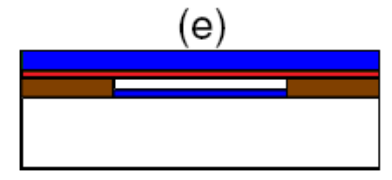

$\square$ sub. vidro
Aluminio
su-8
$\square$ AZ
$\square$ sub. silício

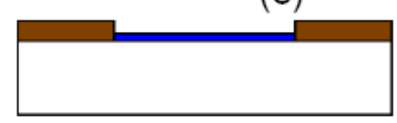

Figura 6.2: Processo de fabricação de CMUTs com placa de alumínio por colagem.

\subsubsection{Protótipos com Placas de Alumínio}

Ainda utilizando-se o método da colagem foram fabricados protótipos utilizando-se placas de folha de alumínio. A vantagem da folha de alumínio é que tem espessura muito menor que a folha de cobre utilizada no processo descrito anteriormente. Entretanto, há maior dificuldade em se trabalhar com esse material justamente devido a sua baixa espessura.

A base do CMUT foi fabricada sobre substrato de vidro tendo postes de SU-8 como no processo anterior. Sobre a base então é colada a folha de alumínio (6.2).

Para sustentação da folha de alumínio durante a fabricação foi utilizada um lâmina de silício. A folha de alumínio foi esticada sobre a lâmina de Si. Então é depositada uma camada de $2 \mu \mathrm{m}$ de fotorresiste $\mathrm{AZ}$ sobre a folha de $\mathrm{Al}$. Então, tanto a base do CMUT quanto a lâmina contendo a folha de alumínio são levadas à chapa quente aquecida a $100^{\circ} \mathrm{C}$. Com aproximadamente 20 segundos de aquecimento, a base é apoiada de ponta cabeça sobre a folha de Al contendo a camada de AZ. Coloca-se sobre o conjunto um peso de metal para fazer pressão e auxiliar na colagem. Então é realizada uma cura de 30 minutos. Após a cura o conjunto é retirado da chapa quente e a folha de alumínio é recortada manualmente. Essas amostras também passaram por caracterização com medidor RCL.

\subsection{Considerações sobre processo de fabricação}

Neste capítulo foram descritas diversas técnicas para a fabricação de CMUTs. Foram feitas diversas tentativas por diferentes métodos utilizando 
os equipamentos disponíveis nos dois laboratórios de microfabricação a que o grupo tem acesso (LSI-EPUSP e LNNANO). Inicialmente, foram feitas inúmeras tentativas no LNNANO utilizando o método de camada sacrificial. Entretanto, esse método se mostrou inviável até o momento. Novas tentativas, com algumas modificações, poderão ser realizadas em trabalhos futuros.

Por outro lado, o método de fabricação de duas partes separadas e posterior colagem ("bonding") apresentou ótimos resultados, possibilitando a preparação de diversos protótipos de CMUTs para testes. Como simplicidade no processo de fabricação também é um dos objetivos do trabalho, optou-se por métodos de colagem. Durante os diversos testes de fabricação realizados, foi observado que há boa aderência entre os fotorresistes SU-8 e AZ. Isso auxiliou na fabricação permitindo a colagem da base (eletrodos inferiores e cavidades) à placa. $O A Z$ foi utilizado para colar as placas flexíveis aos postes de SU-8. Assim foram fabricados protótipos com placas de alumínio e protótipos com placas de cobre. Os dois processos apresentam poucas diferenças e os dois metais têm bom potencial de aplicação.

As tentativas de fabricação, bem como os resultados de simulações também resultaram em publicações para o grupo ((OLIVEIRA et al., 2012, 2011)). 


\section{Procedimentos de caracterizações}

Este capítulo descreve os procedimentos e aparatos utilizados nas caracterizações do CMUT.

\subsection{Medições de propriedades dielétricas}

Os protótipos passaram por caracterização elétrica utilizando-se um medidor de impedância. O instrumento utilizado é um modelo "PM6306 progabale automatic RCL meter" da marca Fluke. Este instrumento permite realizar medições de propriedade dielétricas na faixa de frequência de $200 \mathrm{~Hz}$ a 1 $\mathrm{MHz}$. Realiza medições utilizando tensões alternadas de $50 \mathrm{mV}$ a 2 V. Durante as medições, pode aplicar tensões continuas de até $10 \mathrm{~V}$ interna e de até 40 $V$ se conectado a uma fonte externa. Os primeiros ensaios basearam-se no levantamento de curvas de propriedades dielétricas variando-se a frequência. As principais propriedades medidas foram impedância, capacitância e ângulo de fase. Estes ensaios tiveram o objetivo de verificar o comportamento capacitivo dos dispositivos fabricados e sua funcionalidade. Não foram utilizados nestes ensaios circuitos adicionais.

O medidor RCL foi utilizado ainda para levantamento das propriedade dielétricas do CMUT quando submetido a uma carga mecânica.

\subsection{Montagens para caracterizações elétricas do CMUT}

Para que o CMUT opere adequadamente, é necessário que haja polarização de seus eletrodos. Isso é feito através de uma tensão contínua que pode 
ser relativamente alta dependendo das características do CMUT e do modo de operação. Essa tensão contínua induz cargas nos eletrodos dos CMUTs. Como os eletrodos superiores são placas flexíveis, essas cargas tendem a forçá-las em direção aos eletrodos inferiores causando deflexão. Isso faz com que as placas fiquem sob um estado de pré-tensão como uma mola tensionada mudando sua posição de equilíbrio. A partir dessa posição de equilíbrio causada pela polarização, a placa poderá vibrar quando excitada. A excitação pode ser através de um sinal de tensão alternada, no caso de operação como emissor ou uma onda mecânica no caso de operação em modo receptor. Assim, para operação no modo emissor, além da polarização, o circuito também precisa ser capaz de fornecer um sinal alternado. Já o modo receptor só exigem tensão contínua para aproximar as placas. Não é necessária a parte alternada do sinal pois o que faz o CMUT vibrar neste caso são ondas recebidas pela placa flexível. Mas neste caso, também são necessários componentes que tornem possível a aquisição de um sinal de corrente induzida pela vibração do CMUT devido à excitação de suas placas por uma onda.

Inicialmente, foram fabricados circuitos retificadores de onda completa para obtenção da tensão contínua. Estes circuitos foram usados em diferentes montagens que são capazes de fornecer tensões continuas de centenas de volts e tensões alternadas de 0 a $10 \mathrm{~V}$ de pico.

Na montagem da figura 7.1 é utilizado um circuito retificador de onda completa em conjunto com um transformador com saída variável. Isso possibilita obter uma boa faixa de tensões de operação. A parte alternada do sinal é obtida utilizando-se um gerador de funções. Este arranjo permite um bom controle tanto da tensão contínua como da alternada. Em alguns testes o gerador de funções foi substituído por circuito utilizando oscilador 555.

\subsection{Montagens para medições com tensão de polarização}

A fim de facilitar e tornar mais praticas as caracterizações elétricas, foram construídos suportes como o da figura 7.2 para colocar as amostras e conectá-las aos demais componentes do circuito. Estes suportes foram feitos de placas de circuito impresso. Uma das faces possui trilhas que permitem 


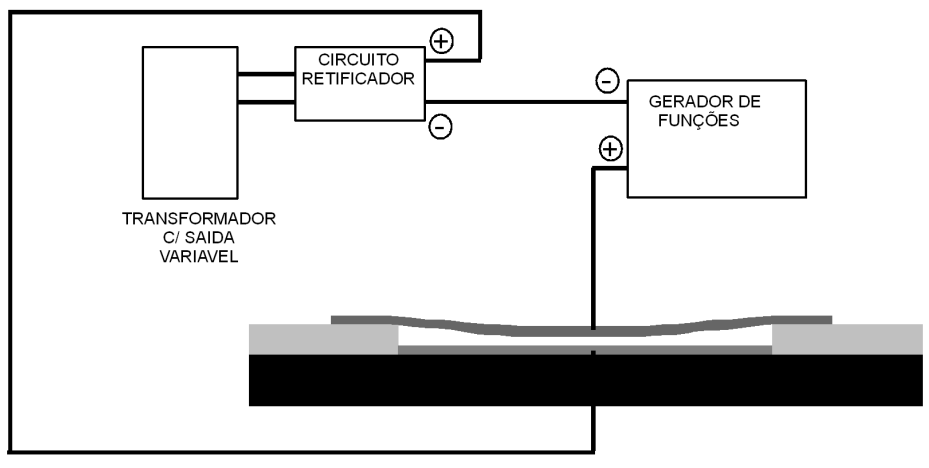

Figura 7.1: Esquema de ligação do CMUT para operação como emissor.

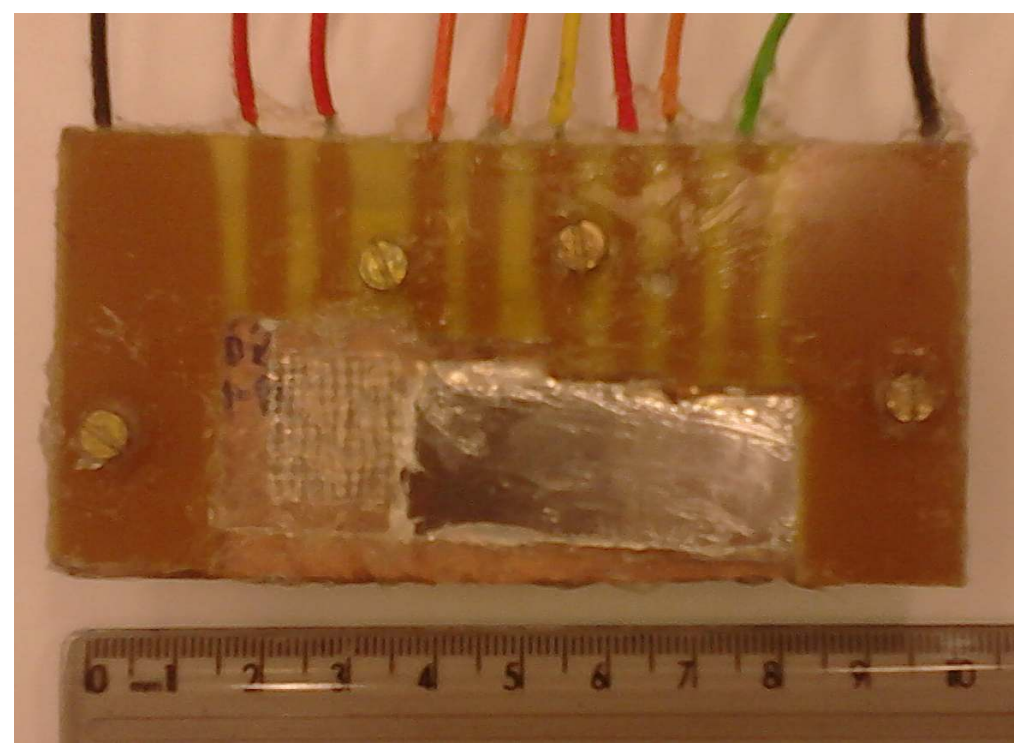

Figura 7.2: Amostras de CMUTs presas a um suporte de placa de circuito impresso.

contato com os pads dos CMUTs. Fios soldados nestas trilhas permitem a conexão com o restante do circuito. Assim foi possível realizar conexões mais estáveis.

Foram estudados diversos arranjos de circuitos para as caracterizações elétricas. O nível de ruído gerado pelos circuitos de medição é uma questão que merece atenção.

Durante os testes foi observado que o modo receptor é mais crítico que o emissor uma vez que o sinal gerado tem amplitude muito baixa (da ordem de alguns milivolts). Ruídos oriundos do circuito são altamente prejudiciais às medições. Então foram utilizados circuitos amplificadores para elevar o nível do sinal gerado pelo CMUT quando excitado por ondas no modo receptor, como ilustrado na figura 7.3. Também foram feitos testes com diferentes tensões de polarização a fim de se encontrar a mais adequada para cada 
amostra do CMUT.

Outro artifício utilizado para minimizar os efeitos de ruídos foi utilizar baterias em vez de circuito retificador. Além disso trabalhar com baterias dá boa praticidade aos experimentos. Desta maneira, a variação da tensão de polarização se dá de 12 em 12 V.

A alta voltagem é uma preocupação pois pode danificar equipamentos e componentes eletrônicos utilizados durante as caracterizações. A fim de prevenir esse tipo de transtorno, foram incorporados aos aparatos de medição, circuitos de proteção. Os principais componentes utilizados nos circuitos de proteção foram fusíveis, capacitores e diodos.

\subsubsection{Piezo emissor e CMUT receptor}

O circuito da figura 7.3 foi montado para trabalhar com o CMUT em modo receptor. Os ensaios realizados consistiram em excitar um atuador piezoelétrico e aproximá-lo do CMUT de maneira a emitir suas ondas em direção as placas flexíveis através do ar (fig. 7.4). Devido a excitação de um sinal CA, a cerâmica piezoelétrica vibra emitindo ondas que se propagam pelo ar e chegam às placas do CMUT percorrendo uma distância da ordem de milímetros. Circuitos amplificador geralmente são necessários pois o sinal emitido do CMU é muito baixo. O circuito permitiu que o CMUT fosse polarizado com tensões CC da ordem de $100 \mathrm{~V}$ ao mesmo tempo que evita que esta tensão chegue a componentes que não a suportariam. O sinal de saída passa pelo circuito amplificador e é analisado por um osciloscópio. Circuitos semelhantes são utilizados por outros pesquisadores (CARONTI et al., 2004).

\subsubsection{Varredura de frequência usando tensão de polarização}

Utilizando circuito de proteção, foram realizadas varreduras das propriedades dielétricas do CMUT para diferentes tensões de polarização. Nestas medições também foi utilizado o medidor de impedância PM6306. O instrumento tem capacidade de aplicar tensão de bias (polarização) de $10 \mathrm{~V}$ interna e até $40 \mathrm{~V}$ externa através da conexão de outro equipamento. Isso causaria uma limitação quanto à polarização do CMUT dificultando seu adequado 


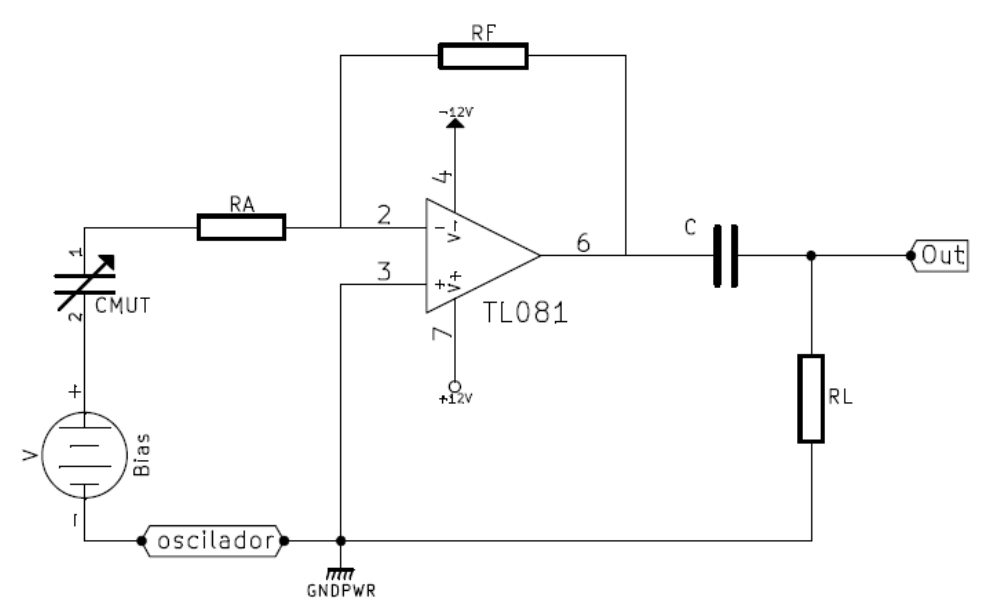

Figura 7.3: Circuito amplificador utilizado para CMUT em modo receptor.

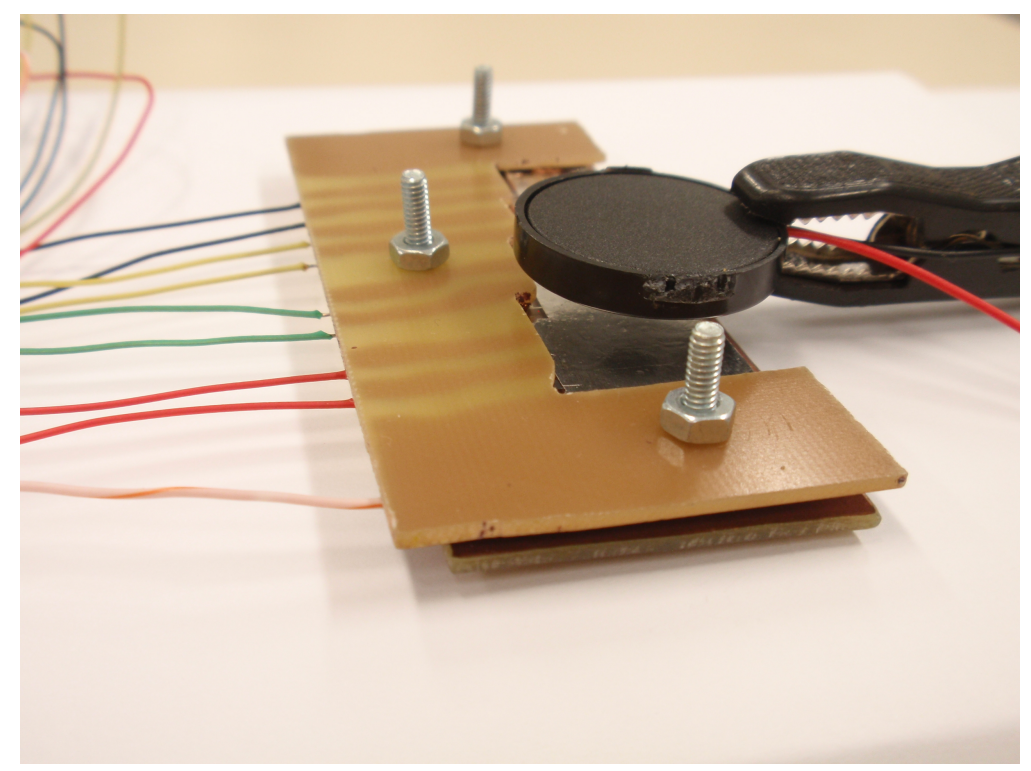

Figura 7.4: Aparato utilizando transdutor piezoelétrico como emissor e CMUT como receptor. 


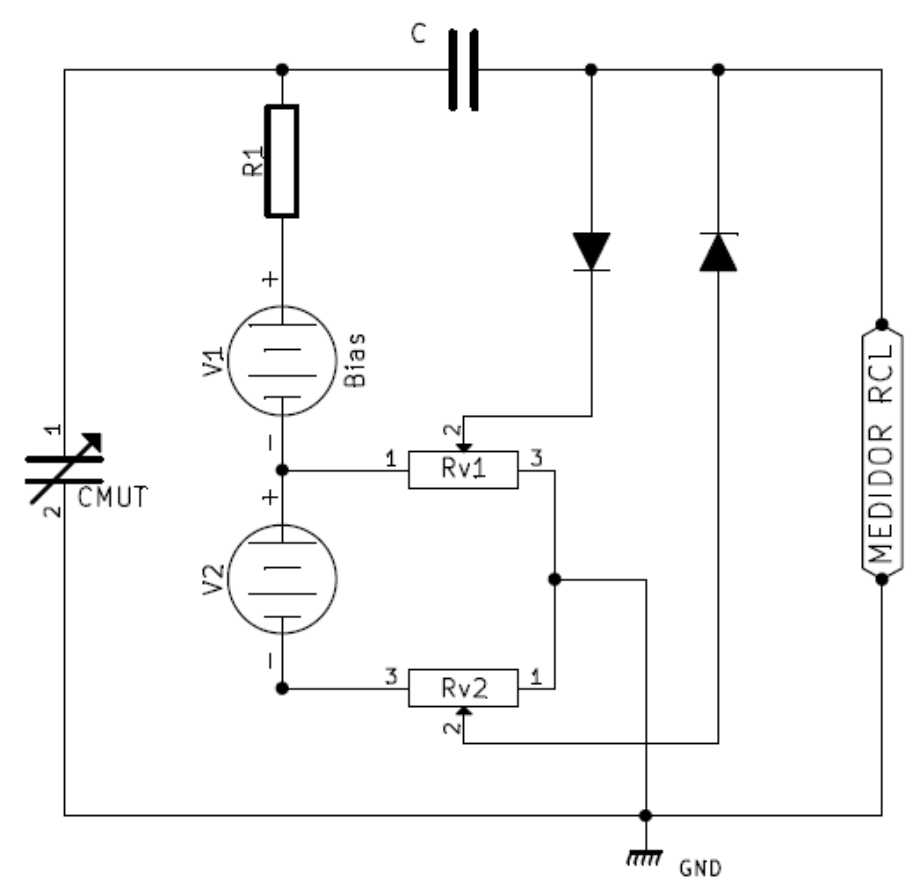

Figura 7.5: Circuito clipper utilizado para polarizar CMUT e proteger medidor RCL.

funcionamento. Por isso o CMUT precisou ser ligado a um circuito externo para que fosse polarizado. O circuito, que polariza o CMUT ao mesmo tempo que protege o instrumento de medição contra tensões e corrente seja contínua ou transiente, pode ser visto na figura 7.5. O instrumento de medição pode ser programado e controlado diretamente por um computador possibilitando fazer medições rapidamente. Foram feitas desta maneira, varreduras das propriedades dielétricas de diferentes CMUTs numa determinada faixa de frequências. Os resultados das medições são apresentados no próximo capítulo. 


\section{Resultados e Discussões}

\subsection{Resultados da fabricação}

Foram fabricadas amostras utilizando-se diferentes materiais, dimensões e métodos. Todas foram fabricadas sobre substrato de vidro e possuem postes de SU-8. Entretanto, há diferenças no material das placas flexíveis e no tipo de SU-8 utilizado. Essas amostras foram nomeadas seguindo um padrão baseado no material, dimensões dos CMUTs e posição no substrato. A figura 8.1 mostra um substrato de vidro com CMUTs de placas de cobre. Há quatro estruturas (CMUTs), sendo que as duas do lado direito estão completas com as placas de cobre e as outras duas ficaram inacabadas (sem as placas de cobre). Já a figura 8.2, mostra um substrato de vidro com três CMUTs de placas de alumínio. O eletrodo superior é comum a todos CMUTs do substrato, mas o inferior é separado. Cada array possui dois conjuntos de eletrodos inferiores.

Cada CMUT é um array $10 \times 10$ totalizando 100 placas flexíveis. Cada um dos pads vistos em cada array acesssa metade dos eletrodos inferiores. A diferença de potencial é aplicada entre um pad e a placa para utilizar metade do array. Aplicando-se a ddp entre a placa e os dois pads, utiliza-se todo o array. Para facilitar a identificação, as estruturas foram nomeadas, recebendo no nome uma letra $\mathbf{C}$ para cobre e $\mathbf{A}$ para alumínio acompanhada de um número. Em seguida uma letra $\mathbf{E}$ acompanhada de um número que indica a posição da estrutura ( 1 a 4) da maior para a menor. Assim a maior estrutura que aparece na figura 8.1 é C1E1. A tabela 8.1 mostra a identificação e as dimensões das principais amostras. Nas próximas seções são mostrados resultados das caracterizações das amostras. 
Tabela 8.1: Dimensões das amostras fabricadas e caracterizadas.

\begin{tabular}{|llll|}
\hline Amostra & $\begin{array}{l}\text { Material da } \\
\text { placa flexível }\end{array}$ & $\begin{array}{l}\text { Profundidade } \\
\text { da cavidade } \\
(\mu \mathrm{m})\end{array}$ & $\begin{array}{l}\text { Diâmetro da } \\
\text { placa }(\mu \mathrm{m})\end{array}$ \\
\hline C1E1 & Cobre & 5 & 1000 \\
C1E2 & Cobre & 5 & 800 \\
A1E1 & Alumínio & 5 & 1000 \\
A1E2 & Alumínio & 5 & 800 \\
A2E1 & Alumínio & 5 & 1000 \\
A2E2 & Alumínio & 5 & 800 \\
A3E1 & Alumínio & 0,5 & 1000 \\
A3E2 & Alumínio & 0,5 & 800 \\
\hline
\end{tabular}

\subsection{Resultados de medições RCL}

Os gráficos das figuras 8.3 a 8.5 mostram curvas da impedância, capacitância e ângulo de fase para CMUTs com placas de cobre. Foi utilizado um sinal $\mathrm{CA}$ de $500 \mathrm{mV}$ gerado pelo equipamento. Foram levantados dados com e sem acréscimo de tensão bias CC de 2 a 10V (tensão de polarização). A tensão CC tem o objetivo de aproximar a placa flexível do eletrodo inferior. A faixa de frequência utilizada foi de $200 \mathrm{~Hz}$ a $1 \mathrm{MHz}$ sendo que para os valores mais baixos de frequência (centenas de $\mathrm{Hz}$ ), o dispositivo não apresentava comportamento capacitivo. Por isso foram plotados dados para frequências a partir de $5 \mathrm{kHz}$.

A amostra utilizada na medição tem um array com 100 placas circulares com espessura de $30 \mu \mathrm{m}$. A cavidade tem $5 \mu \mathrm{m}$ de profundidade e $800 \mu \mathrm{m}$ de diâmetro.

Essas curvas também foram levantadas para os protótipos com placa de alumínio. Sendo que foram utilizados protótipos com duas profundidades de cavidade diferentes. Foi utilizada tensão CA de $500 \mathrm{mV}$ e foram levantadas curvas com e sem tensão de Bias CC . As figuras 8.6 a 8.8 mostram a impedância, a capacitância e o ângulo de fase para um protótipo com cavidade de $5 \mu \mathrm{m}$ de profundidade. Esse protótipo apresenta um array de 100 placas, mas as curvas foram levantadas utilizando apenas metade delas. O diâmetro das placas é de $1000 \mu \mathrm{m}$.

As figuras 8.9 a 8.11 mostram as curvas para uma amostra também de alumínio com 100 placas (50 utilizadas) mas com alguns parâmetros diferentes. O diâmetro das placas é $800 \mu \mathrm{m}$ e a profundidade da cavidade é 


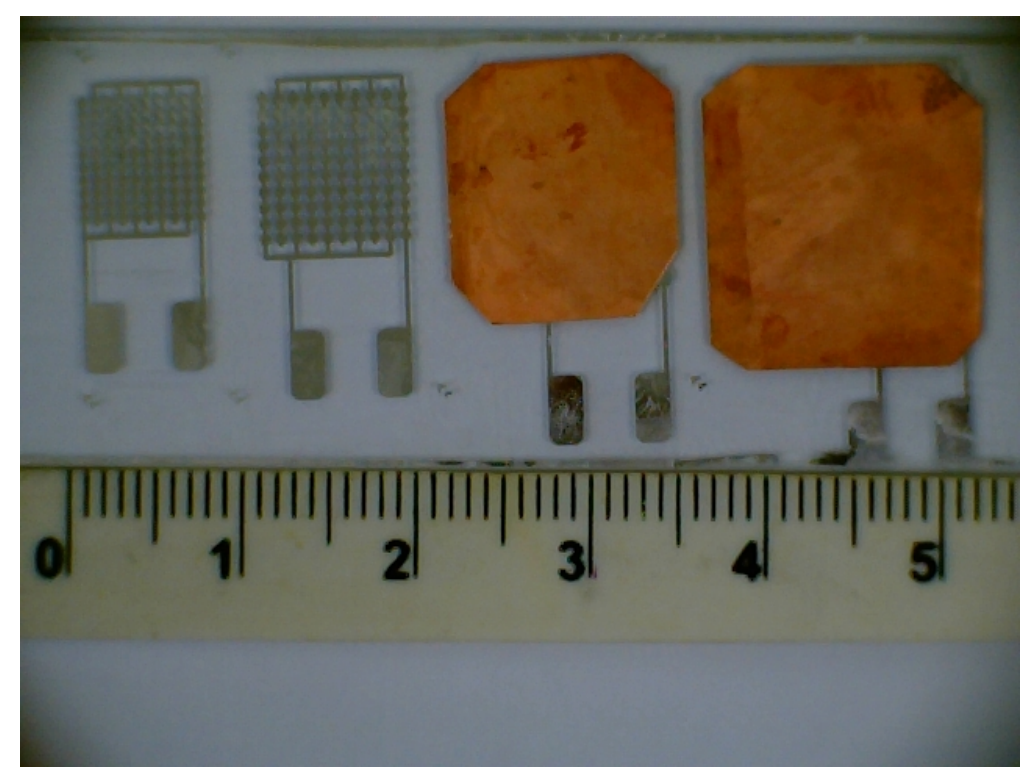

Figura 8.1: Protótipo de CMUT com placas de cobre.

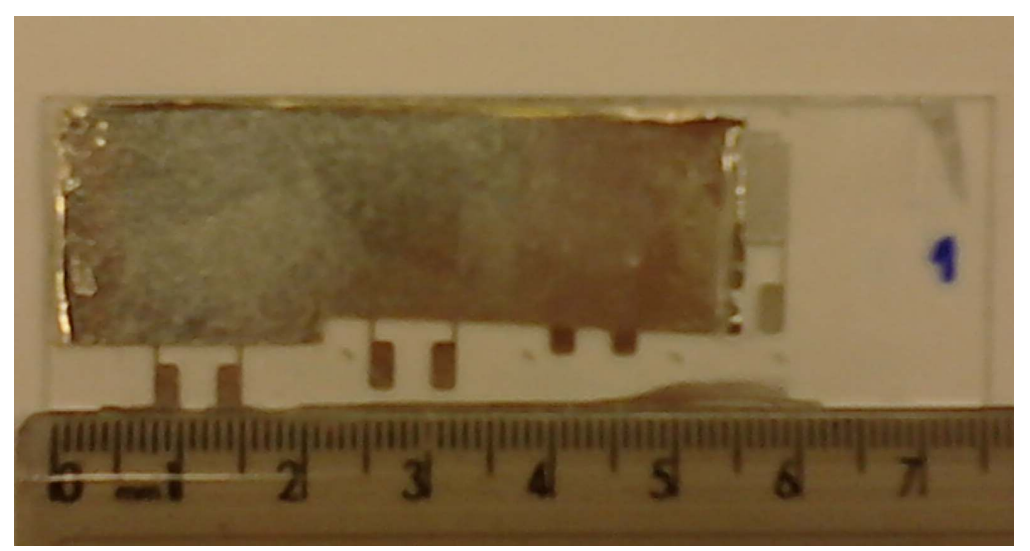

Figura 8.2: Protótipo de CMUT com placas de alumínio.

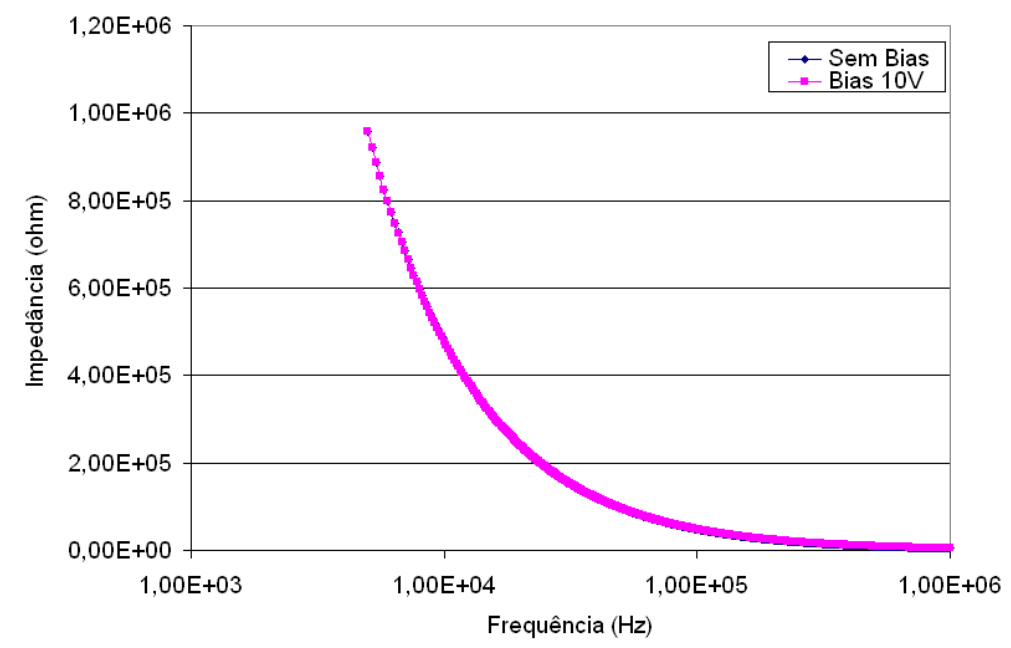

Figura 8.3: Curva de impedância em função da frequência para CMUT com placas de cobre. 


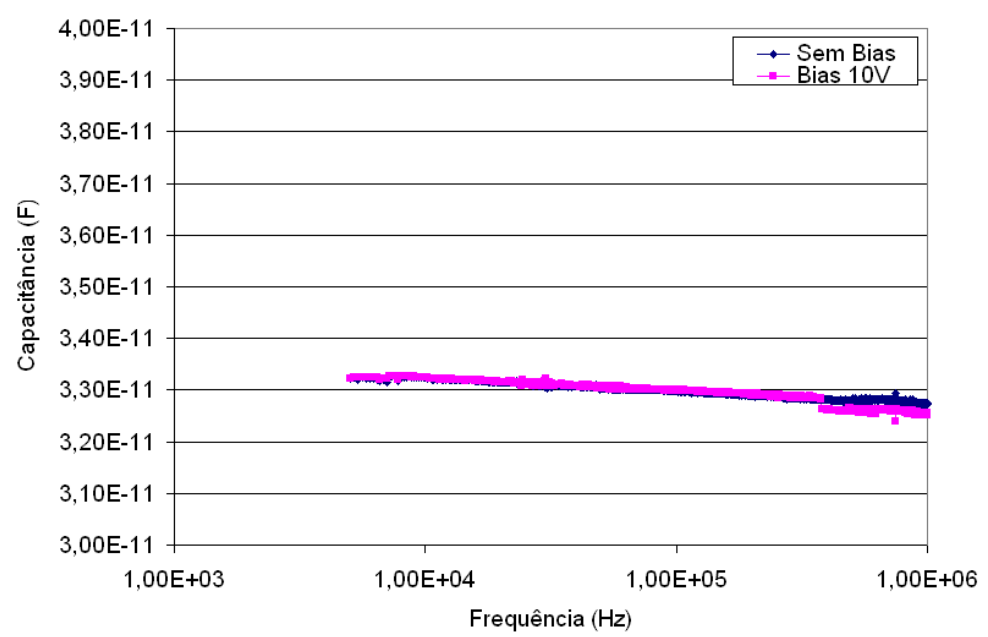

Figura 8.4: Curva de capacitância em função da frequência para CMUT com placas de cobre.

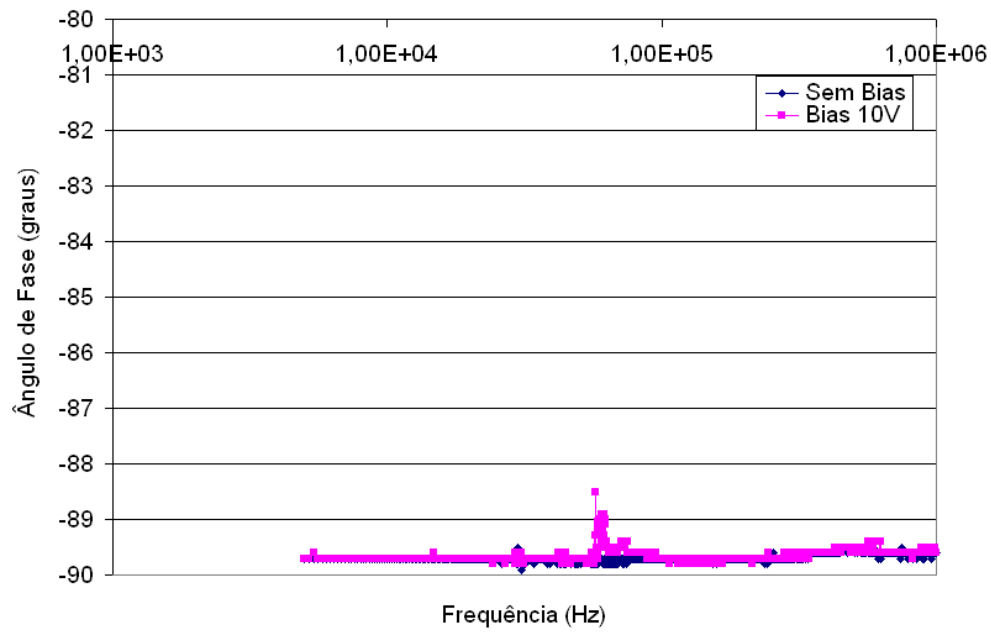

Figura 8.5: Curva do ângulo de fase em função da frequência para CMUT com placas de cobre.

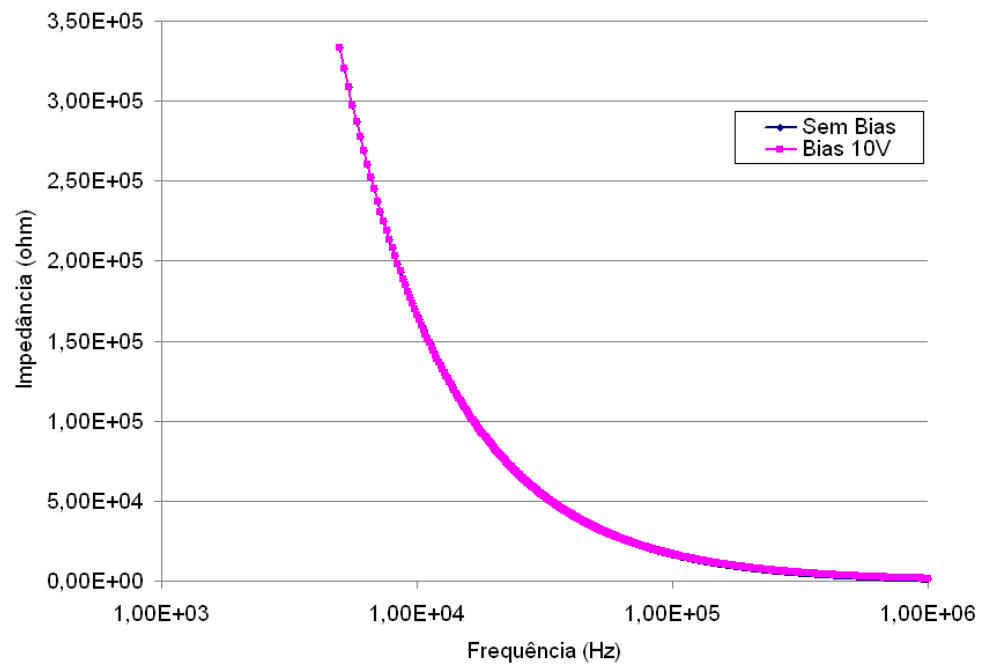

Figura 8.6: Curva de impedância em função da frequência para CMUT com placas de alumínio com cavidade de $5 \mu \mathrm{m}$. 


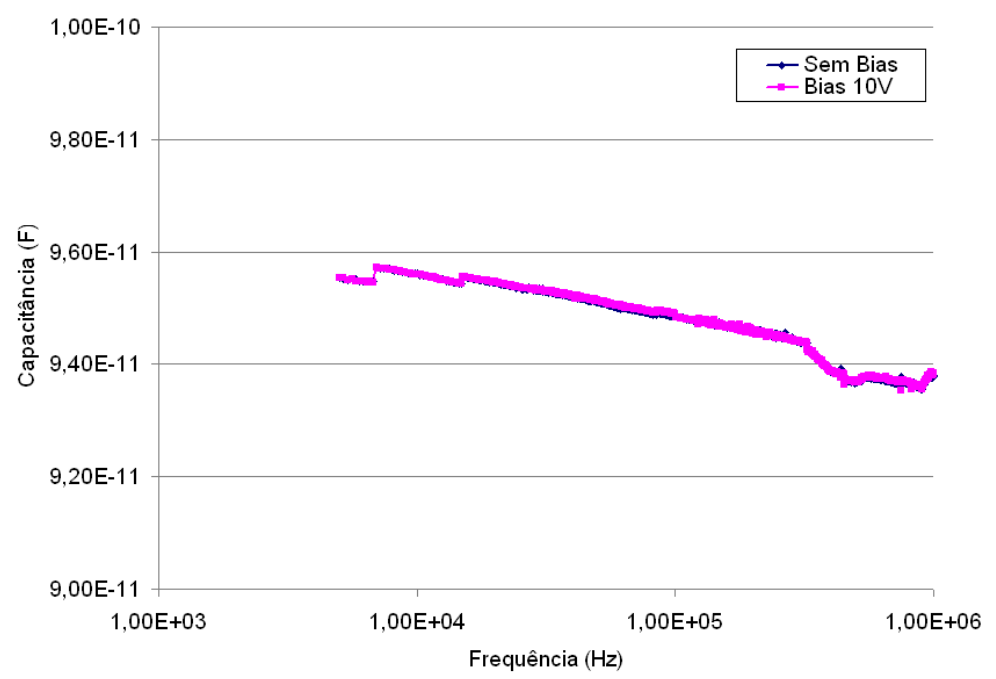

Figura 8.7: Curva de capacitância em função da frequência para CMUT com placas de alumínio com cavidade de $5 \mu \mathrm{m}$.

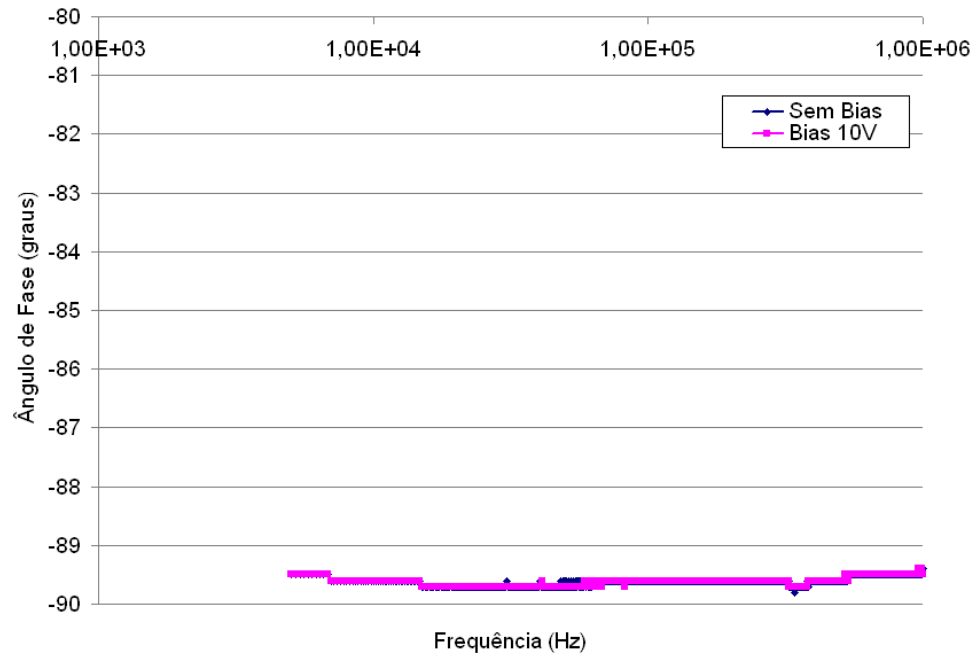

Figura 8.8: Curva do ângulo de fase em função da frequência para CMUT com placas de alumínio com cavidade de $5 \mu \mathrm{m}$. 


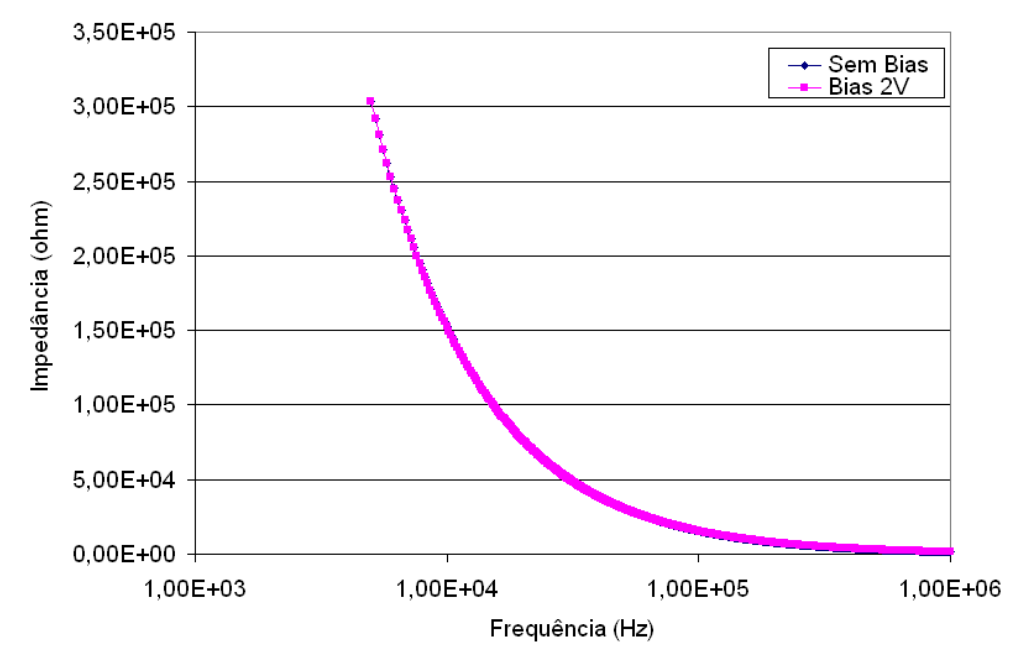

Figura 8.9: Curva de impedância em função da frequência para CMUT com placas de alumínio com cavidade de $0,5 \mu \mathrm{m}$.

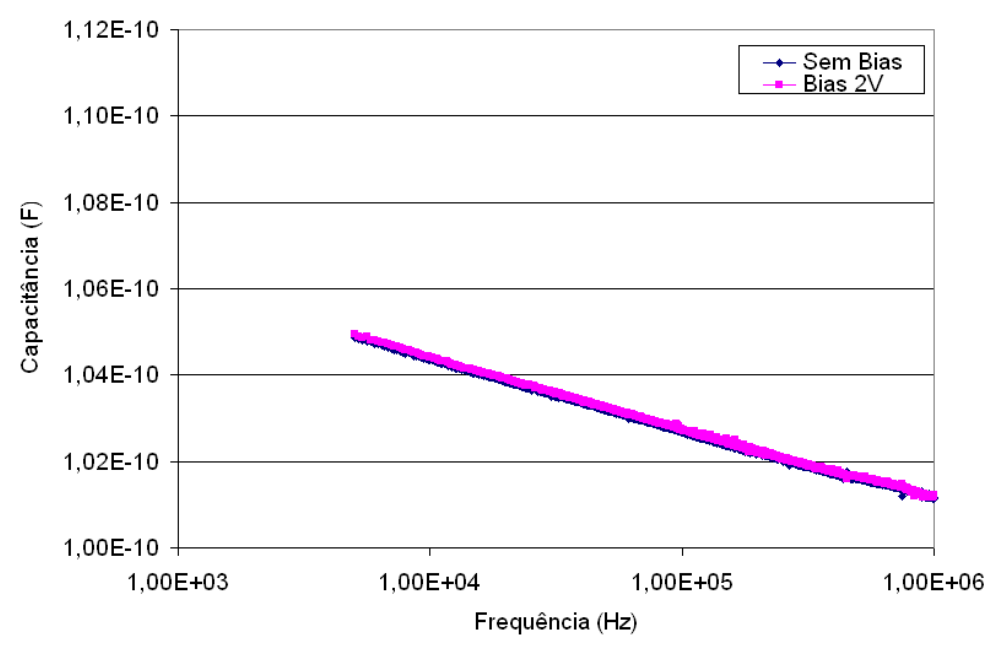

Figura 8.10: Curva de capacitância em função da frequência para CMUT com placas de alumínio com cavidade de 0,5 $\mu \mathrm{m}$

$0,5 \mu \mathrm{m}$. Testes anteriores a aquisição destas curvas mostraram que amostras com essa profundidade de cavidade não suportam tensões CC tão altas quanto as demais. Por isso foi utilizada tensão CC de apenas 2V.

Pelo comportamento das curvas da impedância e capacitância que caem com o aumento da frequência e do ângulo de fase que não sofre grandes variações, nota-se que o dispositivo realmente apresenta características de um capacitor. A aplicação de baixas tensões CC durante a medição não alterou significativamente os resultados indicando que os níveis de tensão aplicados não foram suficientes para fletir a placa. Resultados com tensões mais elevadas serão vistos mais adiante.

Um outro ensaio foi realizado para fletir a placa mecanicamente e verificar 


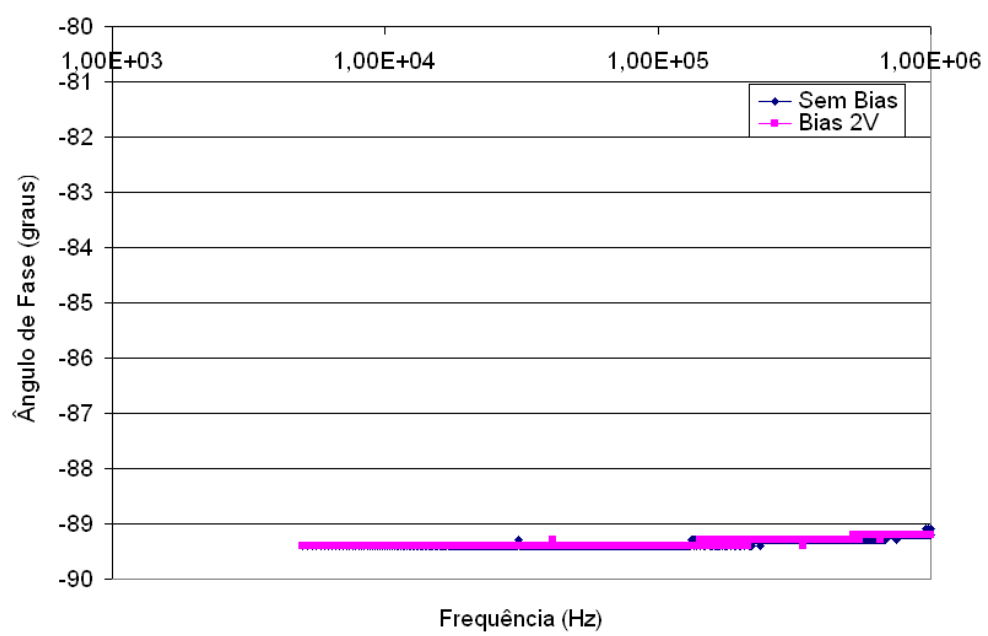

Figura 8.11: Curva do ângulo de fase em função da frequência para CMUT com placas de alumínio com cavidade de $0,5 \mu \mathrm{m}$.

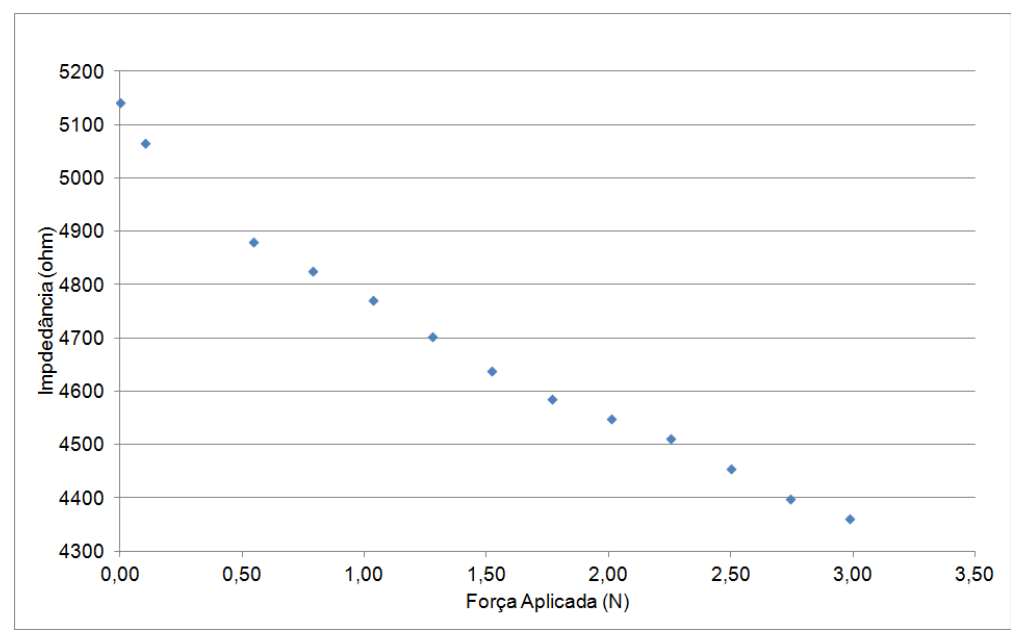

Figura 8.12: Curva de variação da impedância em função de uma força aplicada para CMUT com placas de alumínio com cavidade de $5 \mu \mathrm{m}$.

os parâmetros variáveis. Neste ensaio foram utilizados protótipos com placas de alumínio. As figuras 8.12 a 8.14 mostram a variação na impedância, capacitância e ângulo de fase para um protótipo com cavidade de $5 \mu \mathrm{m}$ de profundidade.

As figuras 8.15 a 8.17 mostram a variação na impedância, capacitância e ângulo de fase para um protótipo com cavidade de $0,5 \mu \mathrm{m}$ de profundidade.

Os resultados dessa análise mostram que o CMUT é sensível á aplicação de uma força. $O$ efeito é percebido na variação da impedância que cai com o aumento da carga e na capacitância que aumenta. Isso indica que a distância entre os eletrodos inferiores e superiores está diminuindo. As duas amostras utilizadas apresentaram sensibilidade semelhante nesta análise. Tanto a impedância quanto a capacitância apresentaram variação total em 


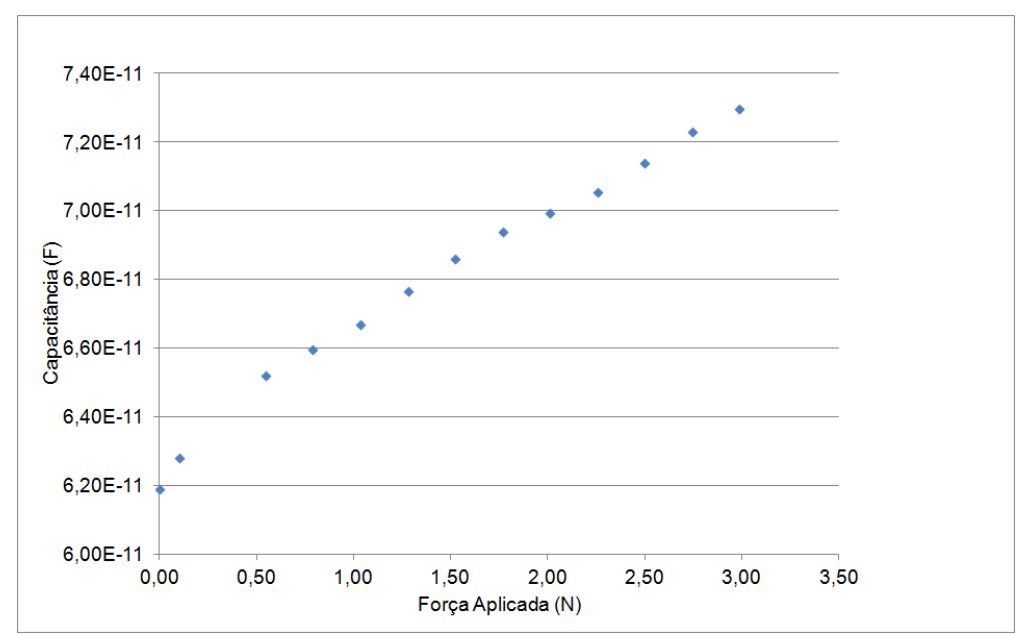

Figura 8.13: Curva de variação da capacitância em função de uma força aplicada para CMUT com placas de alumínio com cavidade de $5 \mu \mathrm{m}$.

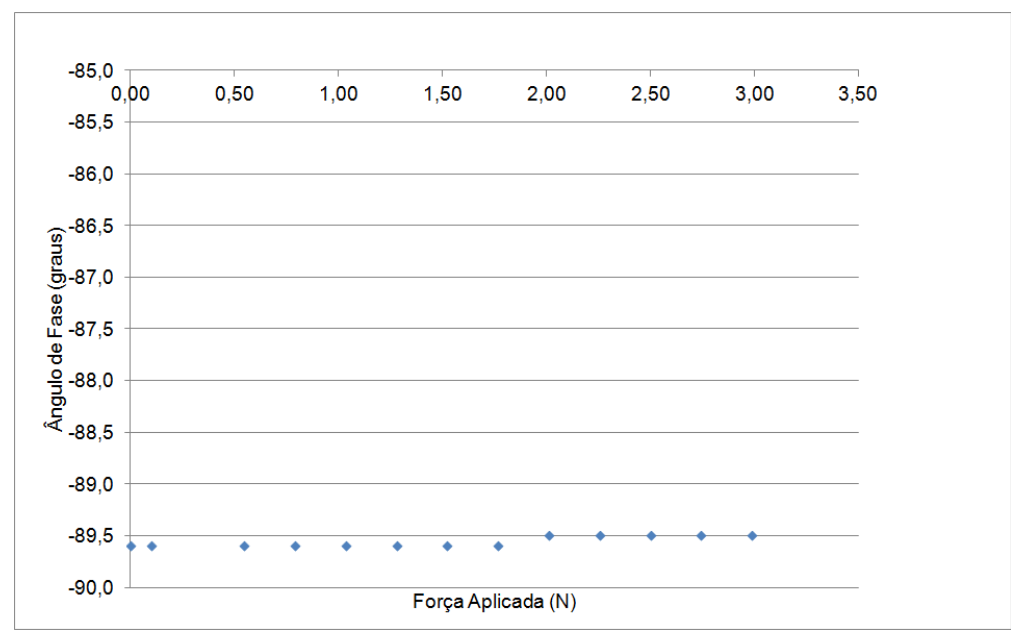

Figura 8.14: Curva variação do ângulo de fase em função de uma força aplicada para CMUT com placas de alumínio com cavidade de $5 \mu \mathrm{m}$.

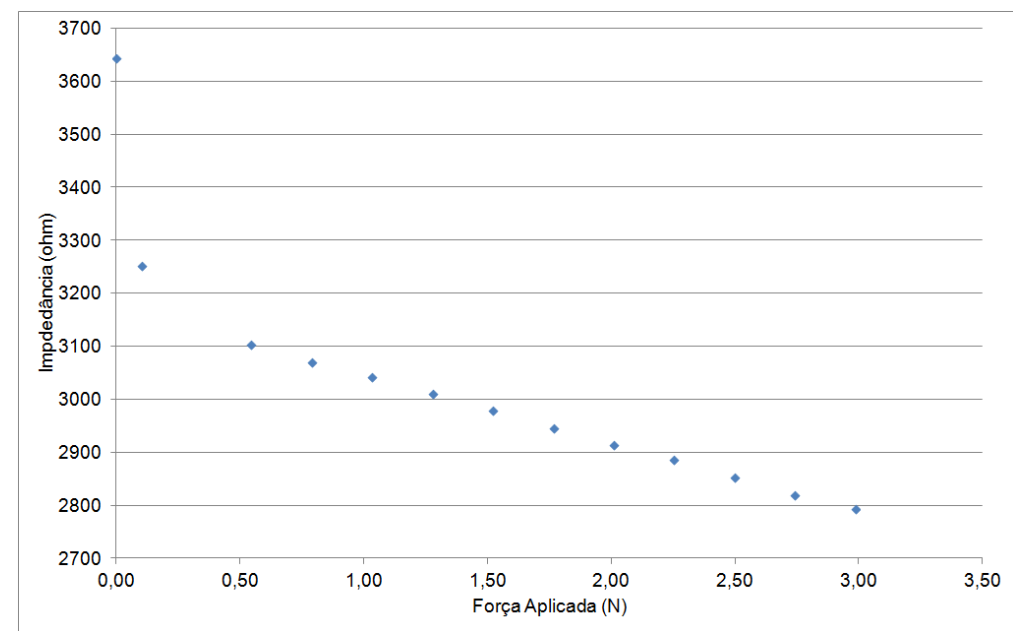

Figura 8.15: Curva de variação da impedância em função de uma força aplicada para CMUT com placas de alumínio com cavidade de $0,5 \mu \mathrm{m}$. 


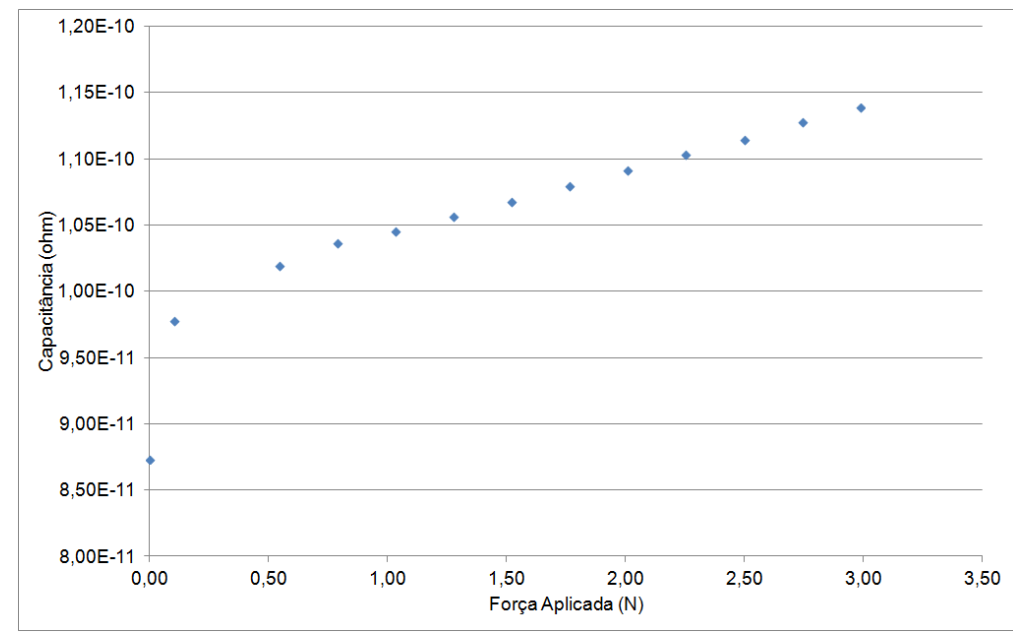

Figura 8.16: Curva de variação da capacitância em função de uma força aplicada para CMUT com placas de alumínio com cavidade de $0,5 \mu \mathrm{m}$.

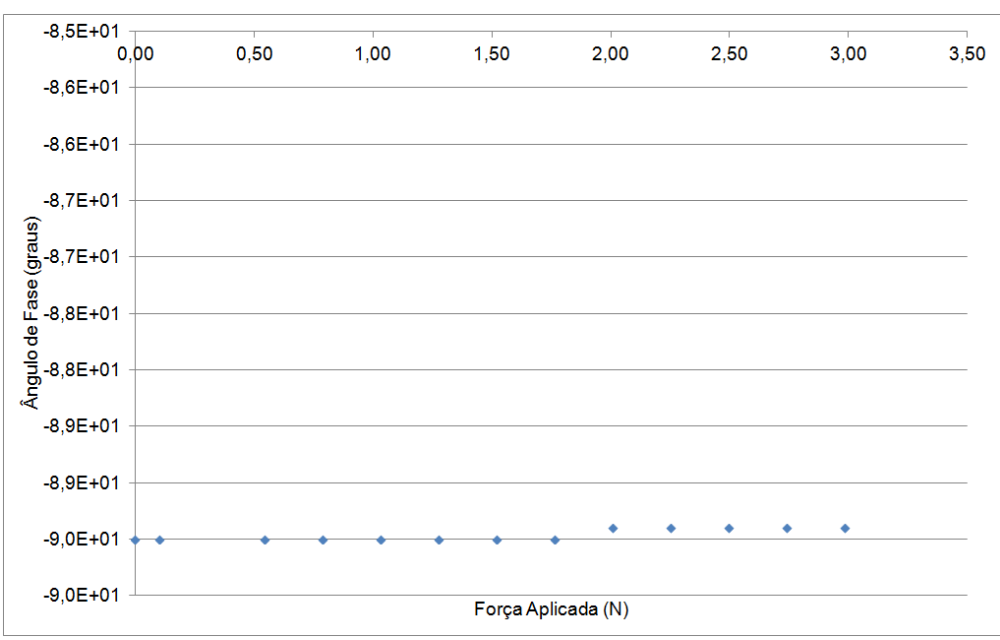

Figura 8.17: Curva variação do ângulo de fase em função de uma força aplicada para CMUT com placas de alumínio com cavidade de $0,5 \mu \mathrm{m}$. 
torno de $15 \%$ tanto para a amostra de $5 \mu \mathrm{m}$ quanto para a amostra de $0,5 \mu \mathrm{m}$. As amostras de profundidade $0,5 \mu \mathrm{m}$ precisam ser utilizadas com cautela, pois apresentaram o problema de não resistir à tensões CC um pouco mais elevada entrando em curto e sendo inutilizadas. O ângulo de fase não sofre variações significativas indicando que o dispositivo não perdeu suas propriedades capacitivas durante o experimento, não havendo curto-circuito ou rompimento de dielétrico.

\subsection{Resultados de medições utilizando circuitos adicionais}

Através das medições com circuito retificador em conjunto com gerador de funções, foi possível perceber o CMUT operando em modo emissor. Foram utilizadas amostras com placas de alumínio com cavidades de $5 \mu \mathrm{m}$ de profundidade. O diâmetro varia de amostra para amostra sendo de 600, $800 \mathrm{e}$ $1000 \mu \mathrm{m}$. Foi observado que com a aplicação de tensão CC combinada com um sinal alternado do gerador funções em frequência audível, o dispositivo produz som. O som produzido pelo CMUT varia com a frequência do sinal alternado. Utilizou-se tensões constantes de 0 a $130 \mathrm{~V}$ e tensões alternadas de 0 a $10 \mathrm{~V}$. A partir destes resultados foram montados novos circuitos.

Experimentos para testar o modo receptor foram realizados utilizando o circuito amplificador. Os experimentos foram realizados excitando-se 0 piezoelétrico de duas maneiras, utilizando circuito oscilador com Cls 555 e também utilizando um gerador de funções para enviar sinais em diferentes frequências.

Este experimento permitiu constatar o funcionamento do CMUT como receptor em frequências audíveis. O experimento consiste basicamente em fazer chegar ao CMUT uma onda vinda do transdutor piezoelétrico passando pelo ar. Para isso o transdutor piezoelétrico foi excitado com um sinal senoidal vindo do gerador de funções apontado para o CMUT polarizado. Então, o sinal gerado pelo CMUT é analisado pelo osciloscópio.

Os protótipos utilizados neste experimento possuem cavidade de $5 \mu \mathrm{m}$ de espessura e placas de alumínio de $10 \mu \mathrm{m}$ de espessura. Os diâmetros das placas são diferentes $(600,800$ e $1000 \mu \mathrm{m})$.

Em determinadas frequências dentro da faixa audível, o CMUT gerou sinal 
bem definido visto pelo osciloscópio. Foi observado um sinal CA na saída do circuito de medição. As frequências com melhor sinal foram em torno de 2,1; 3,7; 5,6; e $6,5 \mathrm{kHz}$. O sinal mais forte foi em $3,7 \mathrm{kHz}$. A amplitude do sinal ficou em torno de 75 a $103 \mathrm{mV}$. Os CMUTs com placas de maior diâmetro apresentaram sinal com amplitude sensivelmente maior que os CMUTs de menor diâmetro. Quanto as frequências de operação, não foram observadas variações significativas relacionadas ao diâmetro nesta faixa.

\subsubsection{Resultados de varreduras com tensão de polarização}

Para as varreduras de frequência usando tensão de polarização foram utilizadas tensões $C C$ de 0 a $153 \mathrm{~V}$ e a frequência do sinal CC de medição variou $1 \mathrm{kHz}$ a $1 \mathrm{MHz}$. As principais propriedades levantadas foram impedância, capacitância e ângulo de fase.

As curvas das figuras 8.18 a 8.20 mostram os resultados dessas medições para um protótipo com placas de alumínio com diâmetro de $1000 \mu \mathrm{m}$. Foi utilizada metade das placas desse CMUT. Nesta medição foram aplicadas tensões de polarização de 0 a $127 \mathrm{~V}$ aumentando-se o número de baterias. Como esta amostra tem placas muito grandes, pode ser danificada por tensões muito elevadas.

Como pode ser observado nos gráficos a capacitância aumenta com a tensão de polarização aplicada. A tendência das curvas de impedância é cair com a frequência e também com tensão de polarização. Isso indica que a placa flexível está sendo flexionada em direção ao eletrodo inferior. Em princípio, quanto maior a tensão de polarização, melhor para a operação do CMUT, entretanto, tensões muito elevadas danificam o dispositivo. Isso ocorre quando a tensão atinge o valor de colapso explicado na seção de modelagem. A força elástica da mola não é mais capaz de equilibrar-se com a força eletrostática, que adquire valor muito elevado. A placa é fletida até tocar o eletrodo inferior e há rompimento do dielétrico (fotorresiste AZ). A placa que sofre esse efeito estoura. Geralmente, o dispositivo não deixa de funcionar quando isso ocorre com poucas placas do array, mas tem suas propriedades dielétrica alteradas. Para CMUTs com placas maiores, esse efeito ocorre para menores tensões.

Utilizando uma amostra com placas menores (600 $\mu \mathrm{m}$ de diâmetro, foram levantadas curvas com tensões mais elevadas. Neste caso foi utilizado o 


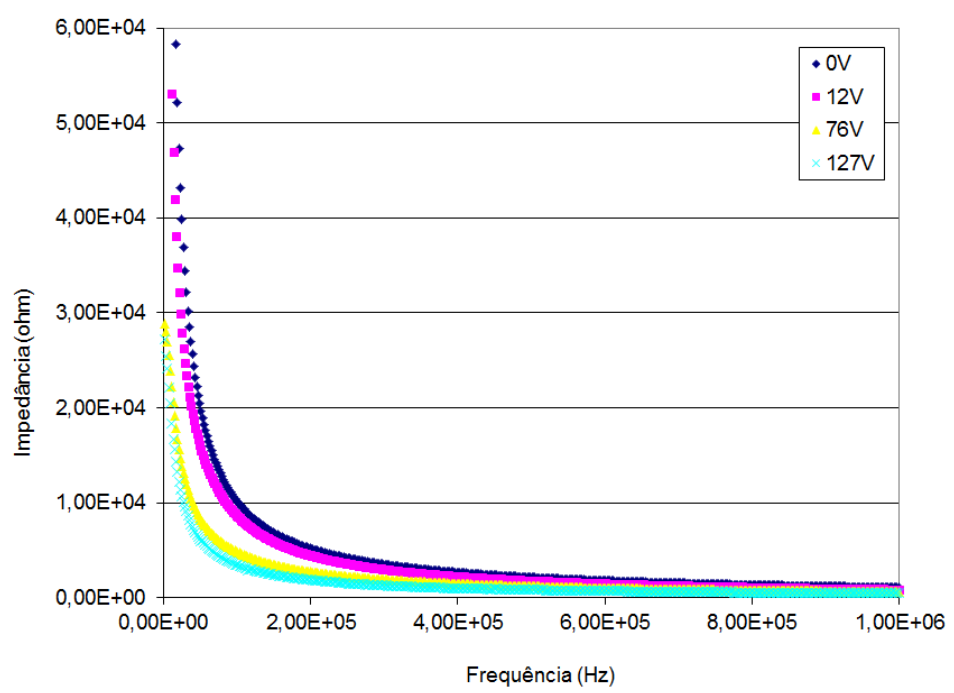

Figura 8.18: Curvas de impedância para meio arranjo de CMUTs com placas de alumínio de $1000 \mu \mathrm{m}$ de diâmetro.

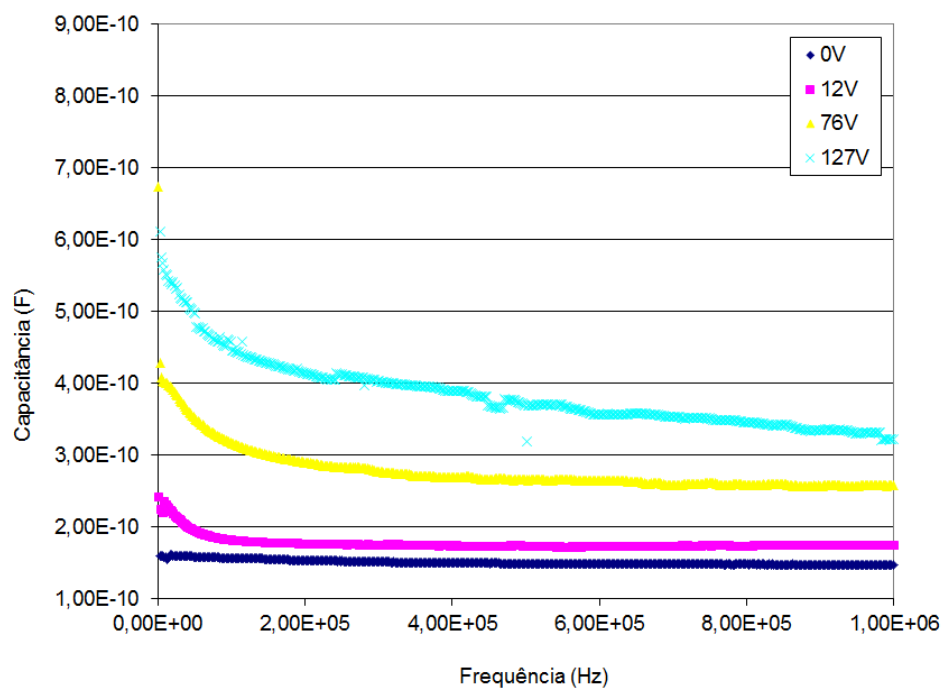

Figura 8.19: Curvas de capacitância para meio arranjo de CMUTs com placas de $1000 \mu \mathrm{m}$ de diâmetro. 


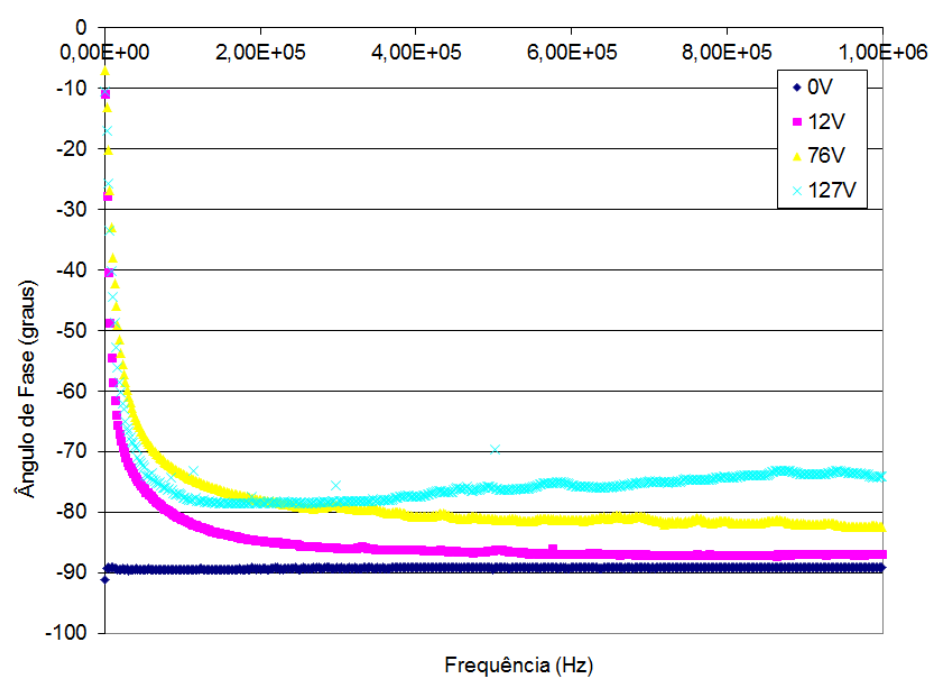

Figura 8.20: Curvas de ângulo de fase para meio arranjo de CMUTs com placas de alumínio de $1000 \mu \mathrm{m}$ de diâmetro.

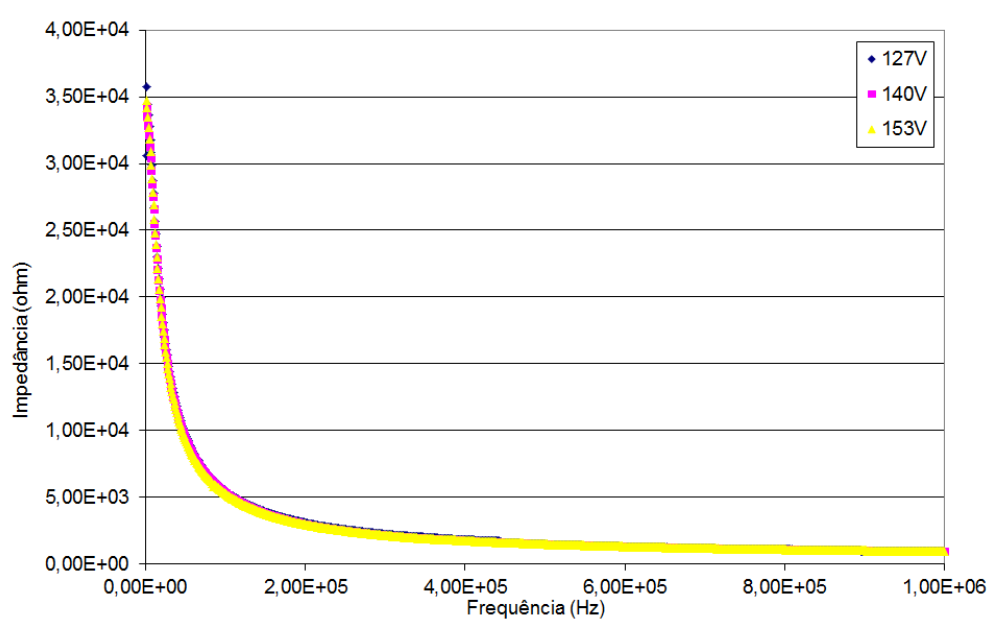

Figura 8.21: Curvas de impedância para arranjo inteiro de CMUTs com placas de alumínio de $600 \mu \mathrm{m}$ de diâmetro.

arranjo inteiro do CMUT (todas as placas do conjunto). Os resultados são mostrados nas figuras 8.21 a 8.23 .

O comportamento das curvas indicam que o CMUT opera melhor em baixas frequências. Nessa região o ângulo de fase tem módulo pequeno, indicando uma maior componente indutiva comparado a frequências mais elevadas. A componente indutiva indicada pelo comportamento das curvas a baixa frequência, se deve à massa da placa. Com uma polarização adequada, a placa é fletida ficando tencionada e a uma distância adequada do eletro inferior podendo responder a esta faixa de frequência. Sem uma polarização adequada, a placa não se aproxima o bastante do eletrodo inferior. Neste caso, não responde ao estímulo da sinal alternado devido à essa grande distância. Para o caso em que há polarização adequada, porém a frequência 


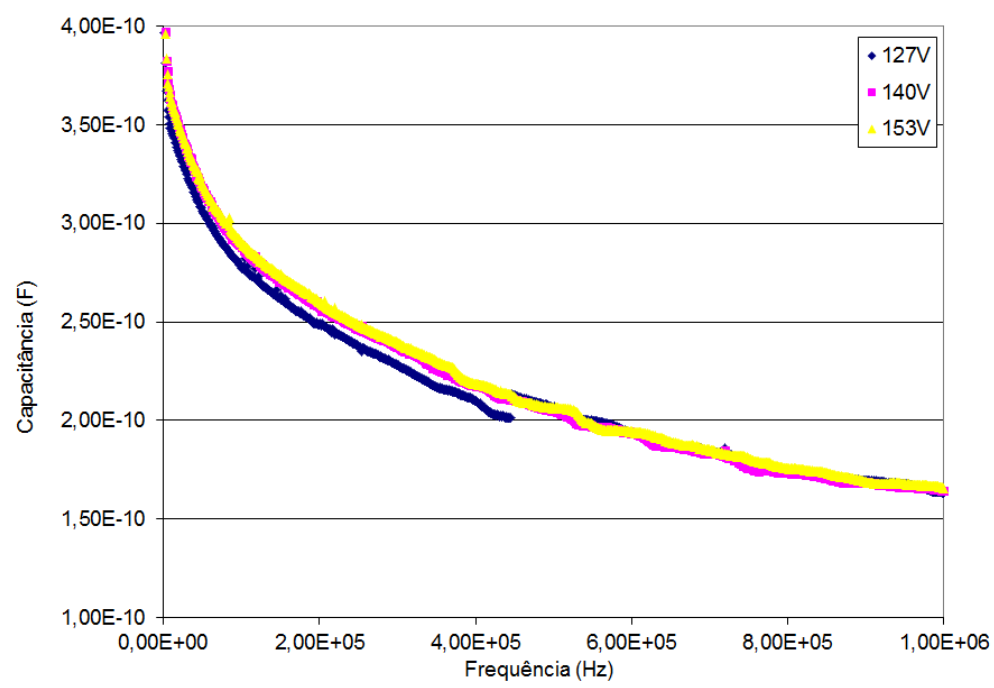

Figura 8.22: Curvas de capacitância para arranjo inteiro de CMUTs com placas de alumínio de $600 \mu \mathrm{m}$ de diâmetro.

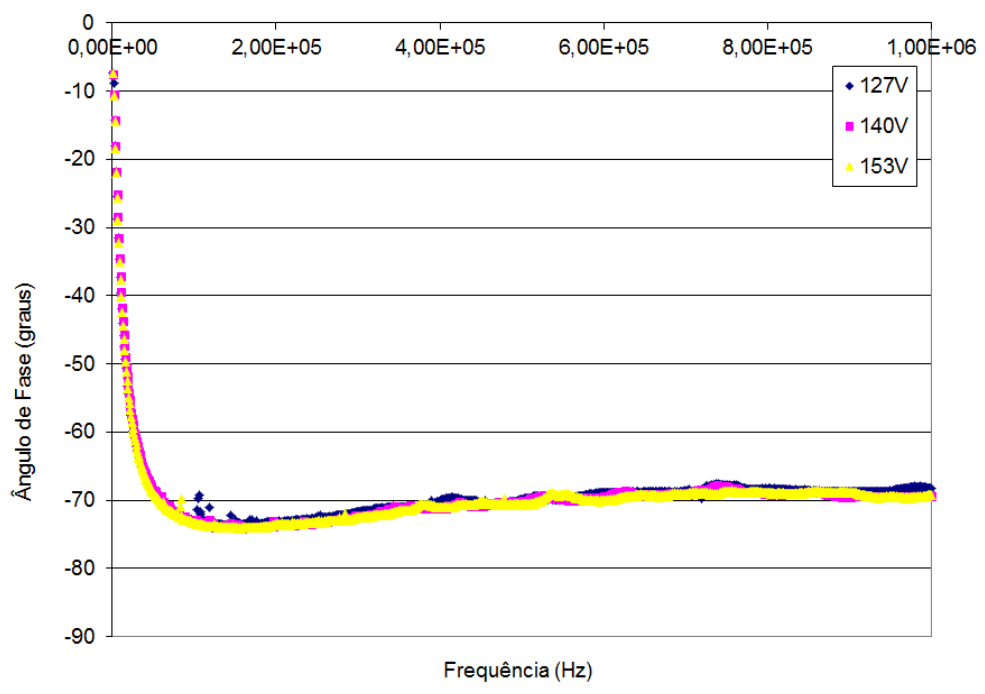

Figura 8.23: Curvas de ângulo de fase para arranjo inteiro de CMUTs com placas de alumínio de $600 \mu \mathrm{m}$ de diâmetro. 


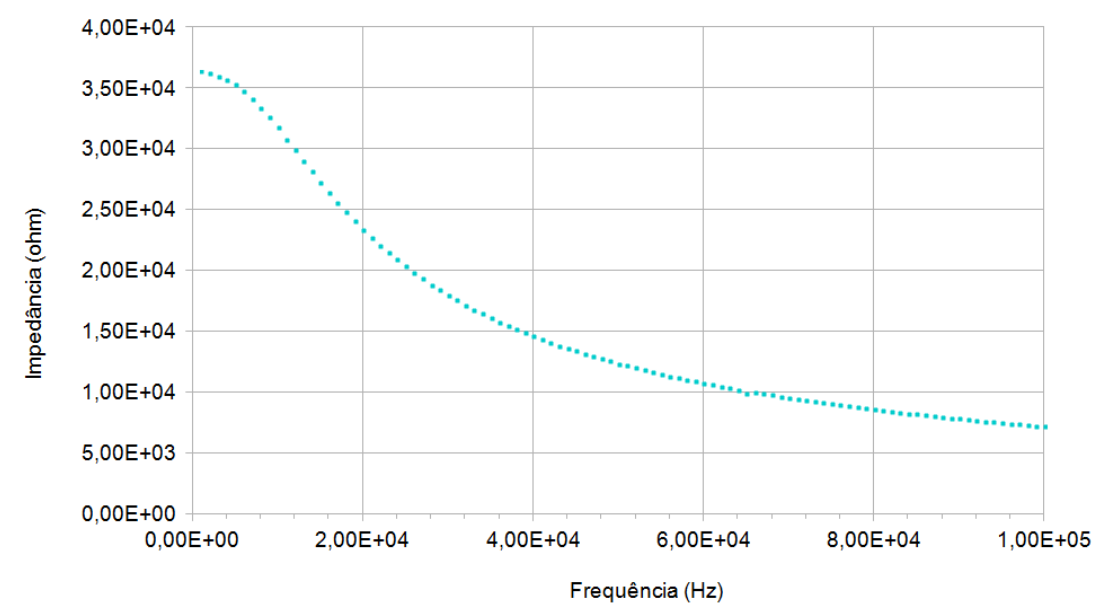

Figura 8.24: Curva de impedância para arranjo de CMUTs com placas de cobre de $500 \mu \mathrm{m}$ de diâmetro.

é muito elevada, novamente a placa não responde ao sinal alternado. Isso ocorre devido à inercia da placa, pois devido à sua massa, não há tempo hábil para que acompanhe o sinal alternado (cuja mudança de estado é muito rápida). Com isto, o dispositivo volta a apresentar comportamento essencialmente capacitivo.

Os resultados destas medições mostraram que tensões da ordem de 100 a 150 V são suficientes para polarizar CMUTs como membranas de alumínio com diâmetros de 600 a $1000 \mu \mathrm{m}$. Com isto o dispositivo pode operar como emissor ou receptor com segurança desde que sejam utilizados circuitos de proteção adequados.

As figuras 8.24 a 8.26 mostram resultados para varreduras das propriedades dielétricas em função da frequência em uma amostra de cobre. Neste CMUT, as placas têm $500 \mu \mathrm{m}$ de diâmetro e $30 \mu \mathrm{m}$ de espessura.

Nestes resultados, o comportamento das curvas indicam uma faixa de frequência ótima para a operação do dispositivo. Com a polarização adequada a placa do CMUT responde bem a frequências em torno de $15 \mathrm{kHz}$. Nesta região o dispositivo apresenta comportamento misto indutor-capacitor. Frequências mais elevadas não podem fazer vibrar a placa devido à sua inércia. 


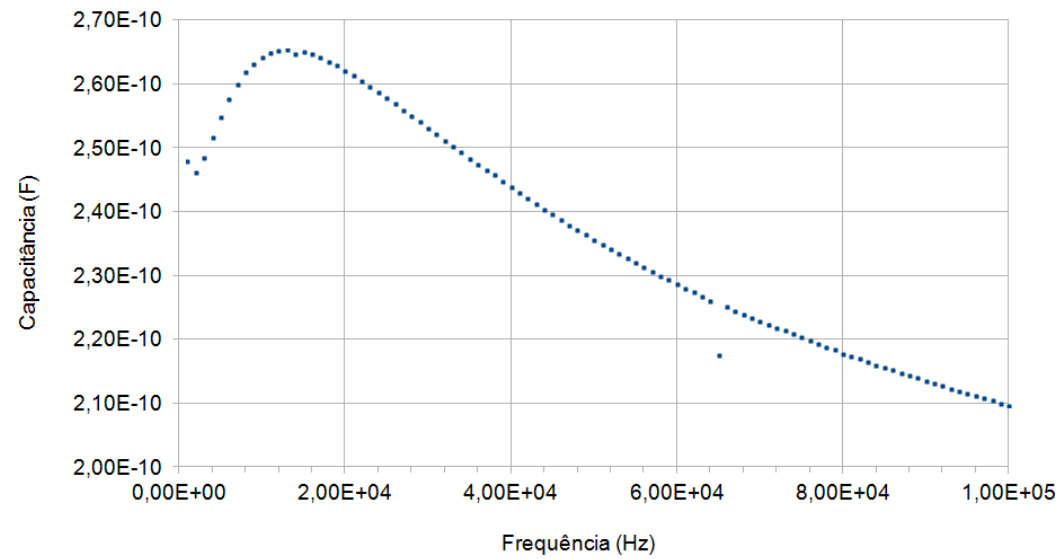

Figura 8.25: Curva de capacitância para arranjo de CMUTs com placas de cobre de $500 \mu \mathrm{m}$ de diâmetro.

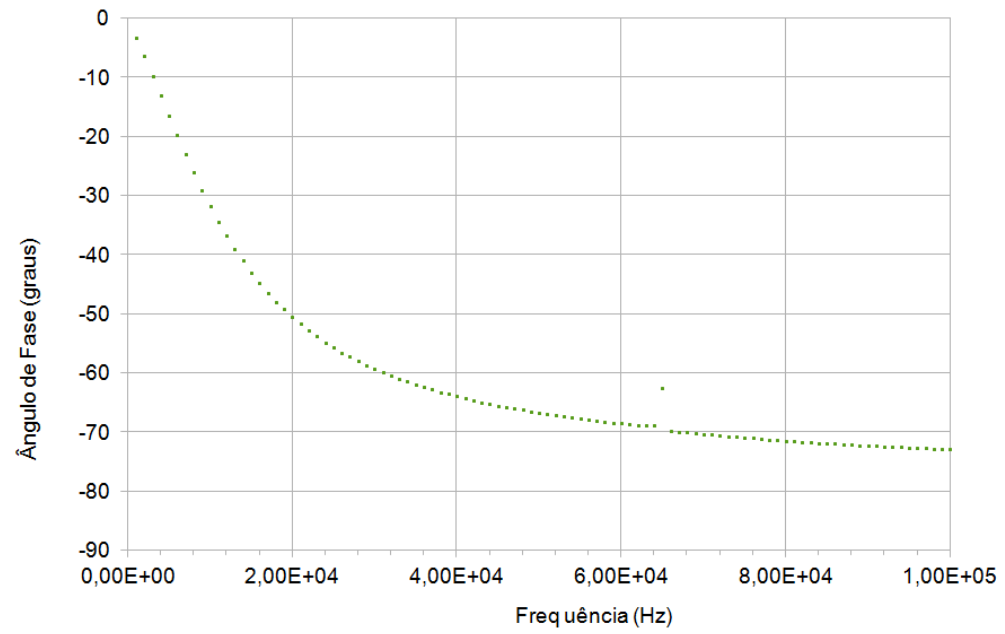

Figura 8.26: Curva de ângulo de fase para arranjo de CMUTs com placas de cobre de $500 \mu \mathrm{m}$ de diâmetro. 


\section{Conclusões}

Este trabalho apresentou técnicas de projeto, fabricação e caracterização de um micro-transdutor acústico capacitivo (CMUT). As simulações auxiliaram no melhor entendimento do funcionamento do dispositivo quando submetido a uma carga mecânica e também sob ação de uma tensão elétrica. Auxiliaram também na definição de parâmetros iniciais para a fabricação, como dimensões e materiais a serem utilizados.

O processo de fabricação, simplificado e de baixo custo se comparado a outros processos de fabricação de micro-transdutores, é a principal contribuição deste trabalho. Os protótipos foram fabricados utilizando-se recursos disponíveis no Brasil. Formam utilizados equipamentos mínimos de sala limpa e processos a baixas temperaturas. Foram necessárias algumas adaptações para adequar o processo às necessidades de fabricação do dispositivo em questão.

Os protótipos fabricados com placas de cobre têm cavidade de $5 \mu \mathrm{m}$ de profundidade. A placa tem espessura de $30 \mu \mathrm{m}$ e diâmetros de 800 e 1000 $\mu \mathrm{m}$. Os protótipos com placas de alumínio têm cavidades de $5 \mu \mathrm{m}$ e $0,5 \mu \mathrm{m}$ de profundidade. A placa tem espessura de $10 \mu \mathrm{m}$ e os diâmetros de 500 , 600,800 e $1000 \mu \mathrm{m}$. O alumínio se mostrou mais adequado pois o processo de fabricação utilizado permite obtenção de placas de menor espessura utilizando-se desse material. Durante etapas de caracterização elétrica, o dispositivo apresentou boas respostas na impedância e capacitância a ângulo de fase perante aplicação de forças mecânicas; tensão de polarização e tensão alternada sobre as placas.

Foram montados circuitos específicos para as caraterizações. Os mesmos permitiram simultaneamente, a aplicação de tensão de polarização e de um sinal alternado bem como a proteção de equipamentos de medição.

Utilizando-se baixas tensões de polarização o dispositivo tem comportamento típico de capacitor. Para polarizações mais altas, esse comportamento se altera aumentando a componente indutiva quando 
utilizado sinal alternado de baixa frequência. A componente indutiva se deve à massa da placa, que vibra conforme é excitada pelo sinal alternado. Uma vez que a polarização adequada tensiona a placa e a aproxima do eletrodo inferior, esta é capaz de acompanhar o sinal alternado a que é submetida. Esta faixa de frequência, em que o dispositivo apresenta um comportamento misto indutor-capacitor, é a melhor região, que ficou em torno de $15 \mathrm{kHz}$. Em frequências mais altas, a inércia da placa não permite acompanhar o sinal alternado e o dispositivo volta a ter comportamento essencialmente capacitivo.

Os protótipos do CMUT projetados, fabricados e testados demostram desempenho satisfatório para a funcionalidade proposta. Assim, o dispositivo apresenta bom potencial para aplicações envolvendo emissão e recepção de ondas acústicas como análise de fluidos. Os materiais e métodos utilizados permitem a fabricação em qualquer laboratório que possua uma alinhadora. A escolha do material e espessura da placa permitem a fabricação de protótipos para diferentes frequências de operação e diferentes aplicações. 


\section{Sugestões para Trabalhos Futuros}

Para trabalhos futuros algumas estratégias estão sendo pensadas e planejadas entre elas destacam-se as seguintes:

- Criar um sistema de vácuo que permita fazer a colagem das duas partes do CMUT em ambiente de baixa pressão. Com isso a cavidade ficaria selada a vácuo, o que impede que o ar dentro da cavidade limite 0 movimento da placa;

- Estudar meios de retomar a fabricação utilizando camada sacrificial. O que pode permitir a fabricação de amostras mais robustas e com placas mais finas;

- Estudar o uso de outros materiais para a fabricação da placa móvel;

- Estudar novas aplicações para o dispositivo explorando diferentes faixas de frequência de operação.

- Utilizar novas técnicas de caraterização incluindo imagens de holograma laser em laboratório da Faculdade de Tecnologia de São Paulo (FATEC-SP).

- Melhorar circuitos de medição utilizando amplificadores de instrumentação para reduzir os efeitos de ruídos e elevar o nível do sinal gerado pelo dispositivo no modo emissor. 


\section{Artigos publicados}

Durante a pesquisa relativa a esta tese foram publicados os seguintes trabalhos:

"ECS Transactions, 49 (1) 431-438 (2012)", ISSN: 1938-6737; The Electrochemical Society. OLIVEIRA, V. I. ; IBRAHIM, R. C. ; E. A. BARROS; TORIKAI, D. ; Lima, B. L. S. ; MENDONÇA, DIAS, L. G.; PIAZZETA, M. H. O. ; GOBBI, A. L. MEMS-Based Ultrasound Transducer: CMUT Modeling and Fabrication Process.

COBEM 2011 (ABCM Symposium Series in Mechatronics) OLIVEIRA, V. I. ; IBRAHIM, R. C. ; TORIKAI, D. ; Lima, B. L. S. ; MENDONÇA, Lucas Gonçalves Dias ; PIAZZETA, M. H. O. ; GOBBI, A. L. . Modeling, simulation and fabrication of a MEMS-based electrostatic capacitive effect-CMUT: For generation and reception of acoustic waves. In: COBEM 2011-21st Brazilian Congress of Mechanical Engineering, 2011, Natal-RN. Proceedings of the 21st International Congress of Mechanical Engineering, 2011. 


\section{Referências}

ALLEN, J. Micro electro mechanical system design. [S.I.]: CRC Press, 2005.

ANDERSON, M. J.; CHO, J. H.; RICHARDS, C. D.; BAHR, D. F.; RICHARDS, R. F. A comparison of piezoelectric and electrostatic electromechanical coupling for ultrasonic transduction and power generation. IEEE Ultrasonics Symposium 2005, p. 950-955, 2005.

BAYRAM, B.; HAEGGSTRöM, E.; YARALIOGLU, G. G.; KHURI-YAKUB, B. T. A new regime for operating capacitive micromachined ultrasonic transducers. IEEE transactions on ultrasonics, ferroelectrics, and frequency control, v. 50, n. 9, p. 1184-90, set. 2003. ISSN 0885-3010. Disponível em: $<$ http://www.ncbi.nlm.nih.gov/pubmed/14561034>.

BUHRDORF, a.; LOHFINK, a.; JUNGE, S.; ECCARDT, P.; BENECKE, W. Fabrication and characterization of a new capacitive micromachined ultrasonic transducer (cMUT) using polysilicon as membrane and sacrificial layer material. IEEE Symposium on Ultrasonics, 2003, leee, v. 00, n. c, p. 1951-1954, 2003. Disponível em:

$<$ http://ieeexplore.ieee.org/lpdocs/epic03/wrapper.htm?arnumber=1293299>.

CADY, W. G. Piezoelectricity. [S.I.]: Dover Publications Inc., 1964.

CALIANO, G.; CARONTI, a.; SAVOIA, a.; LONGO, C.; PAPPALARDO, M.; CIANCI, E.; FOGLIETTI, V. Capacitive micromachined ultrasonic transducer (cMUT) made by a novel reverse "fabrication process". IEEE Ultrasonics Symposium, 2005., leee, v. 00, n. c, p. 479-482, 2005.

CARONTI, A.; CALIANO, G.; CAROTENUTO, R.; SAVOIA, a.; PAPPALARDO, M.; CIANCI, E.; FOGLIETTI, V. Capacitive micromachined ultrasonic transducer (CMUT) arrays for medical imaging. Microelectronics Journal, v. 37, n. 8, p. 770-777, ago. 2006. ISSN 00262692.

CARONTI, A.; CALIANO, G.; SAVOIA, a.; PAPPALARDO, M. A low-noise, wideband electronic system for pulse-echo ultrasound imaging with cmut arrays. Ultrasonics Symposium, v. 3, p. 2219 - 2222, 2004.

CHANG, M. M.-W.; DENG, M. T.-M.; GWO, J. T.-J.; MAI, J. D.; HSU, E. Polymer-based Capacitive Micromachined Ultrasonic Transducers (CMUT) for Micro Surgical Imaging Applications. 2006 1st IEEE International Conference on Nano/Micro Engineered and Molecular Systems, leee, p. 61-65, jan. 2006.

CHIOU, D.-Y.; CHEN, M.-Y.; CHANG, M.-W.; DENG, H.-C. Characterization and Optimization Design of the Polymer-Based Capacitive Micro-Arrayed Ultrasonic Transducer. Japanese Journal of Applied Physics, v. 46, n. 11, p. 7496-7503, nov. 2007. ISSN 0021-4922. 
DEMIRCI, U.; ERGUN, A. S.; ORALKAN, O.; KARAMAN, M.; KHURI-YAKUB, B. T. Forward-viewing CMUT arrays for medical imaging. IEEE transactions on ultrasonics, ferroelectrics, and frequency control, v. 51, n. 7, p. 887-95, jul. 2004. ISSN 0885-3010.

ERGUN, A. S.; HUANG, Y.; ZHUANG, X.; ORALKAN, O.; YARAHOGLU, G. G.; KHURI-YAKUB, B. T. Capacitive micromachined ultrasonic transducers: Fabrication technology. IEEE transactions on ultrasonics, ferroelectrics, and frequency control, v. 52, n. 12, p. 2242-2258, 2005.

ERGUN, A. S.; YARALIOGLU, G. G.; KHURI-YAKUB, B. T. Capacitive micromachined ultrasonic transducers: Theory and Technology. Journal of Aerospace Engineering, n. April, p. 76-84, dez. 2003. ISSN 1874-9968.

FRANSSILA, S. Introcuction to Micro Fabrication. [S.I.]: John Wiley \& Sons, Ltd, 2004.

HALLER, M. I.; KHURI-YAKUB, B. T. A surface micromachined electrostatic ultrasonic air transducer. IEEE Ultrasonics Symposium, p. 1241-1244, 1994.

HUANG, Y.; HAEGGSTROM, E.; BAYRAM, B. Collapsed regime operation of capacitive micromachined ultrasonic transducers based on wafer-bonding technique. Ultrasonics, 2003, v. 2, n. c, p. 1161-1164, 2003.

HUNT, F. V. Electroacoustics: the Analysis of Transduction, and Its Historical Background. [S.I.]: Harvard Univ. Press, 1954.

IKEDA, T. Fundamentals of Piezoelectricity. [S.I.]: Oxford University Press, 1990.

JAFFE, B.; COOK, W. R. J.; JAFFE, H. Piezoelectric Ceramics. [S.I.]: Academic Press Inc., 1971.

JIN, X.; CHENG, C.; ORALKAN, O. Recent progress in capacitive micromachined ultrasonic immersion transducer arrays. Proc. of Eighth, 1999.

JUN, S.-H.; LEE, S.-M.; LEE, S.-H.; KIM, H.-E.; LEE, K.-W. Piezoelectric linear motor with unimorph structure by co-extrusion process. Sensors and Actuators A: Physical, v. 147, n. 1, p. 300-303, set. 2008. ISSN 09244247.

KNIGHT, J.; MCLEAN, J.; DEGERTEKIN, F. Low temperature fabrication of immersion capacitive micromachined ultrasonic transducers on silicon and dielectric substrates. IEEE Transactions on Ultrasonics, Ferroelectrics and Frequency Control, v. 51, n. 10, p. 1324-1333, out. 2004. ISSN 0885-3010.

LEE, H. J.; KUPNIK, M.; ORALKAN, O.; KHURI-YAKUB, B. T. Capacitive micromachined ultrasonic transducer as a chemical sensor. 2008 IEEE Sensors, leee, p. 5-8, out. 2008.

LEMPRIERE, B. M. Ultrasound and Elastic Waves Frequently Asked Questions. [S.I.]: Elsevier Inc., 2002.

MA, A. H.; TSANG, S.-h.; PARAMESWARAN, M.; LEUNG, A. M. Spin-on glass as a Sacrificial Layer for Patterned Metallization of Compliant SU-8 Microstructures. Processing, p. 288-291, 2007. 
MADOU, M. J. Fundamentals of Microfabrication the Science of Miniaturization. [S.I.]: CRC Press, 2002.

MENDONÇA, L. G. D. Micro-sensor Capacitivo para Avaliação da Qualidade de Combustíveis Automotivos. Dissertação (Mestrado) - Universidade de São Paulo, 2008.

OLIVEIRA, V. I.; IBRAHIM, R. C.; BARROS, E. A.; MENDONÇA, L. G. D.; LIMA, B. L. S.; GOBBI, M. H. O. P. A. L. Mems-based ultrasound transducer: Cmut modeling and fabrication process. ECS Transactions, v. 49, n. 1, p. 431-438, 2012.

OLIVEIRA, V. I.; IBRAHIM, R. C.; TORIKAI, D.; LIMA, B. L. S.; MENDONÇA, L. G. D.; ; GOBBI, M. H. O. P. A. L. Modeling, simulation and fabrication of a mems-based electrostatic capacitive effect ? cmut: for generation and reception of acoustic waves. Proceedings of the 21 st International Congress of Mechanical Engineering, 2011., 2011.

SAMEOTO, D.; TSANG, S.; PARAMESWARAN, M. Polymer MEMS processing for multi-user applications. Sensors and Actuators A: Physical, v. 134, n. 2, p. 457-464, mar. 2007. ISSN 09244247.

SHERMAN, J. L. B. C. H. Transducers and Arrays for Underwater Sound. [S.I.]: Springer New York, 2007.

THRÄNHARDT, M.; ECCARDT, P. A resonant CMUT sensor for fluid applications. IEEE Sensors 2009 Conference, p. 878-883, 2009. Disponível em: <http://ieeexplore.ieee.org/xpls/abs_all.jsp?arnumber=5398234>.

THRÄNHARDT, M.; ECCARDT, P.-C.; MOOSHOFER, H.; HAUPTMANN, P. A resonant CMUT-based fluid sensor: Modeling and simulation. Sensors and Actuators A: Physical, v. 156, n. 1, p. 191-195, nov. 2009. ISSN 09244247. Disponível em: $<$ http://linkinghub.elsevier.com/retrieve/pii/S0924424709001800>.

TIMOSHENKO, S.; WOINOWSKY-KRIEGER, S. Theory of Plates and Shells. [S.I.]: McGraw-Hill Book Co, 1959.

TÖRNDAHL, M.; AL et. Characterisation and comparison of a cmut versus a piezoelectric transducer for air applications. IEEE Ultrasonics Symposium 2002, p. 1023-1026, 2002.

YOUNG, W. C.; BUDYNAS, R. G. Roark's formulas for stess and Strain. [S.I.]: McGraw-Hill, 2002.

ZHUANG, X.; MEMBER, S.; WYGANT, I. Wafer-Bonded 2-D CMUT Arrays Interconnects with a Supporting Frame. October, v. 56, n. 1, p. 182-192, 2009. 